\title{
GREET 1.0 - Transportation Fuel Cycles Model: Methodology and Use
}

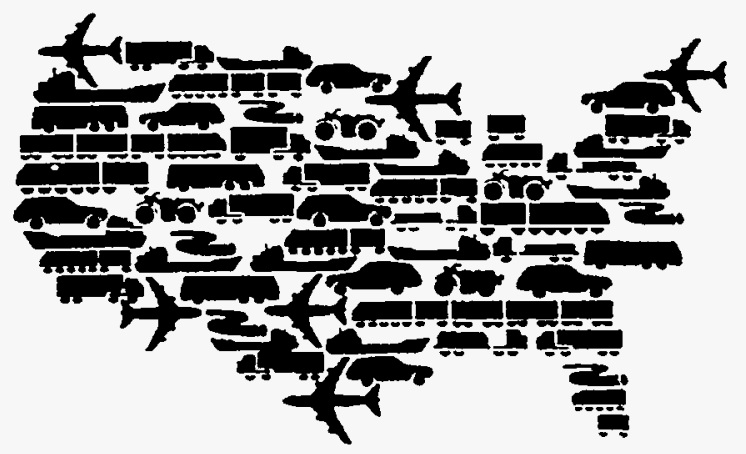

Center for Transportation Research Argonne National Laboratory 


\section{Argonne National Laboratory}

Argonne National Laboratory, with facilities in the states of Illinois and Idaho, is owned by the United States Govemment, and operated by the University of Chicago under the provisions of a contract with the Department of Energy.

This technical report is a product of Argonne's Energy Systems Division.

For information on the division's scientific and engineering activities, contact:

Director, Energy Systems Division

Argonne National Laboratory

Argonne, Illinois 60439-4815

Telephone (708) 252-3724

Publishing support services were provided by Argonne's information and Publishing Division (for more information, see IPD's home page: http://www.ipd.anl.gov/).

\section{Disclaimer}

This report was prepared as an account of work sponsored by an agency of the United States Government. Neither the United States Government nor any agency thereof, nor any of their employees, makes any warranty, express or implied, or assumes any legal liability or responsibility for the accuracy, completeness, or usefulness of any information, apparatus, product, or process disclosed, or represents that its use would not infringe privately owned rights. Reference herein to any specific commercial product, process, or service by trade name, trademark, manufacturer, or otherwise, does not necessarily constitute or imply its endorsement, recommendation, or favoring by the United States Government or any agency thereof. The views and opinions of authors expressed herein do not necessarily state or reflect those of the United States Government or any agency thereof. 


\section{GREET 1.0 - Transportation Fuel Cycles Model: Methodology and Use}

by M.Q. Wang

Center for Transportation Research, Energy Systems Division,

Argonne National Laboratory, 9700 South Cass Avenue, Argonne, Illinois 60439

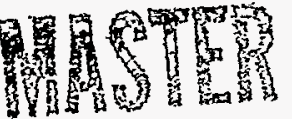

\section{DISTRIBUTION OF THIS DOCUMENT IS UNLAMTTED \& $\mathrm{S}$}

June 1996

GREET - Greenhouse Gases, Regulated Emissions, and Energy Use in Transportation

Work sponsored by the United States Department of Energy, Assistant Secretary for Energy Efficiency and Renewable Energy, Office of Transportation Technologies 
This report is printed on recycled paper. 


\section{DISCLAIMER}

Portions of this document may be illegible in electronic image products. Images are produced from the best available original document. 



\section{NOTICE}

A previous report, prepared for the Office of Transportation Technologies, U.S. Department of Energy, and entitled Criteria Pollutant, Greenhouse Gas, and Energy Model for Transportation Fuel Cycles, documented an earlier version of the fuel-cycle emissions and energyuse model developed at Argonne National Laboratory. The original version of the model, called the Criteria Pollutant, Greenhouse Gas, and Energy Model (CPGEM), relied on emission factors contained in the fourth edition (with various supplements) of the U.S. Environmental Protection Agency's (EPA's) AP-42 document. In 1995, EPA released the fifth edition of the AP-42 document. Argonne updated the model to reflect the emission factors contained in the fifth edition. The updated model was renamed the Greenhouse Gases, Regulated Emissions, and Energy Use in Transportation (GREET) model. Additional features of the model include calculation of fossil fuel consumption, total energy consumption, and petroleum consumption; and calculation of both all-location and inbasin emissions for volatile organic compounds, carbon monoxide, nitrogen oxides, particulate matter measuring 10 microns $(\mu \mathrm{m})$ or less, and sulfur oxides.

The updated model was described in a report issued in March 1996, entitled Development and Use of the GREET Model to Estimate Fuel-Cycle Energy Use and Emissions of Various Transportation Technologies and Fuels. The report was revised slightly in June 1996 and retitled GREET 1.0-Transportation Fuel Cycles Model: Methodology and Use. 


\section{CONTENTS}

NOTATION $\ldots \ldots \ldots \ldots \ldots \ldots \ldots \ldots \ldots \ldots \ldots \ldots \ldots \ldots \ldots \ldots \ldots \ldots \ldots$ viii

ACKNOWLEDGMENTS $\ldots \ldots \ldots \ldots \ldots \ldots \ldots \ldots \ldots \ldots \ldots \ldots \ldots \ldots \ldots \ldots$

ABSTRACT $\ldots \ldots \ldots \ldots \ldots \ldots \ldots \ldots \ldots \ldots \ldots \ldots \ldots \ldots \ldots \ldots \ldots \ldots \ldots$

1 INTRODUCTION $\ldots \ldots \ldots \ldots \ldots \ldots \ldots \ldots \ldots \ldots \ldots \ldots \ldots \ldots \ldots \ldots \ldots \ldots$

2 REVIEW OF PREVIOUS FUEL-CYCLE STUDIES $\ldots \ldots \ldots \ldots \ldots \ldots \ldots \ldots$

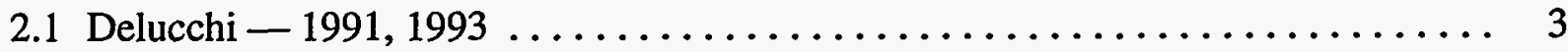

2.2 National Renewable Energy Laboratory et al. $-1991,1992 \ldots \ldots \ldots \ldots \ldots \ldots 4$

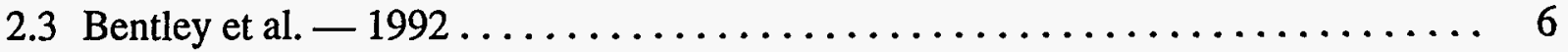

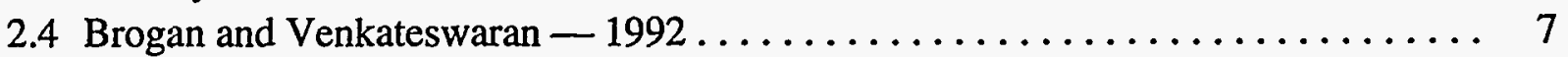

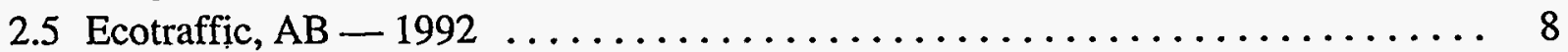

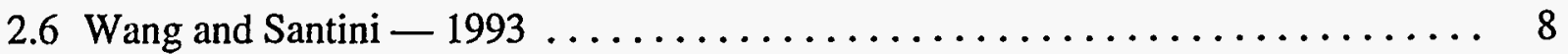

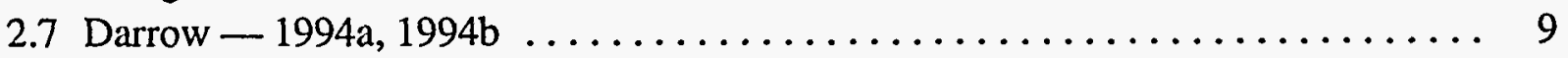

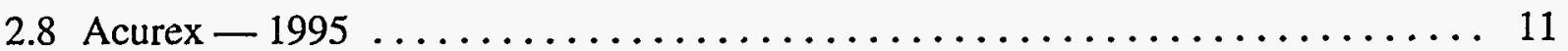

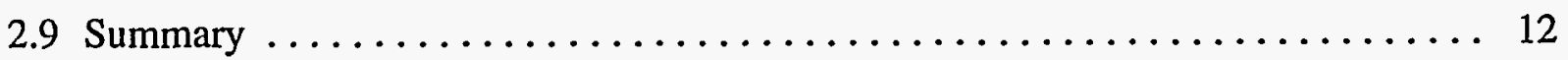

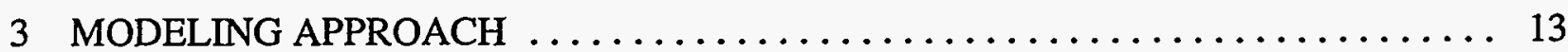

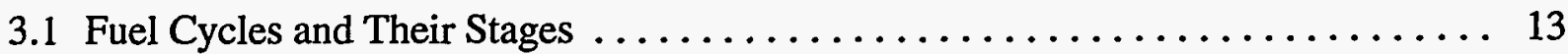

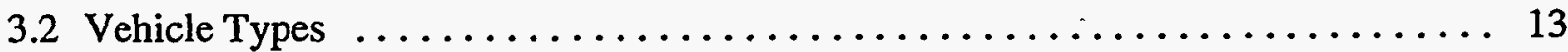

3.3 Calculation of Energy Use during a Fuel-Cycle Stage $\ldots \ldots \ldots \ldots \ldots \ldots \ldots 13$

3.4 Calculation of Emissions for Each Fuel-Cycle Stage $\ldots \ldots \ldots \ldots \ldots \ldots \ldots$

4 CALCULATION OF FUEL-CYCLE EMISSIONS AND ENERGY USE $\ldots \ldots \ldots \ldots 20$

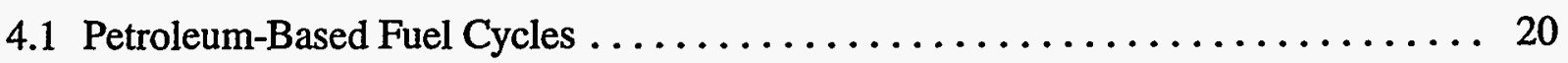

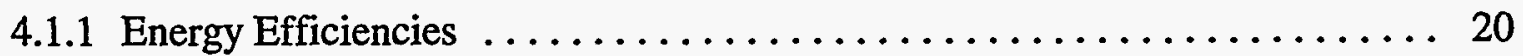

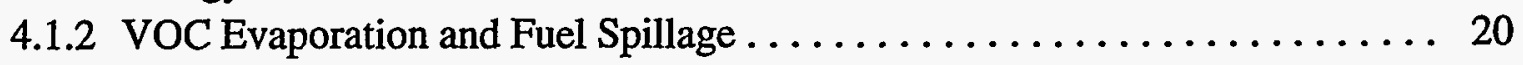

4.1.3 Noncombustion Emissions at Refineries ................... 21

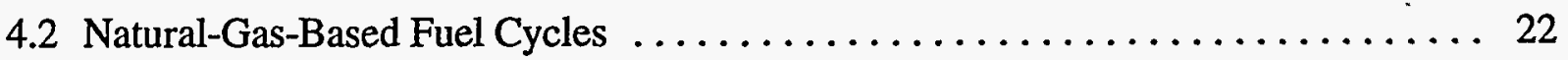

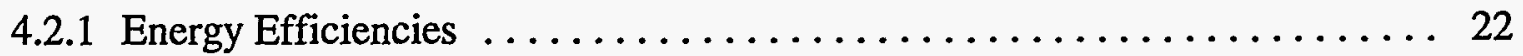

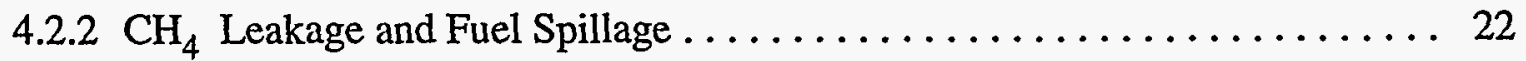

4.2.3 Noncombustion Emissions during Natural Gas Processing and Fuel Production . . . . . . . . . . . . . . . . . . . . . . . 24 


\section{CONTENTS (Cont.)}

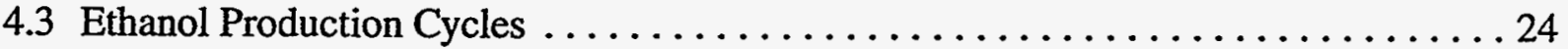

4.3.1 Fuel and Fertilizer Use for Corn and Biomass Production $\ldots \ldots \ldots \ldots \ldots 25$

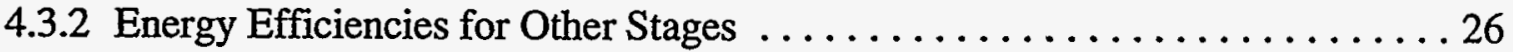

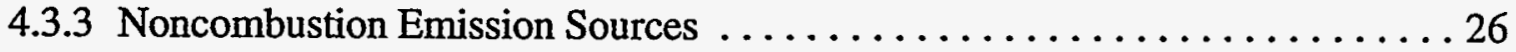

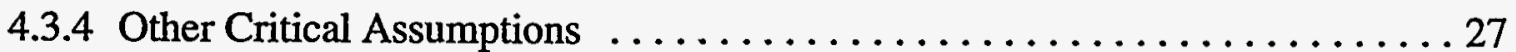

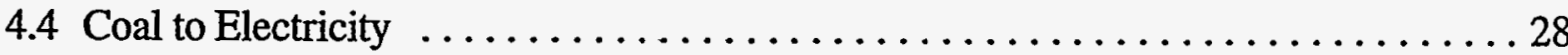

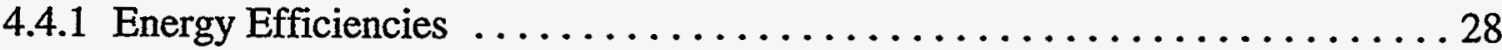

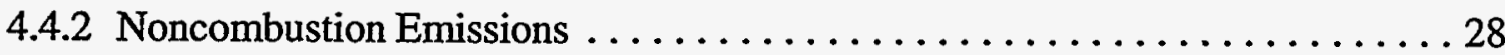

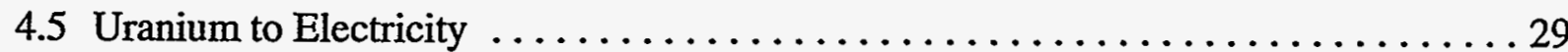

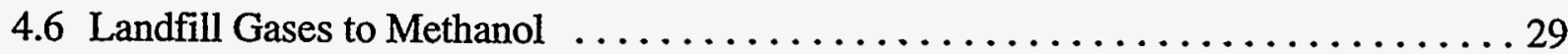

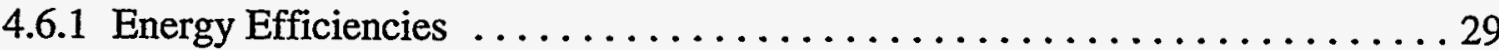

4.6.2 Emission Credits of Methanol Production . . . . . . . . . . . . . . . 29

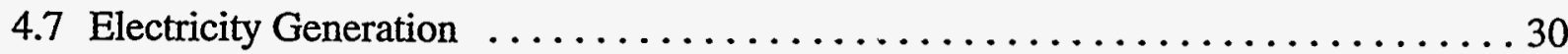

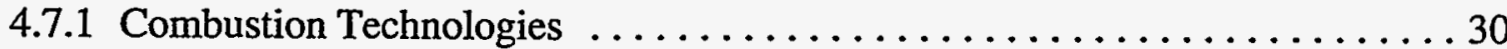

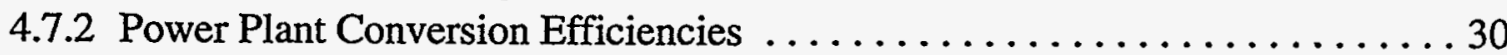

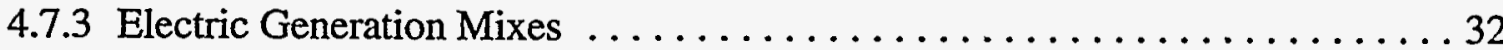

4.8 Vehicle Operations . . . . . . . . . . . . . . . . . . . . . . . . 32

4.8.1 Vehicle Fuel Economy and Component Efficiencies $\ldots \ldots \ldots \ldots \ldots \ldots 32$

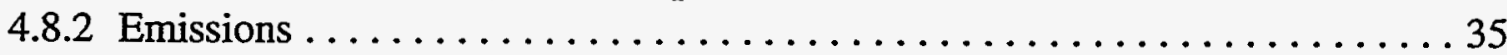

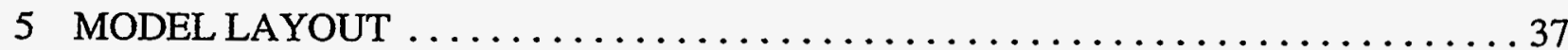

6 ENERGY USE AND EMISSIONS RESULTS $\ldots \ldots \ldots \ldots \ldots \ldots \ldots \ldots \ldots \ldots \ldots \ldots \ldots$

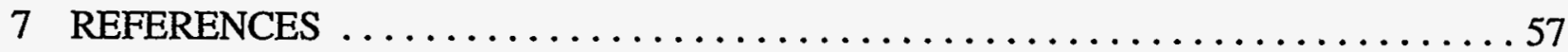

APPENDIX: CHANGES IN ENERGY USE AND EMISSIONS

BY ALTERNATIVE FUELS $\ldots \ldots \ldots \ldots \ldots \ldots \ldots \ldots \ldots \ldots \ldots \ldots \ldots \ldots \ldots$

\section{TABLES}

1 Fuel Cycles Included in the GREET Model $\ldots \ldots \ldots \ldots \ldots \ldots \ldots \ldots \ldots$

2 Energy Efficiencies of Petroleum-Based Fuel-Cycle Stages $\ldots \ldots \ldots \ldots \ldots \ldots \ldots$

3 Energy Efficiencies of Natural-Gas-Based Fuel-Cycle Stages $\ldots \ldots \ldots \ldots \ldots \ldots \ldots$ 


\section{TABLES (Cont.)}

4 Fuel and Fertilizer Usage for Production and Transportation of Corn and Biomass . . . . 25

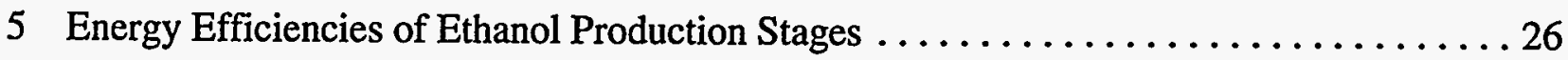

6 Energy Conversion Efficiencies of Electric Power Plants $\ldots \ldots \ldots \ldots \ldots \ldots \ldots \ldots$

7 Electric Generation Mix of Various U.S. Regions in $2005 \ldots \ldots \ldots \ldots \ldots \ldots$

8 Fuel Economy Improvements of 11 Vehicle Types $\ldots \ldots \ldots \ldots \ldots \ldots \ldots \ldots \ldots \ldots \ldots \ldots \ldots \ldots$

9 Emission Changes of Vehicle Operations for Various Vehicle Types $\ldots \ldots \ldots \ldots \ldots 36$

10 Fuel-Cycle Energy Use and Emissions of a 2000 Model Year Car in $2005 \ldots \ldots \ldots \ldots 41$

\section{FIGURES}

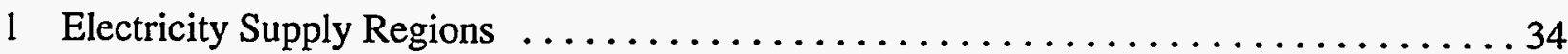

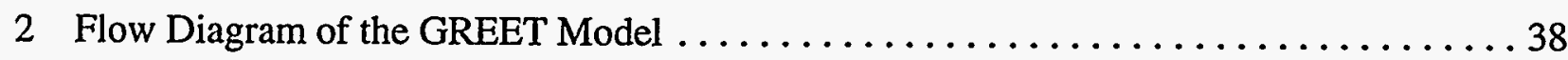

3 Calculation Logic of Upstream Emissions and Energy Use in the GREET Model . . . . . . 39

4 Change in Fuel-Cycle Total Energy Use $\ldots \ldots \ldots \ldots \ldots \ldots \ldots \ldots \ldots \ldots$

5 Change in Fuel-Cycle Fossil Fuel Use $\ldots \ldots \ldots \ldots \ldots \ldots \ldots \ldots \ldots \ldots \ldots \ldots \ldots \ldots \ldots \ldots \ldots \ldots$

6 Change in Fuel-Cycle Petroleum Use $\ldots \ldots \ldots \ldots \ldots \ldots \ldots \ldots \ldots \ldots$

7 Change in Fuel-Cycle VOC Emissions $\ldots \ldots \ldots \ldots \ldots \ldots \ldots \ldots \ldots . \ldots \ldots$

8 Change in Fuel-Cycle CO Emissions $\ldots \ldots \ldots \ldots \ldots \ldots \ldots \ldots \ldots \ldots \ldots \ldots \ldots \ldots \ldots \ldots \ldots \ldots \ldots \ldots$

9 Change in Fuel-Cycle $\mathrm{NO}_{\mathrm{x}}$ Emissions $\ldots \ldots \ldots \ldots \ldots \ldots \ldots \ldots \ldots \ldots \ldots \ldots \ldots \ldots \ldots \ldots \ldots \ldots$

10 Change in Fuel-Cycle $\mathrm{PM}_{10}$ Emissions $\ldots \ldots \ldots \ldots \ldots \ldots \ldots \ldots \ldots \ldots \ldots \ldots \ldots \ldots \ldots \ldots \ldots \ldots$

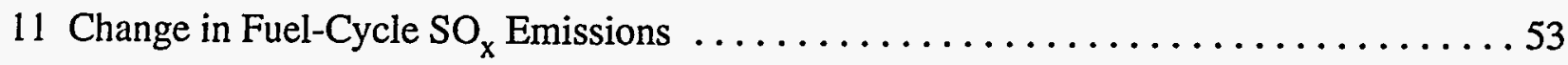

12 Change in Fuel-Cycle Greenhouse Gas Emissions ..................... 54 


\section{NOTATION}

\section{ACRONYMS AND ABBREVIATIONS}

\begin{tabular}{|c|c|}
\hline AFV & alternative-fuel vehicle \\
\hline CARB & California Air Resources Board \\
\hline $\mathrm{CH}_{4}$ & methane \\
\hline CNG & compressed natural gas \\
\hline CNGV & compressed natural gas vehicle \\
\hline $\mathrm{CO}$ & carbon monoxide \\
\hline $\mathrm{CO}_{2}$ & carbon dioxide \\
\hline CPGEM & Criteria Pollutant, Greenhouse Gas, and Energy Model \\
\hline EIA & Energy Information Administration \\
\hline EPA & U.S. Environmental Protection Agency \\
\hline ETAE & ethyl tertiary amyl ether \\
\hline ETBE & ethyl tertiary butyl ether \\
\hline EV & electric vehicle \\
\hline E10 & mixture of $10 \%$ ethanol and $90 \%$ gasoline (by volume) \\
\hline E85 & mixture of $85 \%$ ethanol and $15 \%$ gasoline (by volume) \\
\hline E95 & mixture of $95 \%$ ethanol and $5 \%$ gasoline (by volume) \\
\hline E100 & neat ethanol \\
\hline FCV & fuel-cell vehicle \\
\hline GHG & greenhouse gas \\
\hline GREET & Greenhouse Gases, Regulated Emissions, and Energy Use in Transportation \\
\hline GRI & Gas Research Institute \\
\hline GV & gasoline vehicle \\
\hline GWP & global warming potential \\
\hline $\mathrm{HC}$ & hydrocarbon \\
\hline HEV & hybrid electric vehicle \\
\hline ICEV & internal combustion engine vehicles \\
\hline INEL & Idaho National Engineering Laboratory \\
\hline IPCC & Intergovernmental Panel on Climate Change \\
\hline LNG & liquefied natural gas \\
\hline LPG & liquefied petroleum gas \\
\hline LSD & low-sulfur diesel \\
\hline MSW & municipal solid wastes \\
\hline MTBE & methyl tertiary butyl ether \\
\hline MY & model year \\
\hline M85 & mixture of $85 \%$ methanol and $15 \%$ gasoline (by volume) \\
\hline M100 & neat methanol \\
\hline $\mathrm{Na} / \mathrm{S}$ & sodium/sulfur \\
\hline
\end{tabular}




$\begin{array}{ll}\mathrm{NG} & \text { natural gas } \\ \mathrm{NMOG} & \text { nonmethane organic gases } \\ \mathrm{NO}_{x} & \text { nitrogen oxides } \\ \mathrm{N}_{2} \mathrm{O} & \text { nitrous oxide } \\ \mathrm{NREL} & \text { National Renewable Energy Laboratory } \\ \mathrm{PM} & \text { particulate matter } \\ \mathrm{PM} & \text { particulate matter measuring } 10 \text { microns or less } \\ \mathrm{RFG} & \text { reformulated gasoline } \\ \mathrm{ROG} & \text { reactive organic gas } \\ \mathrm{SCAQMD} & \text { South Coast Air Quality Management District } \\ \mathrm{SO} & \text { sulfur oxides } \\ \mathrm{SO} & \text { sulfur dioxide } \\ \mathrm{TAME} & \text { tertiary amyl methyl ether } \\ \text { T\&D } & \text { transportation and distribution } \\ \mathrm{T} \& \mathrm{~S} & \text { transportation and storage } \\ \text { T\&S\&D } & \text { transportation, storage, and distribution } \\ \text { VMT } & \text { vehicle miles traveled } \\ \text { VOC } & \text { volatile organic compound }\end{array}$

\section{UNITS OF MEASURE}

Btu British thermal unit

Btu/mi Btu per mile

$\mathrm{Btu} / 10^{6} \mathrm{Btu}$ Btu per million Btu

$\mathrm{g} / 10^{6} \mathrm{Btu} \quad$ grams per million Btu

$\mathrm{g} / \mathrm{gal}$ grams per gallon

$\mathrm{g} / \mathrm{mi} \quad$ grams per mile

$\mathrm{kWh} \quad$ kilowatt hours

MPG miles per gallon 


\section{ACKNOWLEDGMENTS}

This work was sponsored by the U.S. Department of Energy, Assistant Secretary for Energy Efficiency and Renewable Energy, Office of Transportation Technologies, under contract W-31-109-Eng-38. Earlier efforts for this project were sponsored by the Office of Technology Assessment, U.S. Congress. The author sincerely thanks Phillip Patterson of the Office of Transportation Technologies, U.S. Department of Energy; Steven Plotkin of Argonne National Laboratory (previously of the Office of Technology Assessment, U.S. Congress); and Danilo Santini of Argonne National Laboratory for their helpful comments and suggestions. The author is grateful for comments from Steven Bernow of Tellus Institute; Mark A. Delucchi of the University of California at Davis; Peter Reilly-Roe of Natural Resources Canada; Velu Senthil of the Energy Information Administration, U.S. Department of Energy; and Murray Ward of BC Environment, Canada. However, the author is solely responsible for the results of this work. 


\title{
DEVELOPMENT AND USE OF THE GREET MODEL TO ESTIMATE FUEL-CYCLE ENERGY USE AND EMISSIONS OF VARIOUS TRANSPORTATION TECHNOLOGIES AND FUELS
}

by

\author{
Michael Q. Wang
}

\begin{abstract}
This report documents the development and use of the Greenhouse Gases, Regulated Emissions, and Energy Use in Transportation (GREET) model. The model, developed in a spreadsheet format, estimates the full fuel-cycle emissions and energy use associated with various transportation fuels for lightduty vehicles. The model calculates fuel-cycle emissions of five criteria pollutants (volatile organic compounds, carbon monoxide, nitrogen oxides, sulfur oxides, and particulate matter measuring 10 microns or less) and three greenhouse gases (carbon dioxide, methane, and nitrous oxide). The model also calculates the total fuel-cycle energy consumption, fossil fuel consumption, and petroleum consumption using various transportation fuels. The GREET model includes 17 fuel cycles: petroleum to conventional gasoline, reformulated gasoline, clean diesel, liquefied petroleum gas, and electricity via residual oil; natural gas to compressed natural gas, liquefied petroleum gas, methanol, hydrogen, and electricity; coal to electricity; uranium to electricity; renewable energy (hydropower, solar energy, and wind) to electricity; corn, woody biomass, and herbaceous biomass to ethanol; and landfill gases to methanol. This report presents fuel-cycle energy use and emissions for a 2000 model-year car powered by each of the fuels that are produced from the primary energy sources considered in the study.
\end{abstract}

\section{INTRODUCTION}

Transportation technologies - powered by various transportation fuels - are being promoted to help solve urban air pollution problems, limit climate change impacts caused by greenhouse gas (GHG) emissions, and reduce U.S. dependence on imported oil. To completely evaluate the energy and emission effects of these transportation technologies, one must consider emissions and energy use from upstream fuel production processes as well as from vehicle operations. This is especially important for technologies that employ fuels with distinctly different 
primary energy sources and fuel production processes, for which upstream emissions and energy use can be significantly different.

Various studies have been conducted to estimate fuel-cycle emissions and energy use for various transportation technologies; the estimates developed by researchers are subject to assumptions regarding technology development, emission controls, primary fuel sources, fuel production processes, and many other factors. Tools for calculating emissions and energy use are needed to test the effects of these assumptions on fuel-cycle emissions. Comprehensive tools to compare the fuel-cycle emissions and energy use of various technologies and to conduct sensitivity analyses of various assumptions are rarely available. It is difficult, then, to compare and reconcile the results of different studies and to conduct a comprehensive evaluation of fuel-cycle emissions and energy use.

This report describes the development of a fuel-cycle model called the Greenhouse Gases, Regulated Emissions, and Energy Use in Transportation (GREET) model. The model calculates, for a given fuel/transportation technology combination, the fuel-cycle emissions of five criteria pollutants - volatile organic compounds (VOC), carbon monoxide (CO), nitrogen oxides $\left(\mathrm{NO}_{\mathrm{x}}\right)$, sulfur oxides $\left(\mathrm{SO}_{\mathrm{x}}\right)$, and particulate matter measuring 10 microns or less $\left(\mathrm{PM}_{10}\right)$ - and three greenhouse gases - carbon dioxide $\left(\mathrm{CO}_{2}\right)$, methane $\left(\mathrm{CH}_{4}\right)$, and nitrous oxide $\left(\mathrm{N}_{2} \mathrm{O}\right)$. The GREET model also calculates total fuel-cycle energy consumption, fossil fuel consumption, and petroleum consumption according to the fuel/transportation technology combination. The model can be used both to compare the fuel-cycle emissions and energy use of various transportation technologies and to test the emission and energy effects of the various assumptions used to estimate emissions and energy use. Our report presents the fuel-cycle emissions and energy use of various transportation technologies, as calculated by using the GREET model. 


\section{REVIEW OF PREVIOUS FUEL-CYCLE STUDIES}

This section describes the methods and assumptions used in previous studies conducted to estimate fuel-cycle emissions and energy use.

\subsection{DELUCCHI - 1991, 1993}

Delucchi conducted a study to estimate fuel-cycle emissions of GHGs for various transportation fuels and for electricity generation (Delucchi 1991; 1993). The GHGs considered in the study included $\mathrm{CO}_{2}, \mathrm{CH}_{4}, \mathrm{CO}, \mathrm{N}_{2} \mathrm{O}, \mathrm{NO}_{\mathrm{x}}$, and nonmethane organic gases (NMOG). Besides emissions and energy use of fuel-cycle stages ranging from primary energy recovery to on-vehicle fuel combustion, Delucchi examined the emissions and energy use involved in the manufacture of motor vehicles, maintenance of transportation systems, manufacture of materials used in major energy facilities, and changes in land use caused by the production of biofuels. Through his study, Delucchi developed a model of calculating GHG emissions. The model included the following fuel cycles: petroleum to gasoline, petroleum to diesel, petroleum to liquefied petroleum gas (LPG), natural gas (NG) to methanol, NG to compressed natural gas (CNG), NG to liquefied natural gas (LNG), NG to LPG, coal to methanol, wood to methanol, corn to ethanol, wood to ethanol, nuclear energy to hydrogen, solar energy to hydrogen, and electricity generation from various fuels.

To calculate GHG emissions for a specific fuel-cycle stage, Delucchi first estimated the total amount of energy burned at that stage. He allocated the total amount of energy to different fuels (e.g., residual oil, NG, electricity, coal), then estimated combustion-causing emissions of GHGs (except $\mathrm{CO}_{2}$ ) by using emission factors. He calculated $\mathrm{CO}_{2}$ emissions by using a carbon balance approach: the carbon contained in $\mathrm{CO}, \mathrm{CH}_{4}$, and $\mathrm{NMOG}$ emissions was subtracted from all available carbon in a combusted fuel, and the remaining carbon was assumed to be oxidized to $\mathrm{CO}_{2}$. Besides combustion-causing emissions, Delucchi included GHG emissions from fuel losses such as leakage and evaporation. He combined emissions of all GHGs together with their global warming potentials (GWPs) and presented the results of fuel-cycle, vehicle life-cycle GHG emissions in $\mathrm{CO}_{2}$ equivalent emissions per mile of travel.

To derive process energy efficiencies and energy source shares for total energy consumption, Delucchi relied primarily on a 1985 Energy Information Administration (EIA) survey on manufacturing energy consumption. Delucchi estimated the emission factors of various energy combustion processes primarily on the basis of information in the fourth edition of the U.S. Environmental Protection Agency (EPA) AP-42 document.

Using his model, Delucchi estimated GHG emissions for the year 2000 from a baseline gasoline car with a fuel economy of 30 miles per gallon (MPG). He generally assumed 
improvements in energy efficiency for alternative-fuel vehicles (AFVs) relative to gasoline vehicles (GVs). To address uncertainties in future energy production processes and vehicle technologies, Delucchi designed various scenarios representing potential improvements in fuel production efficiencies, GWPs of GHGs, relative efficiencies of AFVs, and regional differences in fuel production.

From his study, Delucchi drew the following general conclusions:

- Coal-based fuels mostly increased GHG emissions;

- Slight to moderate reductions in GHG emissions resulted from using NG-based fuels (e.g., methanol, CNG, LNG, electricity from NG, and LPG);

- Use of woody biomass-based ethanol greatly reduced GHG emissions;

- Corn-based ethanol could increase GHG emissions;

- Use of solar energy via electricity or hydrogen nearly eliminated GHG emissions; and

- Use of nuclear energy via electricity or hydrogen greatly reduced GHG emissions.

Delucchi's is by far the most comprehensive study of energy-cycle GHG emissions. For the last several years, the study has been widely cited, and the model has been widely used. Although still credible, the emissions and energy consumption assumed by Delucchi need to be revised. At the time of the study, Delucchi used EPA's Mobile4.1 model to estimate GV emissions. Most researchers now believe that Mobile4.1 significantly underestimates actual on-road emissions. (Mobile5a - the successor of Mobile4.1 - is also believed to underestimate actual on-road emissions, but to a lesser extent.) Delucchi assumed emission reductions of AFVs relative to baseline GVs primarily on the basis of AFV emission tests conducted in the mid and late 1980s.

\subsection{NATIONAL RENEWABLE ENERGY LABORATORY ET AL. — 1991, 1992}

The National Renewable Energy Laboratory (NREL), with assistance from Oak Ridge National Laboratory and Pacific Northwest Laboratory, conducted an analysis of fuel-cycle emissions of biomass-based ethanol compared with those of reformulated gasoline (RFG) (NREL et al. 1991; 1992). The NREL study compared three fuels: RFG, E10 (mixture of 10\% ethanol and $90 \%$ gasoline by volume), and E95 (mixture of $95 \%$ ethanol and 5\% gasoline by volume). In its study, NREL assumed that E10 would be used by the year 2000, and E95 would be 
used by 2010. The researchers further assumed that ethanol in 2000 would be produced from municipal solid wastes (MSW), and in 2010 from biomass such as grasses and trees; production of ethanol from corn was excluded.

For the MSW-to-ethanol cycle in 2000, NREL selected one site: Chicago/Cook County. For the biomass-to-ethanol cycle in 2010, NREL selected five sites with distinctly different climatic, soil, and other natural parameters: Peoria, Illinois; Lincoln, Nebraska; Tifton, Georgia; Rochester, New York; and Portland, Oregon.

In estimating emissions for RFG production, NREL assumed two refineries with different levels of crude quality, refining capacity, and refinery emissions. The NREL researchers specified the compositions of RFG by using the general requirements contained in the 1990 Clean Air Act Amendments. In 1994, EPA adopted a final rule on RFG requirements that is based on potential emission reductions rather than on component compositions (U.S. EPA 1994). Because of this rule, actual RFG specifications in the future may vary among companies and will be certainly differ from NREL's assumed specifications. For example, the NREL researchers assumed that methyl tertiary butyl ether (MTBE) was the sole oxygenate for RFG. However, in practice, ethanol, ethyl tertiary butyl ether (ETBE), tertiary amyl methyl ether (TAME), ethyl tertiary amyl ether (ETAE), or MTBE can be used as an oxygenate in RFG.

The NREL study included estimates of solid waste, water pollutant, and air pollutant emissions. The air pollutants studied were VOCs, $\mathrm{CO}, \mathrm{NO}_{\mathrm{x}}, \mathrm{SO}_{\mathrm{x}}, \mathrm{CO}_{2}$, and particulate matter (PM). The researchers also calculated petroleum displacement using E10 and E95.

NREL concluded that use of MSW-based E10 in 2000 caused very little change in fuelcycle emissions compared with use of RFG because the major part of E10 was still gasoline. On the other hand, use of biomass-based $\mathrm{E} 95$ in 2010 reduced $\mathrm{CO}_{2}$ emissions by $90 \%$ to $96 \%$, and reduced $\mathrm{NO}_{x}, \mathrm{SO}_{x}$, and PM emissions considerably. However, NREL found that use of E95 could cause increases in VOC and CO emissions. On a per-mile basis, the study estimated that E10 helped displace $6 \%$ of fossil fuel use; E95 displaced $85 \%$.

NREL researchers estimated significantly larger $\mathrm{CO}_{2}$ emission reductions by using ethanol than Delucchi did, primarily because the assumptions made by NREL favored ethanol. For example, NREL assumed high energy efficiencies and low emissions of ethanol fuel cycles, a high allocation of upstream ethanol cycle emissions to other by-products, a large electricity credit earned in ethanol plants, and favorable emissions reduction for E10 and E95. NREL used EPA's Mobile4.1 to estimate emissions of RFG-fueled baseline vehicles. 


\subsection{BENTLEY ET AL. -1992}

Bentley et al. of A.D. Little prepared a study for the Idaho National Engineering Laboratory (INEL) to estimate fuel-cycle $\mathrm{CO}_{2}$ emissions from electric vehicles (EVs), fuel-cell vehicles (FCVs), and internal combustion engine vehicles (ICEVs) powered by different fuels (Bentley et al. 1992). The researchers included the following fuel cycles in their study: petroleum to gasoline, NG to methanol, NG to CNG, NG to hydrogen, corn to ethanol, and electricity generation from various fuels. While the study did not include an in-depth analysis of upstream fuelcycle emissions (energy efficiencies and $\mathrm{CO}_{2}$ emissions for upstream stages were derived primarily from other studies), it did present detailed projections of likely vehicle configurations, vehicle drivetrain, and component efficiencies.

Assuming improvements in energy efficiency for both upstream fuel production processes and vehicle technologies over time, Bentley et al. estimated $\mathrm{CO}_{2}$ emissions in three target years: 2001, 2010, and 2020. The study included three vehicle types: commuter cars, family cars, and minivans. Vehicle component energy efficiencies were projected from those of $1992 \mathrm{GVs}$. Actual on-road fuel economy of advanced vehicles was projected by using the SIMPLEV - a computer model developed at INEL to simulate vehicle fuel economy. In using SIMPLEV, Bentley et al. made assumptions regarding aerodynamics coefficients, rolling resistance, weight reduction, and battery technologies on the basis of optimistic projections of technology advances and the characteristics of some prototype vehicles. To estimate EV fuel-cycle emissions, the researchers established the following three scenarios regarding the electricity generation mix:

- The national average generation mix (under which coal-fired power plants generate over $50 \%$ of total electricity);

- Advanced NG combustion technology providing electricity for EVs; and

- The newest NG combustion technology with the highest possible conversion efficiency providing electricity for EVs.

Bentley et al. assumed that the conversion efficiency for advanced NG combustion technology would increase from $43 \%$ in 1992 to $50 \%$ in 2020 , and the efficiency for the newest NG technology would increase from $43 \%$ in 1992 to $57 \%$ in 2020.

The conclusions drawn from the Bentley et al. study included the following:

- Gasoline and methanol vehicles produce about the same amount of fuel-cycle $\mathrm{CO}_{2}$ emissions; 
- Compressed natural gas vehicles (CNGVs), EVs, and vehicles powered by ethanol (all of which produce about the same amount of $\mathrm{CO}_{2}$ emissions) generate fewer $\mathrm{CO}_{2}$ emissions than $\mathrm{GVs}$;

- EVs produce fewer emissions than CNGVs if electricity is generated from NG; and

- FCVs fueled with NG-based hydrogen generate fewer $\mathrm{CO}_{2}$ emissions than CNGVs.

\subsection{BROGAN AND VENKATESWARAN -1992}

Brogan and Venkateswaran (1992) estimated fuel-cycle energy use and $\mathrm{CO}_{2}$ emissions of various transportation technologies. Their study included EVs, hybrid electric vehicles (HEVs), FCVs, and ICEVs powered with different fuels, for a total of 19 propulsion system/fuel options. Their analysis was conducted for typical mid-size passenger cars to be introduced in 2001. So they used technology projections for 2001, except for some advanced technologies such as FCVs and HEVs, for which they used technology assumptions from prototype or concept designs.

Brogan and Venkateswaran calculated $\mathrm{CO}_{2}$ emissions by assuming that all carbon contained in a fuel was oxidized into $\mathrm{CO}_{2}$; carbon contained in $\mathrm{CO}$ and hydrocarbon (HC) emissions was not considered. Upstream emissions of $\mathrm{HC}, \mathrm{CO}, \mathrm{NO}_{\mathrm{x}}$, and $\mathrm{SO}_{\mathrm{x}}$ were estimated only for the fuel production stage (e.g., petroleum refining and electricity generation); emissions from primary energy production and distribution, transportation, and storage of fuels were ignored. It appears that the authors used emission standards of ICEVs to represent actual on-road emissions.

In estimating EV energy use, Brogan and Venkateswaran made optimistic assumptions about battery technologies. They specified a series, range-extended HEV design and assumed methanol-fueled ceramic gas turbines for the HEV design. They arbitrarily assumed that for HEVs, $75 \%$ of the road power demand would be met with grid electricity and $25 \%$ with on-board gas turbine generators. Performance characteristics remained constant among the 19 vehicle options, except for the EVs, for which the driving range was assumed to be shorter than the range for the other vehicle types. Vehicle component efficiencies were derived directly from the projections made in the Bentley et al. study.

Brogan and Venkateswaran concluded that ICEVs fueled with gasoline, methanol, CNG, and ethanol had higher primary energy consumption rates than electric propulsion technologies (i.e., EVs, HEVs, and FCVs). Ethanol vehicles were shown to have the lowest $\mathrm{CO}_{2}$ emissions. The study revealed that, with the average electric generation mix in the United States, EVs and HEVs reduced 
$\mathrm{CO}_{2}$ emissions relative to gasoline ICEVs. The results for $\mathrm{HC}, \mathrm{CO}, \mathrm{NO}_{\mathrm{x}}$, and $\mathrm{SO}_{\mathrm{x}}$ emissions were inconclusive, because the study did not estimate these emissions for the complete fuel cycle.

\subsection{ECOTRAFFIC, AB -1992}

Researchers at Ecotraffic, $A B$, in Sweden estimated fuel-cycle emissions and primary energy consumption of various transportation fuels in Sweden (Ecotraffic, AB 1992). The Swedish study included the following fuel cycles: petroleum to gasoline, petroleum to diesel, petroleum to LPG, NG to CNG, NG to methanol, biomass to methanol, biomass to ethanol, rapeseed to vegetable oil, solar energy to hydrogen via electrolysis of water, NG to hydrogen, and electricity generation from various fuels. Fuel-cycle emissions of three criteria pollutants $\left(\mathrm{HC}, \mathrm{CO}\right.$, and $\mathrm{NO}_{\mathrm{x}}$ ) and six GHGs $\left(\mathrm{CO}_{2}, \mathrm{CH}_{4}, \mathrm{~N}_{2} \mathrm{O}, \mathrm{NO}_{\mathrm{x}}, \mathrm{CO}\right.$, and $\left.\mathrm{HC}\right)$ were estimated for three vehicle types: cars, mediumduty trucks, and buses.

Ecotraffic estimated emissions of $\mathrm{HC}, \mathrm{CO}$, and $\mathrm{NO}_{\mathrm{x}}$ from both upstream fuel production processes and vehicle operations by considering emission standards applicable to stationary sources and motor vehicles in Sweden. Emissions from the vehicles powered by diesel and gasoline were taken directly from laboratory emissions testing results. EV emissions were calculated for two electric generation mix scenarios. The first was the Swedish average electric generation mix, in which $50 \%$ of electricity is from hydropower, $45 \%$ is from nuclear energy, and the remaining $5 \%$ is from fossil fuels. Compared with the U.S. average generation mix, where over $50 \%$ of electricity is generated from coal, the Swedish mix is very clean. In the second scenario, NG was the sole primary energy source for EV electricity generation.

Ecotraffic concluded that use of nonfossil fuels could result in a greater-than-50\% reduction in GHG emissions compared with use of petroleum-based fuels. Use of diesel and vegetable oils produced the highest $\mathrm{NO}_{\mathrm{x}}$ emissions. Because almost all electricity in Sweden is generated from hydropower and nuclear energy, use of EVs reduced emissions of criteria pollutants and GHGs dramatically. Because the study was conducted using only Swedish data of emissions and energy efficiencies, its conclusions may be applicable only to Sweden.

\subsection{WANG AND SANTINI -1993}

Wang and Santini (1993) estimated fuel-cycle emissions of EVs and GVs in four U.S. cities (Chicago, Denver, Los Angeles, and New York) under different driving cycles. The study included emissions of $\mathrm{HC}, \mathrm{CO}, \mathrm{NO}_{\mathrm{x}}, \mathrm{SO}_{\mathrm{x}}$, and $\mathrm{CO}_{2}$. An early version of EAGLES - a computer simulation model for vehicle fuel consumption developed at Argonne National Laboratory - was used to estimate GV fuel economy and EV electricity consumption under different driving cycles (Marr 1995). Considering city-specific electric generation mix and power plant emissions, Wang 
and Santini estimated power plant emissions attributable to EV use in each of the four cities. By using EPA's Mobile5a model, they estimated in-use emissions of U.S. Tier 1 GVs. Petroleum refinery emissions attributable to $\mathrm{GV}$ use were included in the estimates.

Wang and Santini concluded that use of EVs reduced emissions of $\mathrm{HC}$ and $\mathrm{CO}$ by more than $98 \%$ in each of the four cities and under each of the six driving cycles studied. Emission of $\mathrm{NO}_{\mathrm{x}}$ from $\mathrm{EVs}$ depended on the stringency of $\mathrm{NO}_{\mathrm{x}}$ control by power plants and on the type of power plants that provided electricity for EVs. In Chicago, Los Angeles, and New York, $\mathrm{NO}_{\mathrm{x}}$ emissions were significantly reduced by using $\mathrm{EVs}$, while in Denver, $\mathrm{NO}_{\mathrm{x}}$ emissions were reduced only moderately. $\mathrm{EV}$ use reduced $\mathrm{CO}_{2}$ emissions significantly under low-speed driving cycles, but under high-speed driving cycles, $\mathrm{CO}_{2}$ emissions from $\mathrm{EVs}$ could increase because the $\mathrm{EV}$ energy benefit (relative to GVs) was reduced. $\mathrm{SO}_{\mathrm{x}}$ emissions in Denver increased when using $\mathrm{EVs}$ because more than half of that city's electricity is generated from coal; emissions also increased in New York, where nearly half of electricity is generated from oil.

Although Wang and Santini assumed that sodium/sulfur $(\mathrm{Na} / \mathrm{S})$ batteries would be used for EVs, when estimating EV electricity consumption, they did not account for the loss of energy from the thermal management system that was necessary to maintain the high temperature for $\mathrm{Na} / \mathrm{S}$ batteries. They took into account emissions from power plants, refinery plants, and vehicle operations, but did not consider emissions from other fuel-cycle stages.

\subsection{DARROW - 1994a, 1994b}

Darrow conducted two separate studies: one for the Gas Research Institute (GRI) to analyze fuel-cycle emissions of alternative fuels (Darrow 1994a) and the other for Southern California Gas Company to compare fuel-cycle emissions from EVs and CNGVs (Darrow 1994b).

In his GRI study, Darrow included the following fuel cycles: petroleum to conventional gasoline, petroleum to RFG, petroleum to LPG, NG to CNG, NG to methanol, NG to LPG, corn to ethanol, and electricity generation from various fuels. Fuel-cycle emissions for five criteria pollutants (reactive organic gases [ROG], $\mathrm{NO}_{\mathrm{x}}, \mathrm{CO}, \mathrm{SO}_{\mathrm{x}}$, and $\left.\mathrm{PM}_{10}\right)$ and three $\mathrm{GHGs}\left(\mathrm{CO}_{2}, \mathrm{CH}_{4}\right.$, and $\mathrm{N}_{2} \mathrm{O}$ ) were included in the study.

Darrow analyzed fuel-cycle emissions for the United States and California in two target years - 1994 and 2000. For the United States, he analyzed emissions data from various areas of the country and aggregate U.S. data on emissions and energy efficiencies. For California, Darrow included emissions occurring only within the state. Over $50 \%$ of electricity in the United States is generated from coal, while natural gas, hydropower, and nuclear are the primary sources of electricity in California. Consequently, fuel-cycle emissions in California were significantly lower than those in the United States as a whole. 
As the basis for his study, Darrow used a typical minivan powered by various fuels. For vehicular emissions, Darrow assumed federal Tier 1 standards for all ICEV types except CNGVs, for which the extremely low certification emission levels of the Chrysler CNG minivan were used. This is problematic, because the safety margin between emission standards and emission certification levels can be as large as $50 \%$ - meaning that certification levels can be $50 \%$ lower than applicable standards. Furthermore, neither emission standards nor emission certification levels represent actual on-road emissions. Because of emission control deteriorations over the life of the vehicle, lifetime average emission rates are much higher than emission standards and emission certification levels. It is also questionable to compare a very clean CNG van to other vehicles, which Darrow assumed would meet Tier 1 standards. The Chrysler CNG van is designed to achieve the lowest possible emissions. The vehicle's specialized catalyst formation, high catalyst loading, and engine modification are made to reduce engine-out $\mathrm{NO}_{x}$ emissions. If the same intense emission control measures were applied to other vehicle types, their emissions would certainly be lower.

In the United States, Darrow showed that the fuel-cycle $\mathrm{NO}_{\mathrm{x}}$ emissions generated from ICEVs powered by conventional gasoline, RFG, and LPG were similar. ICEVs powered by E85 and M85 had relatively high $\mathrm{NO}_{x}$ emissions. EVs had the highest $\mathrm{NO}_{\mathrm{x}}$ emissions, and CNGVs had the lowest.

ICEVs powered by conventional gasoline, RFG, LPG, E85, and M85 had similar ROG and $\mathrm{CO}$ emissions rates. CNGVs had significantly lower emissions, and EVs had the lowest emissions. In California, EVs were shown to have lower emissions for $\mathrm{NO}_{\mathrm{x}}$ as well as for ROG and CO. CNGVs produced the lowest $\mathrm{NO}_{\mathrm{x}}$ emissions.

The extremely low emissions from CNGVs estimated by Darrow for both the United States and California were caused by his use of the extremely low certification emission levels of the Chrysler CNG minivan for CNGVs. In fact, Darrow showed that when Tier 1 standards were applied to CNGVs as well as to other vehicle types, CNGVs usually demonstrated few emission reduction benefits; the emission rates from CNGVs were about the same as those from LPGVs.

Darrow presented GHG emissions from various transportation fuels, but did not provide the details for his GHG emission calculations. He showed that EVs and vehicles powered by E85 and M85 had high $\mathrm{CO}_{2}$-equivalent emissions; gasoline and CNG ICEVs produced GHG emissions at an equal rate, and LPGVs generated the lowest GHG emissions.

In his study for Southern California Gas Company (Darrow 1994b), Darrow compared fuel-cycle emissions from CNGVs and EVs. By using the data and assumptions that he applied in his study for GRI, he concluded that in Southern California, while in-basin emissions from EVs were generally lower than those for CNGVs, all-location emissions of $\mathrm{NO}_{\mathrm{x}}$ from EVs were slightly higher than those from CNGVs. However, EVs always generated lower all-location ROG and CO emissions than CNGVs. 


\subsection{ACUREX - 1995}

Acurex Environmental Corporation conducted a study for the California Air Resources Board (CARB) to estimate the fuel-cycle emissions of RFG, clean diesel, and alternative transportation fuels (Acurex 1995). In its study, Acurex included the following fuel cycles: petroleum to conventional gasoline, petroleum to RFG, petroleum to clean diesel, NG to LPG, NG to methanol, NG to CNG, NG to LNG, coal to methanol, biomass (including corn, woody and herbaceous biomass) to methanol, biomass to ethanol, electricity generation from various fuels, and hydrogen from electricity via electrolysis of water. The study involved three criteria pollutants $\left(\mathrm{NO}_{\mathrm{x}}, \mathrm{NMOG}, \mathrm{CO}\right)$ and two GHGs $\left(\mathrm{CO}_{2}\right.$ and $\left.\mathrm{CH}_{4}\right)$. NMOG emissions from different fuel production processes and from vehicles using different alternative fuels were adjusted to account for their ozone-forming potentials.

Acurex established a framework of estimating fuel-cycle emissions in California between 1990 and 2010. Emission regulations applicable to this timeframe in California were taken into account. In particular, Acurex considered the reductions in stationary source emissions brought about by the adoption of emission regulations by the South Coast Air Quality Management District (SCAQMD). Given the uncertainties involved in emission controls and fuel economy improvements from the present to 2010, Acurex established three scenarios in 2010 to reflect varying degrees of stationary emission controls and vehicle fuel economy.

Acurex produced an $\mathrm{HC}$ speciation profile for NMOG emissions from each fuel-cycle stage and for each vehicle type to estimate ozone reactivity-adjusted NMOG emissions. The speciated NMOG emissions were then multiplied by the maximum incremental ozone reactivity factors developed by CARB to calculate ozone reactivity-adjusted NMOG emissions. Only NMOG emissions occurring within California were taken into account in fuel-cycle NMOG emission calculations.

In calculating EV emissions, Acurex used four sets of electric generation mix: a marginal generation mix for EVs in California, average generation mix in the South Coast Air Basin, U.S. average generation mix, and worldwide average generation mix. The worldwide average generation mix may have little meaning because EVs will not be introduced worldwide.

The Acurex study revealed the following information about per-mile emissions from vehicles in 2010. Vehicles powered by LNG, CNG, LPG, and hydrogen generated the lowest $\mathrm{CO}_{2}$ emissions; followed by vehicles powered by M100, M85, E85, and diesel; then by gasoline-powered vehicles. EVs had the highest $\mathrm{CO}_{2}$ emissions. In fact, $\mathrm{EV} \mathrm{CO}_{2}$ emissions were more than twice as high as those for GVs.

For $\mathrm{NO}_{\mathrm{x}}$ emissions occurring within the South Coast Air Basin, vehicles powered by $\mathrm{CNG}$, hydrogen, LPG, electricity, and diesel generated the lowest emissions; followed by vehicles 
powered by E85, M85, and RFG; then by vehicles powered by M100. Vehicles powered by LNG produced the highest in-basin $\mathrm{NO}_{\mathrm{x}}$ emissions (emissions from LNG-powered vehicles were five times as high as emissions from GVs).

Vehicles powered by hydrogen, LNG, electricity, CNG, M100, and diesel generated the lowest ozone reactivity-adjusted NMOG emissions; followed by vehicles powered by E85 and M85; then by GVs. LPG vehicles generated the highest ozone-adjusted NMOG emissions.

In its study, Acurex thoroughly characterized emissions of various fuel production processes in California, especially in the South Coast Air Basin. Acurex collected extensive emissions data, and its established fuel-cycle framework will serve as a useful tool to estimate fuel-

cycle emissions in California. However, the study did not include $\mathrm{PM}_{10}$ and $\mathrm{SO}_{\mathrm{x}}$ emissions. $\mathrm{PM}_{10}$ and other fine particulates have increasingly become a concern as studies have found that fine particulates may have already caused significant damages to human health. Researchers' ability to apply the Acurex framework for California to other regions in the United States remains unclear.

\subsection{SUMMARY}

Of the eight studies discussed in Section 2, those conducted by Delucchi and Acurex are the most comprehensive, although neither study included $\mathrm{PM}_{10}$ and $\mathrm{SO}_{\mathrm{x}}$ emissions. Through his study, Delucchi established a spreadsheet-based model to calculate GHG emissions. Acurex established a framework to calculate fuel-cycle emissions. But because the framework was designed for California only, it is not clear whether the framework can be used to estimate emissions for other U.S. regions.

Because of the different assumptions regarding upstream energy conversion efficiencies, technology pathways, emission control intensities, and vehicular emissions used in the studies, different studies of the same technology may generate significantly different emission results. The limitations of the previous studies and available models reveal a need to develop a user-friendly model so that different transportation technologies can be compared by using systematic assumptions. 


\section{MODELING APPROACH}

\subsection{FUEL CYCLES AND THEIR STAGES}

For a given transportation fuel, a fuel cycle includes the following chain of processes: energy feedstock (or primary energy) production, feedstock transportation and storage (T\&S); fuel (or energy source) production; fuel transportation, storage, and distribution (T\&S\&D); and fuel combustion. The energy cycle for a vehicle technology is supposed to include the cycle for producing the vehicle (vehicle production, operations, disposal and recycling) and the cycle for producing the fuel used in the vehicle. The current version of the GREET is a fuel-cycle model. The model may be developed as an energy-cycle model in the future. The current version includes the following 17 fuel cycles (Table 1): 11 primary energy sources (petroleum; NG; coal; uranium; corn; woody biomass; herbaceous biomass; landfill gases; and hydropower, solar energy, and wind) and nine fuels (conventional gasoline, RFG, clean diesel, LPG, CNG, methanol, ethanol, hydrogen, and electricity). Because electricity generated from hydropower, solar energy, and wind has virtually no emissions, these cycles are treated together as zero-emission cycles in the GREET. The 17 fuel cycles selected are included in the GREET essentially because of a general interest and the availability of data. Other cycles can be added to the GREET, as data on their emissions and energy use become available.

\subsection{VEHICLE TYPES}

The current version of the GREET model estimates the emissions and energy use of lightduty vehicles (i.e., passenger cars, vans, and light-duty trucks). Heavy-duty vehicles will be incorporated into a future version. For light-duty vehicles, the GREET includes the following technologies: EVs; HEVs; FCVs fueled with hydrogen or methanol; and ICEVs fueled with RFG, low-sulfur diesel (LSD), CNG, M85, M100, LPG, E85, or E100.

\subsection{CALCULATION OF ENERGY USE DURING A FUEL-CYCLE STAGE}

The GREET calculates fuel-cycle grams-per-mile (g/mi) emissions and Btu-per-mile (Btu/mi) energy use for each combination of vehicle technologies and fuels. The model also calculates changes in $\mathrm{g} / \mathrm{mi}$ emissions and Btu/mi energy use by advanced or alternative vehicle technologies relative to conventional GVs (the benchmark vehicle). The fuel-cycle energy use for a given technology is calculated by taking into account the amount of energy consumed during each of the stages involved in a fuel cycle. 
TABLE 1 Fuel Cycles Included in the GREET Model

\begin{tabular}{ll}
\hline \multicolumn{1}{c}{ Primary Energy Source } & \multicolumn{1}{c}{ Fuel } \\
\hline Petroleum & Conventional gasoline \\
& RFG \\
& Clean diesel \\
& LPG \\
& Electricity via residual oil \\
& CNG \\
Natural gas & LPG \\
& Methanol \\
& Hydrogen \\
& Electricity \\
Coal & Electricity \\
Uranium & Electricity \\
Hydropower, solar energy, wind & Electricity \\
Corn & Ethanol \\
Woody biomass & Ethanol \\
Herbaceous biomass & Ethanol \\
Landfill gases & Methanol \\
\hline
\end{tabular}

Because fuel-cycle fossil fuel and petroleum consumption are of interest, the model is designed to calculate both of these values as well as fuel-cycle total energy consumption. Fossil fuels here include petroleum, natural gas, and coal. Thus, the GREET model can estimate fossil fuel and petroleum displacement by advanced vehicle technologies or alternative fuel technologies relative to conventional GVs.

For each fuel-cycle stage, the energy efficiency - defined as the energy throughput divided by energy input (including process energy as well as feedstock energy) - is assumed first. The energy efficiencies of each of fuel-cycle stage have been estimated in previous studies. For this study, we reviewed the previous research and assumed the set of default energy efficiencies that is presented in the GREET model.

By using the assumed energy efficiency for a given stage, we calculate energy use for the stage in Btu per million Btu (Btu/10 6 Btu) of energy throughput as $10^{6} \mathrm{Btu} \times(1 /$ efficiency -1$)$. The calculated total energy consumption for the particular stage is allocated into different process fuels burned during the stage. For example, if $10^{3} \mathrm{Btu}$ is consumed for $10^{6} \mathrm{Btu}$ of fuel throughput during a given stage, the GREET model allocates the $10^{3}$ Btu into various process fuels such as diesel, residual oil, electricity, etc. The model includes the following process fuels: NG, residual oil, diesel, gasoline, crude oil, coal, electricity, and biomass. Allocation of the total energy consumption to the different process fuels is necessary to calculate the emissions for each stage because the level of emissions attributable to fuel combustion depends very much on the type of fuel burned; so 
emissions must be calculated at each stage for each fuel burned. The allocation process is also necessary for calculating fossil fuel use and petroleum use for each stage. The shares of process fuels in total energy consumption for various fuel-cycle stages are taken primarily from Delucchi (1991 and 1993).

\subsection{CALCULATION OF EMISSIONS FOR EACH FUEL-CYCLE STAGE}

Emissions of VOCs, $\mathrm{CO}, \mathrm{NO}_{\mathrm{x}}, \mathrm{PM}_{10}, \mathrm{SO}_{\mathrm{x}}, \mathrm{CH}_{4}, \mathrm{~N}_{2} \mathrm{O}$, and $\mathrm{CO}_{2}$ for a particular stage are calculated in grams per million $\mathrm{Btu}\left(\mathrm{g} / 10^{6} \mathrm{Btu}\right)$ of fuel throughput from the stage. Emissions during a stage include those from combustion of process fuels, fuel leakage and evaporation, and other emission sources. Emissions from combustion of process fuels for a particular stage are calculated by using the following formula:

$$
\text { Emissions }_{\mathrm{i}}=\Sigma_{\mathrm{j}} \Sigma_{\mathrm{k}} \mathrm{EF}_{\mathrm{i}, \mathrm{j}, \mathrm{k}} \times \mathrm{FC}_{\mathrm{j}, \mathrm{k}} \div 1,000,000
$$

where:

$$
\begin{aligned}
\text { Emissions }_{\mathrm{i}}= & \text { Emissions of pollutant } \mathrm{i} \text { in } \mathrm{g} / 10^{6} \mathrm{Btu} \text { of fuel throughput; } \\
\mathrm{EF}_{\mathrm{i}, \mathrm{j}, \mathrm{k}}= & \begin{array}{l}
\text { Emission factor of pollutant } \mathrm{i} \text { for process fuel } \mathrm{j} \text { with combustion } \\
\text { technology } \mathrm{k}\left(\mathrm{g} / 10^{6} \mathrm{Btu}\right. \text { of fuel burned); }
\end{array} \\
\mathrm{FC}_{\mathrm{j}, \mathrm{k}}= & \begin{array}{l}
\text { Consumption of process fuel } \mathrm{j} \text { with combustion technology } \mathrm{k} \\
\left(\mathrm{Btu} / 10^{6} \mathrm{Btu}\right. \text { of fuel throughput). }
\end{array}
\end{aligned}
$$

Emission factors for VOCs, $\mathrm{CO}, \mathrm{NO}_{\mathrm{x}}, \mathrm{PM}_{10}, \mathrm{CH}_{4}$, and $\mathrm{N}_{2} \mathrm{O}$ for different process fuels with different combustion technologies are derived from the fifth edition of EPA's AP-42 document (EPA 1995). The GREET model has an archive containing emission factors for 38 combustion technologies.

In the GREET model, the $\mathrm{SO}_{x}$ emission factors for the combustion technologies fueled with NG, LSD, gasoline, and LPG are calculated by assuming that all sulfur contained in these process fuels is converted into sulfer dioxide $\left(\mathrm{SO}_{2}\right)$. The following formula is used to calculate the $\mathrm{SO}_{\mathrm{x}}$ emissions of these combustion technologies:

$$
\mathrm{SO}_{x}=\text { Density } \div \text { LHV } \times 1,000,000 \times \text { S_ratio } \times 64 \div 32
$$


where:

$\mathrm{SO}_{\mathrm{x}}=\mathrm{SO}_{\mathrm{x}}$ emission factor for a particular combustion technology burning a particular fuel (in $\mathrm{g} / 10^{6} \mathrm{Btu}$ of the fuel burned);

Density = Density of the fuel (in g/gal for LSD, gasoline, and LPG, or $\mathrm{g} /$ standard curb ft for NG);

LHV = Low heating value of the fuel (in Btu/gal for LSD, gasoline, and $\mathrm{LPG}$, or Btu/standard curb $\mathrm{ft}$ for $\mathrm{NG}$ );

S_ratio = Sulfur ratio by weight for the fuel;

$64=$ Molecular weight of $\mathrm{SO}_{2}$; and

32 = Molecular weight of elemental sulfur.

$\mathrm{SO}_{\mathrm{x}}$ emission factors for combustion technologies fueled with residual oil, crude oil, and coal, where desulfurization measures are usually applied, are derived from the fifth edition of EPA's AP-42 document (EPA 1995).

In the GREET model, $\mathrm{CO}_{2}$ emissions are calculated by using a carbon balance approach, in which the carbon contained in the fuel burned minus the carbon contained in combustion emissions of VOCs, $\mathrm{CO}$, and $\mathrm{CH}_{4}$ is assumed to convert to $\mathrm{CO}_{2}$. The following formula is used to calculate $\mathrm{CO}_{2}$ emissions:

$$
\begin{aligned}
\mathrm{CO}_{2}= & {\left[\text { Density } \div \mathrm{LHV} \times 1,000,000 \times \mathrm{C}_{\text {ratio }}-(\mathrm{VOC} \times 0.85+\mathrm{CO} \times 0.43\right.} \\
& \left.\left.+\mathrm{CH}_{4} \times 0.75\right)\right] \times 44 \div 12
\end{aligned}
$$

where:

$$
\begin{aligned}
\mathrm{CO}_{2}= & \begin{array}{l}
\mathrm{CO}_{2} \text { emission factor for a particular combustion technology } \\
\text { burning a particular fuel (in } \mathrm{g} / 10^{6} \mathrm{Btu} \text { of the fuel burned); }
\end{array} \\
\text { Density = } & \begin{array}{l}
\text { Density of the fuel burned (in g/gal for liquid fuels, or } \mathrm{g} / \text { standard } \\
\text { curb } \mathrm{ft} \text { for } \mathrm{NG}) ;
\end{array} \\
\mathrm{LHV}= & \begin{array}{l}
\text { Low heating value of the fuel burned (in Btu/gal for liquid fuels, } \\
\text { or Btu/standard curb } \mathrm{ft} \text { for } \mathrm{NG} \text { ); }
\end{array}
\end{aligned}
$$




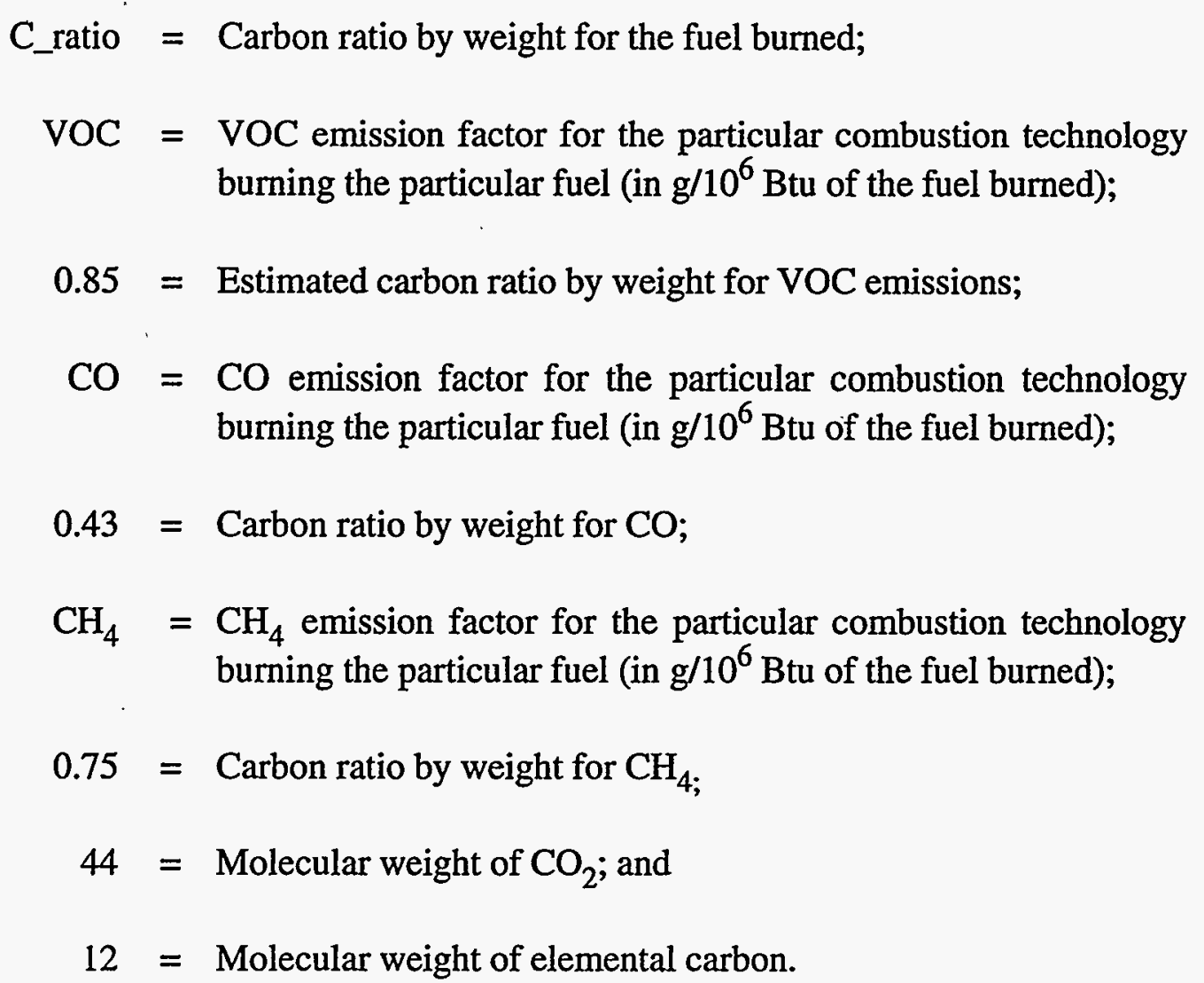

Calculations involved in formulas (1), (2), and (3) require fuel specifications such as low heating value, fuel density, weight ratio of carbon, and weight ratio of sulfur. Fuel specifications for various fuels are presented in the GREET model. Throughout the model, low heating values are used for all the fuels involved.

The GREET model takes into account the following emissions caused by mechanisms other than combustion. (Details concerning calculation of noncombustion emissions are presented in the following sections.)

- For liquid fuels, VOC evaporative emissions and emissions from fuel spillage for feedstock T\&S and fuel T\&S\&D;

- For gaseous fuels, emissions from gas leakage;

- For petroleum-based fuels, emissions from NG flaring in oil fields and noncombustion emissions in petroleum refineries;

- For NG-based fuels, $\mathrm{CH}_{4}$ emissions caused by gas leakage and noncombustion emissions during NG processing and during fuel production;

- For ethanol fuels, emissions from fertilizer production, $\mathrm{NO}_{\mathrm{x}}$ and $\mathrm{N}_{2} \mathrm{O}$ emissions from fertilizer decomposition, and noncombustion emissions during ethanol production; and 
- For the coal-to-electricity cycle, $\mathrm{CH}_{4}$ emissions during coal mining and noncombustion emissions during coal processing.

Emissions from ICEVs powered by conventional fuels (i.e., conventional gasoline, RFG, and clean diesel) are included in the GREET model for two reasons. First, heavy-duty trucks fueled with diesel or gasoline are used for fuel transportation and distribution (T\&D), so their emissions need to be taken into account in calculating emissions during this process. Second, emissions of benchmark light-duty GVs are needed for calculating vehicular emissions for both benchmark GVs and AFVs. In the GREET model, vehicular emissions from AFVs are calculated by using benchmark GV emissions and emission reductions by AFVs relative to benchmark GVs. Emissions of VOCs, $\mathrm{CO}$, and $\mathrm{NO}_{\mathrm{x}}$ for benchmark GVs, light-duty vehicles fueled by RFG and LSD, and heavy-duty trucks fueled by LSD are calculated with EPA's Mobile5a outside of the GREET model; $\mathrm{PM}_{10}$ emissions are calculated with EPA's PART5 outside of the GREET model; $\mathrm{SO}_{\mathrm{x}}$ emissions from these vehicles are calculated inside of the GREET model with the assumption that all sulfur contained in RFG or LSD is converted into $\mathrm{SO}_{2}$; emissions of $\mathrm{CH}_{4}$ and. $\mathrm{N}_{2} \mathrm{O}$ are estimated from existing data sources; and $\mathrm{CO}_{2}$ emissions from these vehicles are calculated by using a carbon balance approach (carbon contained in RFG or diesel minus carbon contained in emissions of VOCs, $\mathrm{CO}$, and $\mathrm{CH}_{4}$ is assumed to convert to $\mathrm{CO}_{2}$ ). Emissions of VOCs, $\mathrm{CO}, \mathrm{NO}_{\mathrm{x}}, \mathrm{PM}, \mathrm{CH}_{4}$, and $\mathrm{N}_{2} \mathrm{O}$ for AFVs are estimated from benchmark GV emissions and AFV emission reduction potentials. Emissions of $\mathrm{SO}_{\mathrm{x}}$ and $\mathrm{CO}_{2}$ for AFVs are calculated by using the same process used for benchmark GVs.

Besides providing separate emission estimates for each of the three $\mathrm{GHGs}\left(\mathrm{CO}_{2}, \mathrm{CH}_{4}\right.$, and $\mathrm{N}_{2} \mathrm{O}$ ), the GREET model combines these three GHGs with their GWPs to estimate $\mathrm{CO}_{2}$-equivalent GHG emissions. Based on documents prepared by the Intergovernmental Panel on Climatic Change (IPCC 1995), the GREET model uses a set of default GWPs for the three GHGs: 1 for $\mathrm{CO}_{2}, 21$ for $\mathrm{CH}_{4}$, and 310 for $\mathrm{N}_{2} \mathrm{O}$.

In estimating upstream emissions, the GREET model takes into account, in most cases, the first-order emissions only. That is, for a given stage, emissions occurring directly during the stage are considered; emissions beyond that stage - such as those occurring during production of the fuels that are, in turn, burned during the stage - are not considered. Second-order emissions are taken into account in only two cases. The first is for electricity generation, where emissions of electricity generated at power plants are considered for the stages in which electricity is used as a process fuel. The other exception is emissions of fertilizer products, which are considered for production of corn and biomass where fertilizer is applied. 
For the five criteria pollutants (VOCs, $\mathrm{CO}, \mathrm{NO}_{\mathrm{x}}, \mathrm{PM}_{10}$, and $\mathrm{SO}_{\mathrm{x}}$ ), the model calculates both all-location and in-basin emissions. In-basin emissions are important because they pose a significant human exposure risk. Users need to provide information on the share of in-basin and outof-basin facilities for each upstream fuel stage. Using the shares, the GREET calculates in-basin emissions from all-location emissions. 


\section{CALCULATION OF FUEL-CYCLE EMISSIONS AND ENERGY USE}

Default values for technology shares, emissions, and energy efficiencies are provided for each of the 17 fuel cycles in the GREET model. This section presents detailed assumptions and data sources for these default values. The default values provided in the GREET are for the year 2005. By modifying these default values, one can simulate any other target years in the GREET.

\subsection{PETROLEUM-BASED FUEL CYCLES}

The GREET model includes four petroleum-based fuel cycles: petroleum to RFG, petroleum to LSD, petroleum to electricity via residual oil, and petroleum to LPG. Detailed assumptions on energy efficiencies and emissions for these four cycles are presented in the following sections.

\subsubsection{Energy Efficiencies}

Table 2 lists data sources and assumed energy efficiency values for the petroleum-based energy stages.

\subsubsection{VOC Evaporation and Fuel Spillage}

Delucchi, Greene, and Wang (1992) estimated VOC evaporative emissions of $0.009 \mathrm{~g} / 10^{6} \mathrm{Btu}$ of crude produced during oil drilling, $0.197 \mathrm{~g} / 10^{6} \mathrm{Btu}$ produced during treatment in the oil fields, and $0.496 \mathrm{~g} / 10^{6} \mathrm{Btu}$ generated during storage in the oil fields. On the basis of their estimates, the GREET model assumes a VOC evaporative emission rate of $0.702 \mathrm{~g} / 10^{6} \mathrm{Btu}$ of crude produced for crude recovery.

Delucchi, Greene, and Wang (1992) estimated VOC evaporative emissions of $0.162 \mathrm{~g} / 10^{6} \mathrm{Btu}$ of crude handled during loading to vessels and for vessels in transit, and $1.372 \mathrm{~g} / 10^{6} \mathrm{Btu}$ of crude during storage at refineries. On the basis of these estimates, the GREET model assumes a VOC evaporative emission rate of $1.534 \mathrm{~g} / 10^{6}$ Btu for crude transportation and storage.

NREL et al. (1991) estimated VOC evaporative emissions of $7.92 \mathrm{~g} / 10^{6} \mathrm{Btu}$ of RFG and VOC spillage emissions of $3.34 \mathrm{~g} / 10^{6} \mathrm{Btu}$ during T\&S\&D of RFG. These emission rates are used in the GREET model. For diesel and LPG, no evaporative emissions are assumed. Emissions from spillage (in gal/gal of fuel handled) are assumed to be constant among RFG, diesel, and LPG. On 
data, emissions from sulfur recovery plants and water treatment plants are ignored here. On the basis of EPA's AP-42 document (EPA 1995), we estimated in this study that noncombustion emissions at refineries are $0.998 \mathrm{~g} / 10^{6} \mathrm{Btu}$ of RFG produced for VOCs, $0.358 \mathrm{~g} / 10^{6} \mathrm{Btu}$ for $\mathrm{CO}, 4.260 \mathrm{~g} / 10^{6}$ Btu for $\mathrm{NO}_{\mathrm{x}}, 1.429 \mathrm{~g} / 10^{6} \mathrm{Btu}$ for $\mathrm{PM}_{10}^{1}, 6.481 \mathrm{~g} / 10^{6} \mathrm{Btu}$ for $\mathrm{SO}_{\mathrm{x}}$, and $1,172 \mathrm{~g} / 10^{6} \mathrm{Btu}$ for $\mathrm{CO}_{2}$. For diesel, LPG, and residual oil, we assumed that noncombustion emissions are proportional to the intensity of the refining process involved in producing each fuel. Thus, the noncombustion emission rates for RFG are adjusted by the difference in energy intensity between RFG and each of these three other fuels to generate noncombustion emission rates for each.

\subsection{NATURAL-GAS-BASED FUEL CYCLES}

Five NG-based fuel cycles are included in the GREET model: NG to CNG, NG to methanol, NG to LPG, NG to hydrogen, and NG to electricity. Assumptions concerning energy efficiencies and emissions for these $\mathrm{NG}$ cycles are presented in the following sections.

\subsubsection{Energy Efficiencies}

Table 3 lists the data sources and values for energy efficiencies of NG-based fuel-cycle stages used in the GREET model.

\subsection{2 $\mathrm{CH}_{4}$ Leakage and Fuel Spillage}

Delucchi (1993) estimated that $0.2 \%$ of the gas produced in NG fields leaks into the atmosphere. Using Delucchi's estimate, we calculated that leakage in NG fields is $44.181 \mathrm{~g} / 10^{6} \mathrm{Btu}$ of $\mathrm{NG}$ produced; we also assumed that all $\mathrm{NG}$ leaked is $\mathrm{CH}_{4}$.

Delucchi (1993) estimated that $0.4 \%$ of NG leakage occurs during T\&D; this translates into a $\mathrm{CH}_{4}$ emission rate of $88.362 \mathrm{~g} / 10^{6} \mathrm{Btu}$ of $\mathrm{NG}$ transported and distributed.

Spillage of VOCs during methanol T\&S\&D is calculated by assuming that the spillage rate (in gal/gal of methanol handled) is the same as the rate for RFG. The gal/gal spillage rate is then converted into $\mathrm{g} / 10^{6} \mathrm{Btu}$ of methanol handled using the mass density and energy content values for RFG methanol. 
TABLE 2 Energy Efficiencies of Petroleum-Based Fuel-Cycle Stages

\begin{tabular}{|c|c|c|c|c|c|c|}
\hline \multirow[b]{2}{*}{$\begin{array}{l}\text { Petroleum-Based } \\
\text { Fuel-Cycle Stage }\end{array}$} & \multicolumn{6}{|c|}{ Energy Efficiency (\%) } \\
\hline & GREET & $\begin{array}{l}\text { NREL et al. } \\
\text { (1991) }\end{array}$ & $\begin{array}{l}\text { Delucchi } \\
\text { (1991) }\end{array}$ & $\begin{array}{c}\text { Ecotraffic, AB } \\
\text { (1992) }\end{array}$ & $\begin{array}{c}\text { Bentley et al. } \\
\text { (1992) }\end{array}$ & $\begin{array}{l}\text { Acurex } \\
\text { (1995) }\end{array}$ \\
\hline Crude recovery & 98.0 & 99.2 & 97.5 & 97.0 & NE & NE \\
\hline Crude T\&S & 99.5 & 96.2 & 99.8 & 99.3 & 96.0 & $\mathrm{NE}$ \\
\hline RFG refining & 82.5 & 90.0 & 81.7 & 84.5 & 90.0 & 82.8 \\
\hline RFG T\&S\&D & 98.5 & 97.7 & 99.2 & 98.6 & 98.0 & $\mathrm{NE}$ \\
\hline LPG refining & $93.5^{\mathrm{a}}$ & $\mathrm{NE}^{\mathrm{b}}$ & 94.6 & 90.0 & $\mathrm{NE}$ & 93.2 \\
\hline LPG T\&S\&D & $98.0^{c}$ & NE & 99.0 & 97.5 & NE & $\mathrm{NE}$ \\
\hline Residual refining & $95.0^{\mathrm{a}}$ & NE & 94.9 & 97.0 & NE & $\mathrm{NE}$ \\
\hline Residual T\&S\&D & $99.0^{c}$ & NE & 99.0 & $\mathrm{NE}$ & $\mathrm{NE}$ & NE \\
\hline LSD refining & $93.0^{\mathrm{a}}$ & NE & 93.0 & NE & NE & NE \\
\hline LSD T\&S\&D & $98.7^{\mathrm{c}}$ & $\mathrm{NE}$ & 99.1 & NE & NE & NE \\
\hline
\end{tabular}

a On the basis of the refining intensity involved in generating each product, the GREET model assumes that the order of refinery efficiency (from low to high) is RFG, LSD, LPG, and residual oil.

b $N E=$ not estimated.

c Primarily on the basis of the energy content per gallon of each fuel, the GREET model assumes that the order of T\&S\&D efficiency (from low to high) is LPG, RFG, LSD, and residual oil. Besides the energy content of each fuel, transportation distance and length of storage time affect the T\&S\&D efficiency of each product. While efficiencies for RFG and residual oil are simply assumed, the efficiency values for LPG and LSD are calculated by using the efficiency of RFG and the energy content of RFG, LPG, and LSD.

the basis of this assumption, the RFG spillage emission rate (in $\mathrm{g} / 10^{6} \mathrm{Btu}$ ) is adjusted to the spillage emissions rates for diesel and LPG, considering their mass density and energy content. For residual oil, the model assumes that evaporative emissions are $50 \%$ of those for RFG because of the low volatility of residual oil. Spillage emissions (in gal/gal of residual oil handled) are assumed to be $80 \%$ of those for RFG because of the short distance of transportation and infrequent loading involved in residual oil T\&S\&D.

\subsubsection{Noncombustion Emissions at Refineries}

Besides those generated during fuel combustion, emissions are produced by noncombustion sources such as catalyst regeneration, thermal cracking, and blowdown systems at refineries. Fugitive emissions are also produced in various refining processes. Because of a lack of 
TABLE 3 Energy Efficiencies of Natural-Gas-Based Fuel-Cycle Stages

\begin{tabular}{|c|c|c|c|c|c|c|c|c|c|}
\hline \multirow[b]{2}{*}{$\begin{array}{c}\text { NG-Based } \\
\text { Fuel-Cycle Stage }\end{array}$} & \multicolumn{9}{|c|}{ Energy Efficiency (\%) } \\
\hline & GREET & $\begin{array}{l}\text { Delucchi } \\
\text { (1991) }\end{array}$ & $\begin{array}{l}\text { Bentley } \\
\text { (1992) }\end{array}$ & $\begin{array}{c}\text { Ecotraffic, AB } \\
\text { (1992) }\end{array}$ & $\begin{array}{l}\text { NREL } \\
\text { (1992) }\end{array}$ & $\begin{array}{l}\text { Smith } \\
\text { (1993) }\end{array}$ & $\begin{array}{l}\text { Acurex } \\
(1995)\end{array}$ & $\begin{array}{l}\text { Darrow } \\
\text { (1994a) }\end{array}$ & $\begin{array}{l}\text { Darrow } \\
\text { (1994b) }\end{array}$ \\
\hline NG recovery & 97.0 & 97.2 & 94.0 & 97.0 & $\mathrm{NE}^{\mathrm{a}}$ & NE & 96.2 & $\mathrm{NE}$ & $\mathrm{NE}$ \\
\hline NG processing & 97.5 & 97.5 & 97.0 & 98.0 & NE & NE & 96.2 & NE & $\mathrm{NE}$ \\
\hline NG T\&D & 97.0 & 96.4 & 97.0 & 98.0 & $\mathrm{NE}$ & NE & $\mathrm{NE}$ & NE & $\mathrm{NE}$ \\
\hline NG compression & 95.0 & 95.0 & 87.0 & 93.0 & $\mathrm{NE}$ & NE & $\mathrm{NE}$ & 97.9 & 98.0 \\
\hline Methanol production & 65.0 & 45.9 & 70.0 & 60.0 & NE & NE & 68.3 & 66.4 & $\mathrm{NE}$ \\
\hline Methanol T\&S\&D & 97.0 & 96.2 & 90.2 & 97.8 & $\mathrm{NE}$ & $\mathrm{NE}$ & $\mathrm{NE}$ & 97.7 & NE \\
\hline LPG production ${ }^{\mathrm{b}}$ & 96.5 & 96.7 & $\mathrm{NE}$ & $\mathrm{NE}$ & $\mathrm{NE}$ & $\mathrm{NE}$ & NE & $\mathrm{NE}$ & NE \\
\hline Hydrogen production & 68.0 & $\mathrm{NE}$ & NE & NE & 68.0 & 68.0 & 61.1 & $\mathrm{NE}$ & NE \\
\hline Hydrogen liquefaction & 70.0 & $70-74$ & $\mathrm{NE}$ & $\mathrm{NE}$ & $\mathrm{NE}$ & 68.0 & $\mathrm{NE}$ & NE & NE \\
\hline Hydrogen T\&S\&D & $95.0^{\mathrm{c}}$ & $\mathrm{NE}$ & NE & $\mathrm{NE}$ & $\mathrm{NE}$ & $\mathrm{NE}$ & NE & $\mathrm{NE}$ & NE \\
\hline
\end{tabular}

a $\mathrm{NE}=$ not estimated.

$b$ The energy efficiency for the T\&S\&D of LPG is presented in Table 2.

c An efficiency for T\&S\&D of liquid hydrogen lower than the efficiencies for T\&S\&D of other liquid fuels is assumed here primarily because the energy content of liquid hydrogen is lower than those for other liquid fuels. 


\subsubsection{Noncombustion Emissions during Natural Gas Processing and Fuel Production}

$\mathrm{SO}_{\mathrm{x}}$ emissions are generated during the sweetening of $\mathrm{NG}$ (removal of $\mathrm{H}_{2} \mathrm{~S}$ contained in NG). Using a formula contained in EPA's AP-42 document (EPA 1995), and assuming an $\mathrm{H}_{2} \mathrm{~S}$ mole content for NG of $0.3 \%$ and $99 \% \mathrm{SO}_{\mathrm{x}}$ control efficiency in NG processing plants, we calculated that the $\mathrm{SO}_{\mathrm{x}}$ emission rate from NG sweetening is $2.226 \mathrm{~g} / 10^{6} \mathrm{Btu}$ of NG processed.

Because the carbon ratio of methanol is higher than that of $\mathrm{NG}$ (primarily $\mathrm{CH}_{4}$ ), the process of converting $10^{6} \mathrm{Btu}$ of $\mathrm{NG}$ to $10^{6} \mathrm{Btu}$ of methanol results in a net carbon absorption. We assumed here that the additional carbon in the $10^{6}$ Btu of methanol comes from NG burned during the conversion process. The carbon absorption rate of the methanol conversion process is estimated here as $12,495 \mathrm{~g} / 10^{6} \mathrm{Btu}$ methanol produced. This $\mathrm{CO}_{2}$ emissions value is subtracted from the $\mathrm{CO}_{2}$ emissions value calculated for NG combustion in methanol plants.

Emissions of $\mathrm{SO}_{\mathrm{x}}$ are generated during LPG production because NG contains about $0.0007 \%$ sulfur but LPG contains no sulfur. The model assumes that all sulfur contained in NG is converted into $\mathrm{SO}_{2}$ (which accounts for most $\mathrm{SO}_{\mathrm{x}}$ emissions) and that $\mathrm{SO}_{\mathrm{x}}$ emissions produced this way make up $0.155 \mathrm{~g} / 10^{6} \mathrm{Btu}$ of $\mathrm{LPG}$ produced. $\mathrm{SO}_{\mathrm{x}}$ emissions are also generated during hydrogen production; the GREET model assumes an $\mathrm{SO}_{\mathrm{x}}$ emission rate of $0.155 \mathrm{~g} / 10^{6} \mathrm{Btu}$ of hydrogen produced.

Because of the elimination of carbon in hydrogen, the conversion of NG to hydrogen produces excess $\mathrm{CO}_{2}$ emissions. We estimated that the conversion process produces $\mathrm{CO}_{2}$ at $59,777 \mathrm{~g} / 10^{6} \mathrm{Btu}$ of hydrogen produced. This $\mathrm{CO}_{2}$ emissions value is added to the $\mathrm{CO}_{2}$ emissions value for fuel combustion in hydrogen production plants.

\subsection{ETHANOL PRODUCTION CYCLES}

The GREET model includes three ethanol-producing fuel cycles: corn to ethanol, woody biomass to ethanol, and herbaceous biomass to ethanol. While the technology involved in converting corn to ethanol is mature, the technology for converting biomass (both woody and herbaceous) to ethanol has not been demonstrated commercially. The large-scale production of biomass to obtain ethanol also has yet to be demonstrated. So, while the corn-to-ethanol cycle can be treated as a nearterm option, the other cycles (herbaceous and woody biomass to ethanol) should be treated as longterm options.

In the GREET model, the emissions and energy use involved in the production of corn, woody biomass, and herbaceous biomass are calculated on the basis of the amount of fuel and fertilizer used, rather than the energy efficiencies of the production process. So, by inputting the 
amount of fuel used, the amount of fertilizer used, and the amount of energy used to produce fertilizer, we can calculate the energy efficiencies for the production of corn, woody biomass, and herbaceous biomass. However, direct use of the former values (amount of fuel and fertilizer used) in the GREET model makes the assumptions more explicit and easier to interpret.

\subsubsection{Fuel and Fertilizer Use for Corn and Biomass Production}

Table 4 presents the fuel and fertilizer usage values assumed in the GREET model for production and transportation of corn and biomass. To calculate emissions generated during manufacturing at fertilizer plants, the energy consumption for fertilizer production is needed. On the basis of information in Delucchi (1993) and Marland and Turhollow (1991), the GREET model assumes values of 62,9 , and $8 \mathrm{Btu} / \mathrm{g}$ of fertilizer nitrogen, phosphate $\left(\mathrm{P}_{2} \mathrm{O}_{5}\right)$, and potash $\left(\mathrm{K}_{2} \mathrm{O}\right)$, respectively. The breakdowns of the energy consumption into different energy sources were obtained from Delucchi (1991).

Calculated emissions and energy consumption per bushel of corn and per dry ton of biomass are converted into emissions and energy consumption $/ 10^{6} \mathrm{Btu}$ of energy produced. For this conversion, we assumed 2.6 gal of ethanol per bushel of corn (on the basis of information in Delucchi [1993] and Marland and Turhollow [1991]). The conversion for biomass is completed by using the energy content of woody and herbaceous biomass.

TABLE 4 Fuel and Fertilizer Usage for Production and Transportation of Corn and Biomass

\begin{tabular}{lrrr}
\hline $\begin{array}{c}\text { Usage Values for Corn and } \\
\text { Biomass Production }\end{array}$ & $\begin{array}{c}\text { Corn } \\
\text { (per bushel) }\end{array}$ & $\begin{array}{c}\text { Woody Biomass } \\
\text { (per dry ton) }\end{array}$ & $\begin{array}{c}\text { Herbaceous Biomass } \\
\text { (per dry ton) }\end{array}$ \\
\hline & $24,000^{\mathrm{a}}$ & $43,706^{\mathrm{b}}$ & $45,056^{\mathrm{b}}$ \\
$\begin{array}{l}\text { Fuel used for production (Btu) } \\
\text { Fertilizer use (g): }\end{array}$ & $567.5^{\mathrm{a}}$ & $1,276.8^{\mathrm{b}}$ & $4,596.8^{\mathrm{b}}$ \\
Nitrogen & $261.1^{\mathrm{a}}$ & $754.8^{\mathrm{b}}$ & $3,405^{\mathrm{b}}$ \\
$\mathrm{P}_{2} \mathrm{O}_{5}$ & $306.5^{\mathrm{a}}$ & $754.8^{\mathrm{b}}$ & $3,405^{\mathrm{b}}$ \\
$\mathrm{K}_{2} \mathrm{O}$ & $5,600^{\mathrm{a}}$ & $41,500^{\mathrm{a}}$ & $41,500^{\mathrm{a}}$ \\
Fuel used for transportation (Btu) & & & \\
\hline & & & \\
a From Delucchi (1993). & & \\
b From NREL et al. (1991). In calculating these numbers, we assumed a biomass production \\
rate of 8 dry ton/acre; this value was based on NREL et al. (1991) and McLaughlin (1993).
\end{tabular}




\subsubsection{Energy Efficiencies for Other Stages}

Emissions and energy consumption of other ethanol-cycle stages are calculated on the basis of energy balance. Table 5 presents the data sources and energy efficiency values of other stages used in the GREET model.

\subsubsection{Noncombustion Emission Sources}

$\mathrm{NO}_{\mathrm{x}}$ and $\mathrm{N}_{2} \mathrm{O}$ Emissions from Fertilizer Decomposition. Decomposition of nitrogen fertilizer produces emissions of $\mathrm{NO}_{x}$ (primarily $\mathrm{NO}$ ) and $\mathrm{N}_{2} \mathrm{O}$. On the basis of data presented in Delucchi (1993) and Williams et al. (1992), we calculated emissions values of $33.193 \mathrm{~g} \mathrm{~N}_{2} \mathrm{O}$ and

TABLE 5 Energy Efficiencies of Ethanol Production Stages (\%)

\begin{tabular}{|c|c|c|c|c|}
\hline \multirow[b]{2}{*}{$\begin{array}{l}\text { Data } \\
\text { Source }\end{array}$} & \multicolumn{4}{|c|}{ Production Stage } \\
\hline & $\begin{array}{l}\text { Corn to } \\
\text { Ethanol }\end{array}$ & $\begin{array}{l}\text { Woody } \\
\text { Biomass } \\
\text { to Ethanol }\end{array}$ & $\begin{array}{l}\text { Herbaceous } \\
\text { Biomass to } \\
\text { Ethanol }\end{array}$ & $\begin{array}{l}\text { Ethanol } \\
\text { T\&S\&D }\end{array}$ \\
\hline GREET & $50.0^{a}$ & $55.0^{\mathrm{b}}$ & $65.6^{\mathrm{b}}$ & 97.8 \\
\hline Delucchi (1991) & 42.0 & 65.0 & $\mathrm{NE}^{\mathrm{c}}$ & 97.7 \\
\hline NREL (1992) & $\mathrm{NE}$ & $\mathrm{NE}$ & $\mathrm{NE}$ & 98.2 \\
\hline Ecotraffic (1992) & NE & 53.2 & $\mathrm{NE}$ & 99.0 \\
\hline Bentley (1992) & 47.0 & $\mathrm{NE}$ & NE & 93.1 \\
\hline Darrow (1994a) & 63.6 & $\mathrm{NE}$ & $\mathrm{NE}$ & 98.4 \\
\hline Acurex (1995) & 42.3 & 49.3 & $\mathrm{NE}$ & $\mathrm{NE}$ \\
\hline Lynd (1996) & $\mathrm{NE}$ & $46.0-61.4$ & $\mathrm{NE}$ & NE \\
\hline
\end{tabular}

a The conversion efficiency for corn to ethanol does not take into account the energy contained in by-products from ethanol plants. The issue of by-products is addressed by dividing the emissions and energy use involved in ethanol production and upstream processes between ethanol and by-products. (See Section 4.3 .4 for a detailed discussion.)

b The conversion efficiency for woody and herbaceous biomass to ethanol does not take into account the energy contained in the electricity co-generated in biomass ethanol plants, which is addressed separately.

c $\mathrm{NE}=$ Not estimated. 
$13.747 \mathrm{~g} \mathrm{NO}_{\mathrm{x}}$ per bushel of corn produced, $74.684 \mathrm{~g} \mathrm{~N}_{2} \mathrm{O}$ and $30.931 \mathrm{~g} \mathrm{NO}_{\mathrm{x}}$ per dry ton of woody biomass produced, and $268.861 \mathrm{~g} \mathrm{~N}_{2} \mathrm{O}$ and $222.703 \mathrm{~g} \mathrm{NO}_{\mathrm{x}}$ per dry ton of herbaceous biomass produced.

Noncombustion Emissions during Ethanol Production. In the United States, more ethanol is currently produced from corn in wet milling facilities than in dry milling facilities. Handling and pretreatment of corn and biomass at ethanol plants produce noncombustion $\mathrm{PM}_{10}$ emissions. Noncombustion VOC emissions result from fermentation of corn and biomass, treatment of wastes and by-products, and storage of ethanol at ethanol plants. On the basis of emission factors for wet milling ethanol plants presented in EPA's AP-42 document (EPA 1995), a noncombustion $\mathrm{PM}_{10}$ emission factor of $56.158 \mathrm{~g} / 10^{6} \mathrm{Btu}$ of ethanol is estimated for corn-to-ethanol plants. A noncombustion $\mathrm{PM}_{10}$ emission rate of $5.757 \mathrm{~g}$ and a VOC emission rate of $1.873 \mathrm{~g} / 10^{6} \mathrm{Btu}$ of ethanol was estimated for woody biomass-to-ethanol plants. $\mathrm{A} \mathrm{PM}_{10}$ emission rate of $5.486 \mathrm{~g}$ and a VOC emission rate of $1.748 \mathrm{~g} / 10^{6} \mathrm{Btu}$ of ethanol was estimated for herbaceous biomass-to-ethanol plants. These estimates were based on data presented in NREL et al. (1991). A noncombustion VOC emission rate of $1.8 \mathrm{~g} / 10^{6} \mathrm{Btu}$ of ethanol is assumed for corn-to-ethanol plants.

\subsubsection{Other Critical Assumptions}

Shares of Products in Corn-to-Ethanol Plants. Corn-to-ethanol plants produce by-products that can be used for animal food or other purposes. So total emissions from ethanol plants and from upstream corn production need to be divided between ethanol and other byproducts. On the basis of data presented in Delucchi (1993), the energy share of ethanol accounts for about 55\% of the total energy contained in all products from corn-based ethanol plants. So 55\% of emissions and energy used in ethanol plants and in upstream corn production processes are allocated to ethanol; the remaining $45 \%$ are allocated to other by-products. Alternatively, the market share values of different products could be used to allocate emissions and energy use among products from corn-to-ethanol plants.

For biomass-based ethanol plants, no by-products are assumed - except that combustion of biomass through co-generation facilities in ethanol plants generates electricity and provides the heat required for ethanol production. Data in NREL et al. (1991) imply that the electricity credit was $0.062 \mathrm{Btu}$ of electricity per Btu of ethanol produced for woody biomass-to-ethanol plants and $0.038 \mathrm{Btu}$ for herbaceous biomass-to-ethanol plants. Lynd et al. (1996) estimated an electricity credit of 0.101-0.142 Btu per Btu of ethanol produced in biomass-to-ethanol plants, depending on the progress of biomass-to-ethanol conversion technologies. In the GREET model, the electricity credit is assumed to be $0.1 \mathrm{Btu}$ for woody biomass-to-ethanol plants and $0.06 \mathrm{Btu}$ for herbaceous biomass-to-ethanol plants. These are equivalent to 2.22 and 1.34 kilowatt-hours $(\mathrm{kWh}) / \mathrm{gal}$ of 
ethanol produced. The electricity generated can be exported to the electric grid. Emissions credits for the generated electricity are addressed in the GREET model by taking into account the amount of electricity generated and the average emissions associated with electricity generation.

$\mathrm{CO}_{2}$ Emissions of Biomass Combustion. In this study, we assume that biomass will be burned in biomass-to-ethanol plants to provide heat needed for ethanol production. While combustion of biomass undoubtedly produces $\mathrm{CO}_{2}$ emissions, these emissions come from the atmosphere through the photosynthesis process for biomass growth. Thus, the $\mathrm{CO}_{2}$ emissions from biomass combustion are treated as zero in the GREET model. For the same reason, the $\mathrm{CO}_{2}$ emissions from ethanol combustion in ethanol vehicles are treated as zero.

\subsection{COAL TO ELECTRICITY}

This section presents data for coal mining and coal transportation to power plants. Coal combustion in power plants and electricity transmission and distribution are discussed in Section 4.7.

\subsubsection{Energy Efficiencies}

On the basis of data presented in Delucchi (1991), Wang and Delucchi (1992), and Darrow (1994a), an energy efficiency of $99.3 \%$ is assumed in the GREET model for coal mining; an efficiency of $99.4 \%$ is assumed for coal transportation.

\subsubsection{Noncombustion Emissions}

During the coal mining process, a large amount of $\mathrm{CH}_{4}$ emissions that are contained with the coal in coal beds is released. Data presented in Delucchi (1993) were used in this study to calculate a $\mathrm{CH}_{4}$ release rate of $381.271 \mathrm{~g} / 10^{6} \mathrm{Btu}$ of coal mined.

Coal is usually cleaned at mining sites to remove impurities such as sulfur, ash, and rock. By using information contained in the AP-42 document (EPA 1995), we calculated the following emission rates for coal cleaning: $2.169 \mathrm{~g} / 10^{6} \mathrm{Btu}$ of coal processed for VOCs, $3.037 \mathrm{~g} / 10^{6} \mathrm{Btu}$ for $\mathrm{NO}_{\mathrm{x}}, 1.952 \mathrm{~g} / 10^{6} \mathrm{Btu}$ for $\mathrm{PM}_{10}$, and $5.423 \mathrm{~g} / 10^{6} \mathrm{Btu}$ for $\mathrm{SO}_{\mathrm{x}}$. 


\subsection{URANIUM TO ELECTRICITY}

Three stages of the uranium-to-electricity cycle (uranium mining, transportation, and enrichment) cause emissions because fuel combustion is involved in these stages. On the basis of data presented in Delucchi (1991), this study assumes an energy efficiency of $99.5 \%$ for uranium mining, $99.9 \%$ for uranium transportation, and $95.8 \%$ for uranium enrichment. No noncombustion emissions are assumed for this cycle.

\subsection{LANDFILL GASES TO METHANOL}

EPA (1991) estimates that 3,000 to 6,000 landfills currently produce landfill gases. Flares at the landfill sites are used to burn the released methane. Recently, TeraMeth Industries, based in California, developed a compact, mobile facility to produce methanol from landfill gases. TeraMeth is in the final stage of obtaining a permit to build a methanol production plant in southern California. The proposed facility will have a production capacity of $17,000 \mathrm{gal} /$ day of methanol. Nationwide, there are about 600 landfills that generate large quantities of gases for methanol production; the GREET model includes this cycle of producing methanol from landfill gases.

\subsubsection{Energy Efficiencies}

During the process of converting landfill gas to methanol, energy is consumed to provide steam for the conversion process, to drive equipment, and to meet power needs in the plants. On the basis of data presented by SCAQMD for the proposed TeraMeth facility in southern California (SCAQMD 1994), we estimate an energy efficiency of $89.7 \%$ for the conversion process. The GREET model assumes that $99.3 \%$ of the consumed energy is electricity and the remaining $0.7 \%$ is landfill gases. So, $804 \mathrm{Btu}$ of landfill gases and $33.4 \mathrm{kWh}$ of electricity are consumed for each $10^{6} \mathrm{Btu}$ of methanol produced. Emissions of the landfill gases burned are calculated from the amount of gases burned and the emission factors of natural gas combustion. Emissions from electricity consumption are estimated from the amount of electricity consumed and the average emission factors of electricity generation in a given region.

\subsubsection{Emission Credits of Methanol Production}

Because the production of methanol from landfill gases eliminates the practice of burning landfill gases in flares, the process of converting landfill gases to methanol earns emission credits equal to the amount of emissions otherwise produced from combustion of landfill gases. Using data presented by the SCAQMD (1994), we calculated an emissions credit of $5.582 \mathrm{~g} / 10^{6} \mathrm{Btu}$ of methanol produced for VOCs, $106.1 \mathrm{~g} / 10^{6} \mathrm{Btu}$ for $\mathrm{CO}, 21.6 \mathrm{~g} / 10^{6} \mathrm{Btu}$ for $\mathrm{NO}_{\mathrm{x}}, 35.36 \mathrm{~g} / 10^{6} \mathrm{Btu}$ for 
$\mathrm{PM}_{10}, 7.393 \mathrm{~g} / 10^{6} \mathrm{Btu}$ for $\mathrm{SO}_{\mathrm{x}}, 706.8 \mathrm{~g} / 10^{6} \mathrm{Btu}$ for $\mathrm{CH}_{4}$, and $178,715 \mathrm{~g} / 10^{6} \mathrm{Btu}$ for $\mathrm{CO}_{2}$. These emission credits, subtracted from emissions of the landfill gas-to-methanol cycle, result in negative upstream emissions. On the other hand, as discussed later, emissions of on-vehicle methanol combustion are considered in calculating emissions from ICEVs fueled with the methanol that is produced from landfill gases.

\subsection{ELECTRICITY GENERATION}

Of the various power plants, those fueled by residual oil, NG, and coal produce emissions at the plant sites. Nuclear power plants do not produce air emissions at plant sites, but emissions are associated with upstream uranium production and preparation stages. The GREET model calculates emissions associated with electricity generation from residual oil, NG, coal, and uranium. Electricity generated from hydropower, solar energy, wind, and geothermal energy is treated as having zero emissions; these sources are categorized together in one group.

\subsubsection{Combustion Technologies}

For each fuel type, various combustion technologies can be used to generate electricity. In the GREET model, both uncontrolled and controlled steam boilers are assumed for oil-fired plants. We also assumed uncontrolled steam boilers will be phased out over time. For NG-fired power plants, the model assumes steam boilers, conventional gas turbines, and advanced combined-cycle gas turbines. For coal-fired power plants, current steam boilers, future steam boilers, and integrated gasification combined-cycle technologies are assumed. Boiling water reactors are assumed for nuclear power plants. For each fuel type, users can change the combustion technology mix in the GREET model to simulate emission impacts of a given combustion technology with a given fuel.

\subsubsection{Power Plant Conversion Efficiencies}

Table 6 presents power-plant conversion efficiencies used in the GREET model and in some other studies. Among the technologies presented, oil-, NG-, and coal-fired boilers; NG-fired turbines; and nuclear plants are current technologies. Advanced NG combined-cycle turbines and integrated gasification combined-cycle processes are future technologies. Both current and future technologies are included in the GREET so that the model can simulate the impacts of using EVs and HEVs in the future, when both current and future technologies are used to generate electricity. 
TABLE 6 Energy Conversion Efficiencies of Electric Power Plants (\%)

\begin{tabular}{|c|c|c|c|c|c|c|c|c|c|}
\hline \multirow{2}{*}{$\begin{array}{c}\text { Electric Power } \\
\text { Plant Type }\end{array}$} & \multirow[b]{2}{*}{ GREET } & \multirow{2}{*}{$\begin{array}{c}\text { Delucchi } \\
\text { (1991) }\end{array}$} & \multicolumn{2}{|c|}{$\begin{array}{l}\text { Bentley } \\
\text { (1992) }\end{array}$} & \multicolumn{2}{|c|}{$\begin{array}{l}\text { Wang et al. } \\
\text { (1992) }\end{array}$} & \multirow{2}{*}{$\begin{array}{c}\text { Ecotraffic, AB } \\
(1992)\end{array}$} & \multirow{2}{*}{$\begin{array}{l}\text { Darrow } \\
(1994 a) \\
\end{array}$} & \multirow{2}{*}{$\begin{array}{c}\text { EIA } \\
(1995)\end{array}$} \\
\hline & & & 2010 & 2020 & 1990 & 2010 & & & \\
\hline Oil-fired boilers & $34-35$ & 31.8 & 34 & 34 & 31 & 35.4 & 38 & 33 & 36 \\
\hline NG-fired boilers & 34 & 32.8 & 34 & 34 & 31.3 & 39 & 38 & 33 & 36 \\
\hline NG-fired turbines & 34 & 33 & 34 & 36 & 31.4 & 31.4 & 38 & 33 & $29.8-37.3$ \\
\hline Advanced NG-fired turbines & 50 & $\mathrm{NE}^{\mathrm{a}}$ & 51 & 53 & 40 & 47 & 50 & $\mathrm{NE}$ & 46.3 \\
\hline Coal-fired boilers & $34-35$ & 32.9 & 38 & 40 & 33 & 37 & 38 & 33 & 35.4 \\
\hline Coal gasification & 40 & $\mathrm{NE}$ & $\mathrm{NE}$ & $\mathrm{NE}$ & 37.9 & 44.8 & NE & NE & 38.7 \\
\hline Nuclear plants & 34 & NE & NE & 34 & $\mathrm{NE}$ & NE & $\mathrm{NE}$ & NE & $\mathrm{NE}$ \\
\hline
\end{tabular}

a $\mathrm{NE}=$ not estimated. 


\subsubsection{Electric Generation Mixes}

The electric generation mix greatly affects the fuel-cycle emissions of EVs and HEVs. Because this mix differs significantly across the United States, use of EVs and HEVs can have very different emission impacts in different regions. Table 7 presents the electric generation mix in various U.S. regions (Figure 1 shows these regions). The data show that on the west coast and in the northeastern United States, where EV use is adopted or proposed, electricity is primarily generated from clean sources such as nuclear power, hydropower, and NG. Each of these electric generation mix sets can be input into the GREET model to simulate EV or HEV emission impacts.

\subsection{VEHICLE OPERATIONS}

The current version of the GREET model is designed to estimate fuel-cycle energy use and emissions for light-duty vehicles only. Efforts are currently being undertaken to incorporate heavy-duty vehicles. The model includes 12 vehicle types fueled with different fuels: RFG vehicles, LSD vehicles, CNG vehicles, M85 vehicles, M100 vehicles, LPG vehicles, E85 vehicles, E100 vehicles, EVs, HEVs, hydrogen fuel-cell vehicles, and methanol fuel-cell vehicles. RFG-fueled vehicles are treated as the baseline.

In estimating fuel-cycle energy use and emissions for HEVs, the GREET model assumes a generic HEV type. Although various units powered by different fuels are proposed for use in HEVs, the model includes the HEV type equipped with a gasoline engine. Energy to drive HEVs is provided from grid electricity and from on-board power generation units. Overall energy use and emissions for HEVs are calculated by using the average energy use and emissions of the grid electricity mode and the gasoline engine mode of HEVs weighted by miles traveled in each mode.

The GREET model assumes proton-exchange membrane fuel-cells for both hydrogen- and methanol-fueled FCVs. For methanol-fueled FCVs, the model assumes that methanol is reformed into hydrogen through an on-board reformer.

\subsubsection{Vehicle Fuel Economy and Component Efficiencies}

A fuel economy of 30 MPG is assumed in the GREET model for the baseline GV. Users can change baseline GV fuel economy on the basis of their own assumptions. Fuel economy for each of the other 11 vehicle types is calculated from baseline GV fuel economy and relative improvement in fuel economy between GVs and the other types. Table 8 presents default values for relative fuel economy improvements in the 11 vehicle types. Improvements in MPG values for diesel, CNG, M85, M100, LPG, E85, E100, and EVs are based primarily on Wang et al. (1993) and 
TABLE 7 Electric Generation Mix of Various U.S. Regions in $2005(\%)^{a}$

\begin{tabular}{lrrrrr}
\hline & \multicolumn{5}{c}{ Energy Source } \\
\cline { 2 - 6 } \multicolumn{1}{c}{ Region } & Coal & \multicolumn{1}{c}{ Oil } & \multicolumn{1}{c}{ NG } & Nuclear & Others \\
\cline { 2 - 6 } & & & & & \\
East Central (ECAR) & 83.6 & 0.5 & 5.1 & 8.3 & 2.4 \\
Texas (ERCOT) & 38.2 & 2.5 & 47.9 & 9.3 & 2.0 \\
Mid-Atlantic (MAAC) & 44.8 & 4.3 & 15.8 & 30.7 & 4.4 \\
Illinois and Wisconsin (MAIN) & 58.7 & 0.5 & 1.6 & 37.3 & 1.9 \\
Mid-Continent (MAPP) & 72.2 & 0.1 & 0.6 & 17.6 & 9.5 \\
New York State (NY) & 14.4 & 22.0 & 18.5 & 18.7 & 26.4 \\
New England w/o New York (NE) & 14.3 & 25.5 & 13.6 & 31.3 & 15.5 \\
Florida (FL) & 34.0 & 22.4 & 24.0 & 14.3 & 5.3 \\
Southeast w/o Florida (STV) & 57.2 & 1.4 & 5.6 & 27.8 & 8.0 \\
Southwest (SPP) & 55.3 & 1.4 & 27.8 & 10.7 & 4.8 \\
Northwest (NWP) & 27.2 & 0.1 & 15.2 & 1.8 & 55.6 \\
Rocky Mountains and Arizona (RA) & 57.8 & 0.4 & 24.6 & 6.7 & 10.5 \\
California and Southeast Nevada (CNV) & 19.6 & 3.1 & 31.8 & 19.9 & 25.6 \\
Northeastern United States Average ${ }^{b}$ & 29.4 & 14.1 & 16.0 & 27.7 & 12.9 \\
U.S. Average & 50.9 & 3.4 & 14.9 & 18.9 & 11.9 \\
\hline & & & & &
\end{tabular}

a Calculated from data presented in EIA 1995.

b The electric generation mix for the northeastern United States is the generatedelectricity weighted average of mid-Atlantic states (MAAC), New York State (NY), and the New England area without New York (NE).

Acurex (1995). As the table shows, no MPG improvements in fuel efficiency are assumed for CNG and LPG vehicles. These vehicles will be heavier than baseline GVs because of the heavy on-board storage cylinders or tanks required to fuel them; the additional vehicle weight may offset efficiency gains from fuel combustion. The improvement in fuel economy for HEVs powered with grid electricity is assumed to be the same as that for EVs. The increased MPG for HEVs in the gasoline : engine mode is based on the estimated fuel economy of various HEV designs presented in Sperling. and Burke (1994). Fuel economy increases for hydrogen FCVs are from Acurex (1995); for methanol FCVs, the increase is calculated from the improvement of hydrogen FCVs and the efficiency of on-board methanol reformers. On the basis of simulation results presented by General Motors Corporation (1994), an energy efficiency of $77 \%$ is assumed in the GREET model for methanol reformers. 


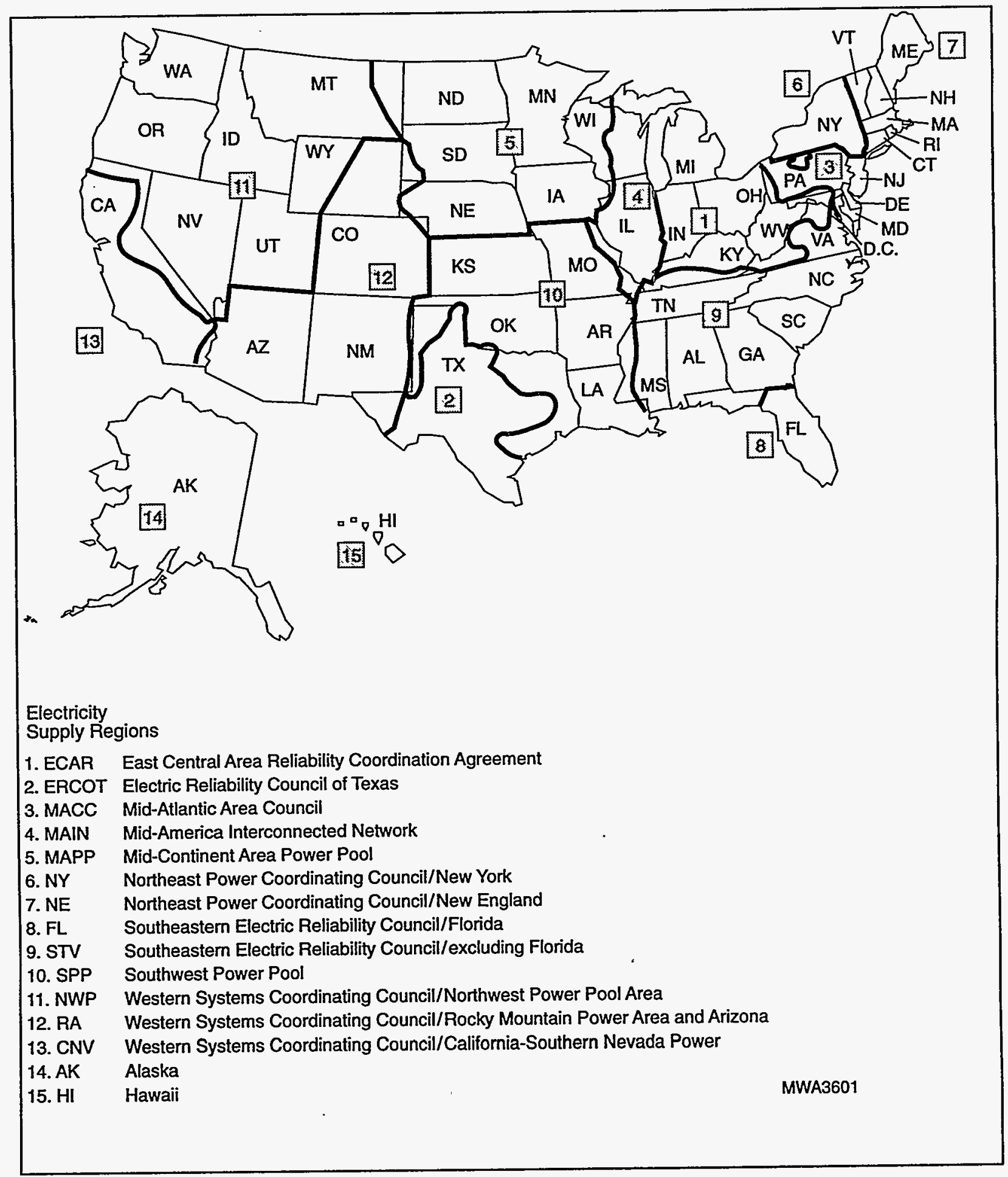

FIGURE 1 Electricity Supply Regions (from EIA 1995) 


\subsubsection{Emissions}

Emissions from vehicle operations are calculated for nine pollutants or sources: exhaust and evaporative VOCs, $\mathrm{CO}, \mathrm{NO}_{\mathrm{x}}$, exhaust $\mathrm{PM}_{10}$, brakewear and tirewear $\mathrm{PM}_{10}, \mathrm{SO}_{\mathrm{x}}, \mathrm{CH}_{4}, \mathrm{~N}_{2} \mathrm{O}$, and $\mathrm{CO}_{2}$. VOC emissions (both exhaust and evaporative), $\mathrm{CO}$, and $\mathrm{NO}_{\mathrm{x}}$ for $\mathrm{GVs}$ and diesel vehicles are calculated by using EPA's Mobile5a model. Emissions of $\mathrm{PM}_{10}$ (both exhaust and brakewear/tirewear) for GVs and diesel vehicles are calculated by using EPA's PART5 model. We estimated $\mathrm{CH}_{4}$ emission for GVs and diesel vehicles by taking the difference between $\mathrm{HC}$ emissions and NMHC emissions, both of which we calculated with the Mobile5a model. Emissions of $\mathrm{N}_{2} \mathrm{O}$ for $\mathrm{GVs}$ and diesel vehicles are adopted from Delucchi (1993).

Emissions from other vehicle types are calculated from emissions of baseline GVs and emission change rates of other vehicle types relative to baseline GVs. Table 9 presents the default values of emission change rates used in the GREET model. Changes in emissions of criteria pollutants for CNG, M85, M100, LPG, E85, and E100 vehicles are based on information presented in Wang et al. (1993). Changes in emissions of $\mathrm{CH}_{4}$ and $\mathrm{N}_{2} \mathrm{O}$ for these vehicle types are based on information presented in Delucchi (1993). Vehicle operation emissions of EVs and HEVs powered by grid electricity are assumed to be zero. Emissions of exhaust VOCs, $\mathrm{CO}$, and $\mathrm{NO}_{\mathrm{x}}$ for $\mathrm{HEVs}$ in the gasoline engine mode are based on information presented in Sperling and Burke (1994). Emissions of evaporative VOCs, exhaust $\mathrm{PM}_{10}, \mathrm{CH}_{4}$, and $\mathrm{N}_{2} \mathrm{O}$ for HEVs in the gasoline engine mode are assumed to be $80 \%$ of those for baseline GVs. We estimated emissions from methanol reformers for methanol FCVs on the basis of data presented in Creveling (1992). Brakewear and tirewear $\mathrm{PM}_{10}$ emissions are assumed to be constant among different vehicle types.

Emissions of $\mathrm{SO}_{\mathrm{x}}$ for each vehicle type are calculated by assuming that all sulfur contained in a given fuel is converted to $\mathrm{SO}_{2}$. Emissions of $\mathrm{CO}_{2}$ for all vehicle types are calculated by subtracting the carbon contained in emissions of VOCs, $\mathrm{CO}$, and $\mathrm{CH}_{4}$ from the carbon contained in a given fuel. For $\mathrm{E} 85$ and $\mathrm{E} 100$ vehicles, the amount of $\mathrm{CO}_{2}$ emissions from the carbon contained in ethanol is treated as zero, because these $\mathrm{CO}_{2}$ emissions originally come from the atmosphere through the photosynthesis process during corn and biomass production.
TABLE 8 Fuel Economy Improvements of 11 Vehicle Types ${ }^{\mathrm{a}}$

Fuel Economy

Improvement

(\% increase in MPG)

Diesel 10

CNG 200

EVs

200

HEVs: gasoline engines 37

Hydrogen FCVs 100

Percentages given are relative to baseline GVs. 
TABLE 9 Emission Changes of Vehicle Operations for Various Vehicle Types ${ }^{a}$

\begin{tabular}{|c|c|c|c|c|c|c|c|}
\hline \multirow[b]{2}{*}{ Vehicle Type } & \multicolumn{7}{|c|}{ Emission Change (\%) } \\
\hline & $\begin{array}{c}\text { Exhaust } \\
\text { VOCs }\end{array}$ & $\begin{array}{c}\text { Evaporative } \\
\text { VOCs }\end{array}$ & $\mathrm{CO}$ & $\mathrm{NO}_{\mathrm{x}}$ & $\begin{array}{c}\text { Exhaust } \\
\text { PM }_{10}\end{array}$ & $\mathrm{CH}_{4}$ & $\mathrm{~N}_{2} \mathrm{O}$ \\
\hline CNG & 45 & 0 & 60 & 95 & 0 & 2,000 & 100 \\
\hline M85 & 85 & 35 & 85 & 95 & 10 & 65 & 100 \\
\hline M:100 & 75 & 35 & 80 & 90 & 0 & 50 & 100 \\
\hline LPG & 55 & 0 & 70 & 95 & 0 & 100 & 100 \\
\hline E85 & 85 & 35 & 85 & 95 & 10 & 65 & 100 \\
\hline E100 & 75 & 35 & 80 & 90 & 0 & 50 & 100 \\
\hline EVs & 0 & 0 & 0 & 0 & 0 & 0 & 0 \\
\hline HEVs: grid electricity & 0 & 0 & 0 & 0 & 0 & 0 & 0 \\
\hline HEVs: gasoline engines & 16 & 80 & 50 & 100 & 80 & 80 & 80 \\
\hline Hydrogen FCVs & 0 & 0 & 0 & 0 & 0 & 0 & 0 \\
\hline Methanol FCVs & 10 & 35 & 10 & 10 & 0 & 0 & 0 \\
\hline
\end{tabular}

a Values represent percent of emissions from baseline GVs. 


\section{MODEL LAYOUT}

The GREET model, developed as a multi-dimensional spreadsheet model in Microsoft Excel 5.0, consists of 12 sheets: Emn_Factors, Fuel_Specs, Petroleum, NG, Landfill_Gas, Biomass, Coal, Uranium, Electricity, Vehicles, Results, and Graphs. Figure 2 shows the information flow diagram of the GREET model. Upstream emissions and energy use are calculated in Petroleum, NG, Landfill_Gas, Biomass, Coal, Uranium, and Electricity by using data contained in Emn_Factors and Fuel_Specs. Emissions and energy use during vehicle operations are calculated in Vehicles; fuel-cycle emissions and energy use are calculated in Results; and graphic presentations of calculated fuel-cycle emissions and energy use are shown in Graphs.

Emn-Factors contains emission factors of fuel combustion in $\mathrm{g} / 10^{6} \mathrm{Btu}$ of fuel burned for 38 combinations of combustion technologies and fuels. Emission factors are presented for combustion technologies that burn NG, residual oil, diesel, gasoline, crude, LPG, coal, and woody biomass. These emission factors are used in other sheets to calculate emissions associated with fuel combustion in various fuel-cycle stages. For each technology/fuel combination, emission factors for each of eight pollutants (VOCs, $\mathrm{CO}, \mathrm{NO}_{\mathrm{x}}, \mathrm{PM}_{10}, \mathrm{SO}_{\mathrm{x}}, \mathrm{CH}_{4}, \mathrm{~N}_{2} \mathrm{O}$, and $\mathrm{CO}_{2}$ ) are presented. Emission factors contained in the sheet have been developed primarily from EPA's AP-42 document (EPA 1995). Other sources used for the development of emission factors are presented in the sheet. Emission factors for $\mathrm{CO}_{2}$ are calculated in the GREET model from carbon contained in a given fuel minus carbon contained in VOCs, $\mathrm{CO}$, and $\mathrm{CH}_{4}$ emitted during combustion of the fuel. For the $\mathrm{CO}_{2}$ emission calculation, the sheet lists the carbon ratios of VOCs, $\mathrm{CO}$, and $\mathrm{CH}_{4}$. The emission factors of $\mathrm{SO}_{\mathrm{x}}$ for combustion of $\mathrm{NG}$, gasoline, crude, and LPG are calculated in the model by assuming that all sulfur contained in these fuels is converted to $\mathrm{SO}_{2}$.

The Fuel_Specs sheet contains the following specifications: low heat value, high heat value, fuel density, sulfur content, and carbon content for the fuels included in the GREET model (crude, conventional gasoline, RFG, LSD, residual oil, methanol, ethanol, LPG, liquid hydrogen, MTBE, ETBE, NG liquids, NG, gaseous hydrogen, coal, woody biomass, and herbaceous biomass). The sheet contains GWPs for the GHGs used in the GREET model; the GWPs are used to combine emissions of GHGs together to calculate $\mathrm{CO}_{2}$-equivalent $\mathrm{GHG}$ emissions. On the basis of the IPCC report (IPCC 1995), the GWPs are assumed to be 1 for $\mathrm{CO}_{2}, 21$ for $\mathrm{CH}_{4}$, and 310 for $\mathrm{N}_{2} \mathrm{O}$.

The seven upstream emissions and energy sheets (Petroleum, NG, Landfill_Gas, Biomass, Coal, Uranium, and Electricity) follow the same calculation logistics described above (Figure 3). For each upstream stage, the model assumes input parameters of fuel combustion technology shares, energy efficiencies, in-basin and out-of-basin emission shares, and energy source shares. Energy consumption (by energy source) is calculated by using assumed energy efficiencies and energy 


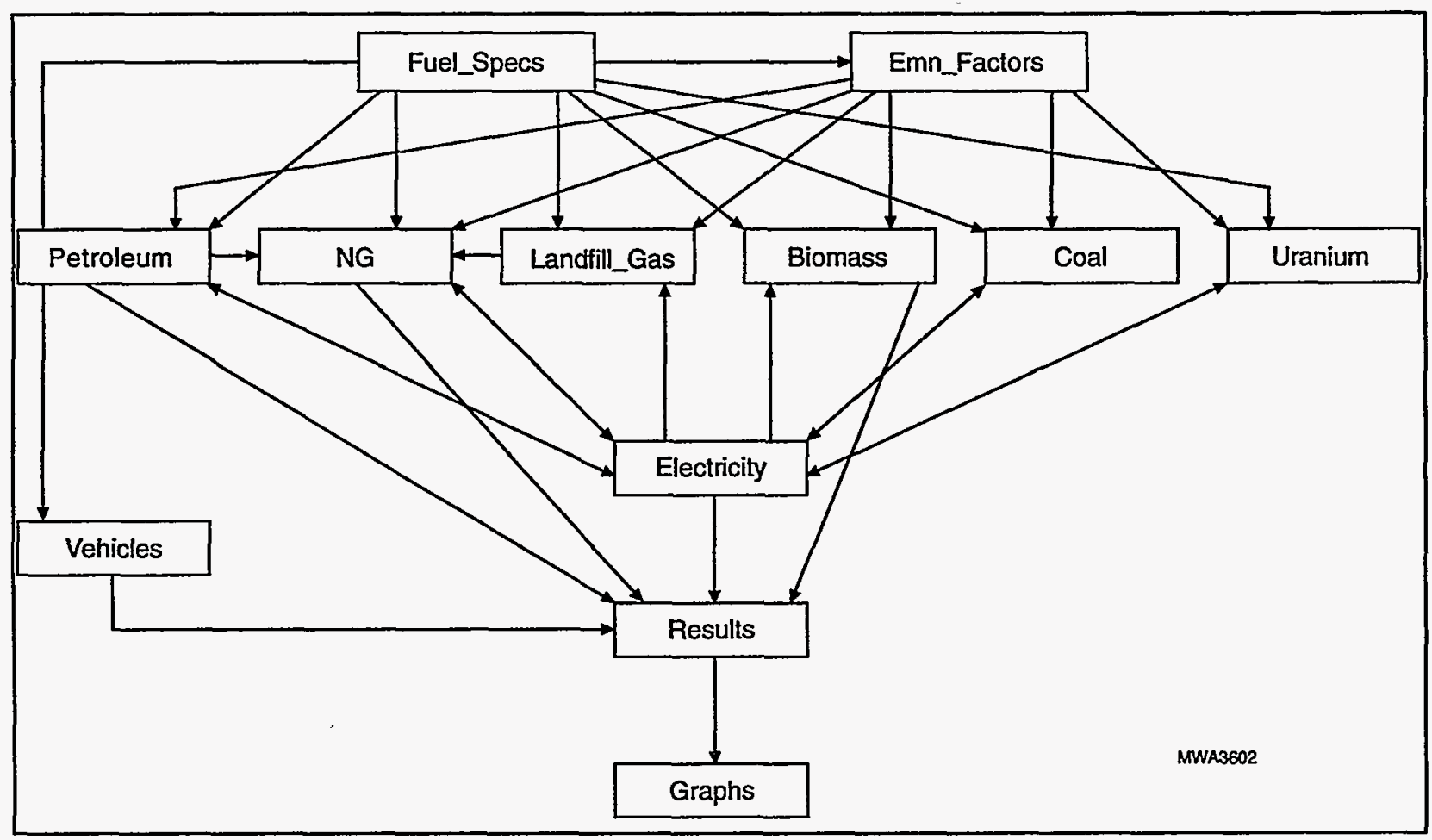

FIGURE 2 Flow Diagram of the GREET Model

source shares. Emissions are calculated from energy consumption (by source), combustion technology shares, and emission factors contained in Emn-Factors. Emissions and energy use in all locations are summarized, and in-basin emissions of the five criteria pollutants are calculated by considering in-basin and out-of-basin emission shares.

The Petroleum sheet contains four fuel cycles (petroleum to RFG, LSD, and residual oil); the NG sheet contains four cycles (NG to CNG, methanol, LPG, and hydrogen); the Landfill_Gas sheet contains one cycle (landfill gases to methanol); and the Biomass sheet contains three cycles (corn, woody biomass, and herbaceous biomass to ethanol). The Coal and Uranium sheets calculate emissions from coal mining to coal at power plants and from uranium mining to uranium at power plants. The Electricity spreadsheet calculates energy use and emissions generated during electricity production for a given electric generation mix and accounts for energy use and emissions during upstream stages of production for residual oil, NG, coal, and uranium.

The Vehicles sheet calculates energy use and emissions of vehicle operations. The Results sheet calculates Btu/mi energy use and $\mathrm{g} / \mathrm{mi}$ emissions for the whole fuel cycle - from primary energy recovery to vehicle operations. Reductions of per-mile energy use and emissions by various vehicle types are calculated relative to baseline GVs. The sheet also presents the allocation of fuelcycle energy use and emissions among primary energy production, fuel production, and vehicle operations. The Graphs sheet graphically presents the allocation of energy use and emissions among primary energy production, fuel production, and vehicle operations and the reductions in energy use and emissions by various vehicle technologies. 


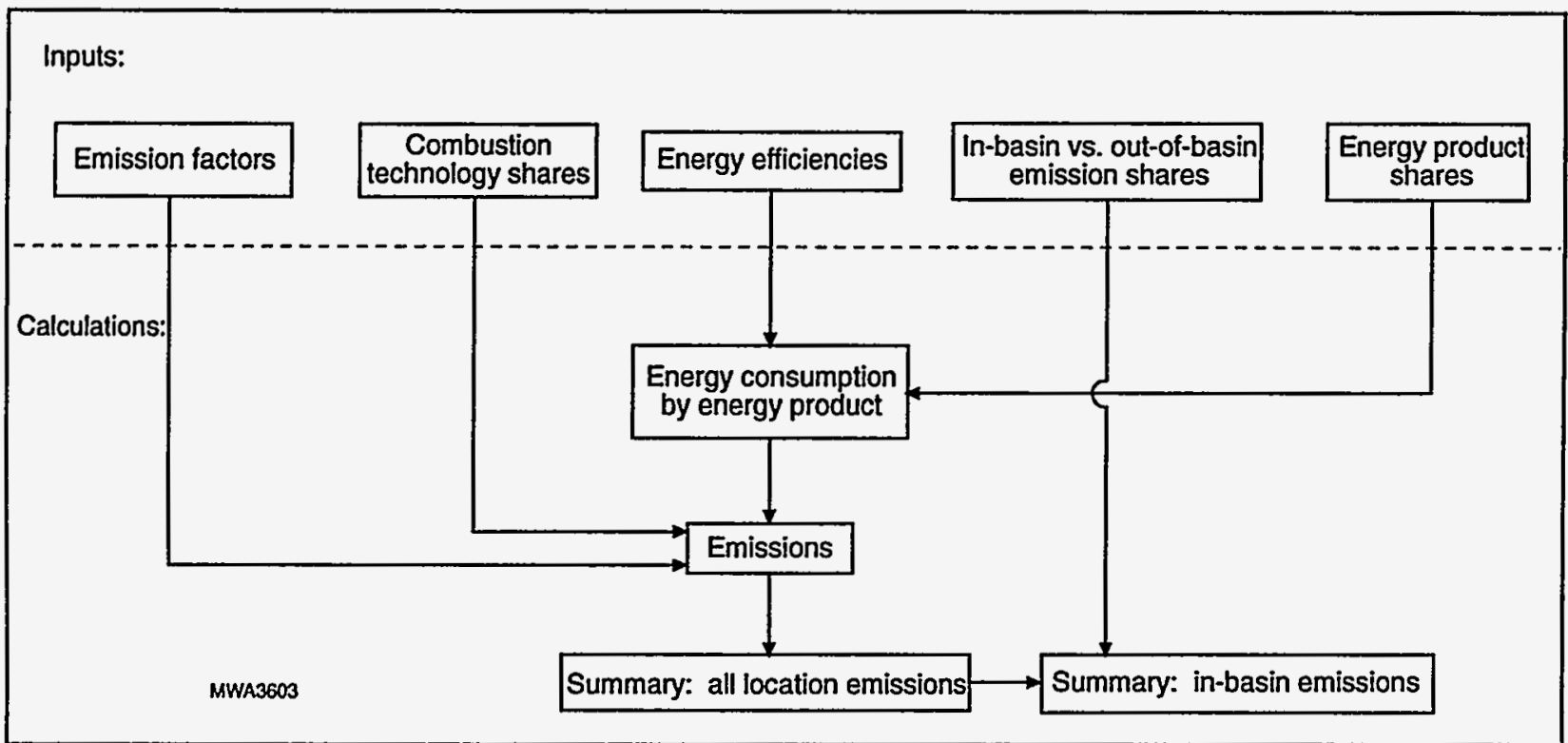

FIGURE 3 Calculation Logic of Upstream Emissions and Energy Use in the GREET Model

Within the GREET model, some cells present default assumptions used for fuel-cycle energy and emission calculations, while others are logic calculations. Users have the option to change any of the default assumptions. The cells that contain critical assumptions are shaded so that users can easily distinguish the critical assumptions from logic calculations. 


\section{ENERGY USE AND EMISSIONS RESULTS}

This section presents the energy use and emissions results for various vehicle technologies, as calculated by using the GREET model. In calculating fuel-cycle emissions, a 2000 model-year (MY) passenger car is assumed. We have also assumed that the baseline 2000-MY car fueled with RFG meets federal Tier 1 standards. While many of the assumed vehicle technologies for the $2000 \mathrm{MY}$ are mature, others - including EVs, HEVs, and FCVs - are not. Immature fuel production technologies include woody biomass to ethanol and herbaceous biomass to ethanol.

To approximate life-cycle emissions for the assumed 2000-MY car, fuel-cycle emissions are calculated in calendar year 2005. By 2005, the 2000-MY car should accumulate about half of its lifetime vehicle miles traveled (VMT). Emissions from the 2000-MY cars in 2005, then, represent the approximate average of the car's lifetime emissions. For HEVs, we assumed that half of their vehicle miles are traveled using energy generated from the on-board gasoline engine, and the other half with grid electricity. Even in 2005, combustion technologies both with and without emission controls can be applied to many upstream stages. Where uncontrolled technologies are applicable, we assumed that $80 \%$ of combustion technologies are controlled and the remaining $20 \%$ are uncontrolled. Table 10 presents calculated per-mile energy use and emissions for all vehicle technologies included in the GREET model. Note that in the table, a negative number indicates an emissions saving credit.

Figures 4 through 12 show changes in fuel-cycle energy use and emissions of various transportation fuels relative to those of RFG. Data for these figures are presented in tabular form in the appendix. Figure 4 shows changes in fuel-cycle total energy use. Use of ethanol and NGbased methanol in internal combustion engines causes a 15-35\% increase in total energy use. These increases are caused primarily by the significant amount of energy lost during ethanol and methanol production. On the other hand, use of FCVs fueled with methanol or hydrogen; HEVs; EVs; and internal combustion engines fueled with landfill gas-based methanol, CNG, LPG, and clean diesel results in decreases in fuel-cycle total energy consumption. Large decreases in energy use result from using FCVs, HEVs, and EVs. The decreases in energy use for CNG, LPG, and landfill gasbased methanol are caused mainly by the high conversion efficiencies during production of these fuels. The decreases in energy use for diesel, EVs, HEVs, and FCVs are caused by the high energy efficiencies of these vehicle technologies.

Figure 5 presents changes in fossil fuel consumption (by use) for each fuel or vehicle type. Fossil fuel consumption here includes consumption of petroleum, NG, and coal. With the exception of NG-based methanol, use of other fuels or vehicle types results in decreased fossil fuel consumption. The largest reductions in fossil fuel consumption occur when landfill gas-based methanol and herbaceous biomass-based ethanol are used, simply because of the non-fossil feedstocks used to produce these fuels. Use of HEVs, EVs, and corn-based ethanol reduces fossil fuel consumption only moderately. Note that use of woody biomass-based E100 helps achieve a greater-than-100\% reduction in fossil fuel use; this is because the electricity credit produced from converting woody biomass to ethanol saves more fossil fuel than is used for other fuel-cycle activities. 
TABLE 10 Fuel-Cycle Energy Use and Emissions of a 2000 Model Year Car in 2005

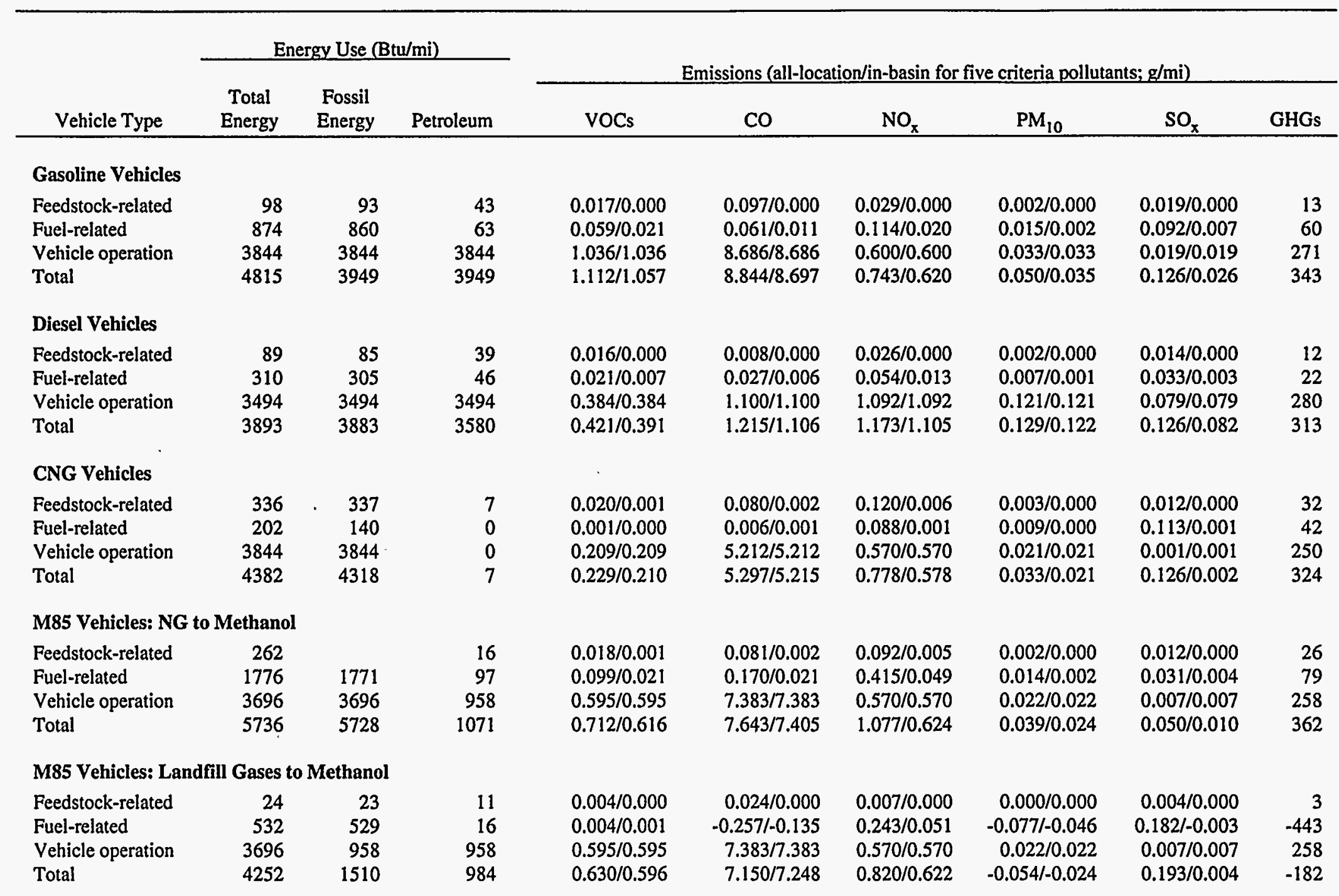




\section{TABLE 10 (Cont.)}

\begin{tabular}{|c|c|c|c|c|c|c|c|c|c|}
\hline \multirow[b]{3}{*}{ Vehicle Type } & \multicolumn{3}{|c|}{ Energy Use (Btu/mi) } & & & & & & \\
\hline & \multirow[b]{2}{*}{$\begin{array}{c}\text { Total } \\
\text { Energy }\end{array}$} & \multirow[b]{2}{*}{$\begin{array}{c}\text { Fossil } \\
\text { Energy }\end{array}$} & \multirow[b]{2}{*}{ Petroleum } & \multicolumn{6}{|c|}{ Emissions (all-location/in-basin for five criteria pollutants; $\mathrm{g} / \mathrm{mi}$ ) } \\
\hline & & & & VOCs & $\mathrm{CO}$ & $\mathrm{NO}_{x}$ & $\mathrm{PM}_{10}$ & $\mathrm{SO}_{x}$ & GHGs \\
\hline \multicolumn{10}{|c|}{ M100 Vehicles: NG to Methanol } \\
\hline Feedstock-related & 320 & 319 & 7 & $0.019 / 0.001$ & $0.76 / 0.002$ & $0.114 / 0.006$ & $0.003 / 0.000$ & $0.011 / 0.000$ & 31 \\
\hline Fuel-related & 2083 & 2081 & 109 & $0.112 / 0.021$ & $0.206 / 0.024$ & $0.517 / 0.059$ & $0.013 / 0.002$ & $0.011 / 0.003$ & 85 \\
\hline Vehicle operation & 3661 & 3661 & 0 & $0.548 / 0.548$ & $6.949 / 6.949$ & $0.540 / 0.540$ & $0.021 / 0.021$ & $0.003 / 0.003$ & 254 \\
\hline Total & 6064 & 6060 & 116 & $0.679 / 0.570$ & $7.213 / 6.975$ & $1.171 / 0.605$ & $0.037 / 0.023$ & $0.025 / 0.005$ & 370 \\
\hline \multicolumn{10}{|c|}{ M100 Vehicles: Landfill Gases to Methanol } \\
\hline Feedstock-related & 0 & 0 & 0 & $0.000 / 0.000$ & $0.000 / 0.000$ & $0.000 / 0.000$ & $0.000 / 0.000$ & $0.000 / 0.000$ & 0 \\
\hline Fuel-related & 420 & 420 & 0 & $-0.014 /-0.006$ & $-0.364 /-0.184$ & $0.287 / 0.062$ & $-0.108 /-0.062$ & $0.213 /-0.006$ & -612 \\
\hline Vehicle operation & 3661 & 0 & 0 & $0.548 / 0.548$ & $6.949 / 6.949$ & $0.540 / 0.540$ & $0.021 / 0.021$ & $0.003 / 0.003$ & 254 \\
\hline Total & 4081 & 420 & 0 & $0.534 / 0.542$ & $6.585 / 6.767$ & $0.827 / 0.602$ & $-0.087 / 0.003$ & $0.216 /-0.003$ & -358 \\
\hline \multicolumn{10}{|l|}{ LPG Vehicles } \\
\hline Feedstock-related & 301 & 299 & 13 & $0.019 / 0.001$ & $0.082 / 0.002$ & $0.106 / 0.005$ & $0.003 / 0.000$ & $0.012 / 0.000$ & 29 \\
\hline Fuel-related & 238 & 235 & 74 & $0.027 / 0.009$ & $0.034 / 0.009$ & $0.082 / 0.021$ & $0.005 / 0.002$ & $0.012 / 0.001$ & 17 \\
\hline Vehicle operation & 3844 & 3844 & 577 & $0.256 / 0.256$ & $6.080 / 6.080$ & $0.570 / 0.570$ & $0.021 / 0.021$ & $0.000 / 0.000$ & 268 \\
\hline Total & 4382 & 4377 & 663 & $0.302 / 0.265$ & $6.196 / 6.091$ & $0.758 / 0.596$ & $0.029 / 0.028$ & $0.024 / 0.001$ & 314 \\
\hline \multicolumn{10}{|c|}{ E85 Vehicles: Corn to Ethanol } \\
\hline Feedstock-related & 587 & 569 & 271 & $0.037 / 0.000$ & $0.149 / 0.000$ & $0.375 / 0.000$ & $0.012 / 0.000$ & $0.043 / 0.000$ & 134 \\
\hline Fuel-related & 1852 & 1804 & 79 & $0.082 / 0.017$ & $0.397 / 0.016$ & $0.400 / 0.031$ & $0.143 / 0.002$ & $0.540 / 0.003$ & 76 \\
\hline Vehicle operation & 3696 & 768 & 768 & $0.595 / 0.595$ & $7.383 / 7.383$ & $0.570 / 0.570$ & $0.022 / 0.022$ & $0.005 / 0.005$ & 46 \\
\hline Total & 6135 & 3142 & 1126 & $0.714 / 0.612$ & $7.929 / 7.399$ & $1.345 / 0.602$ & $0.178 / 0.025$ & $0.588 / 0.008$ & 256 \\
\hline \multicolumn{10}{|c|}{ E85 Vehicles: Woody Biomass to Ethanol } \\
\hline Feedstock-related & 50 & 49 & 24 & $0.005 / 0.000$ & $0.026 / 0.000$ & $0.025 / 0.000$ & $0.001 / 0.000$ & $0.04 / 0.000$ & 9 \\
\hline Fuel-related & 2397 & 73 & 73 & $0.056 / 0.017$ & $0.118 / 0.014$ & $0.125 / 0.028$ & $0.327 / 0.002$ & $-0.104 / 0.002$ & -29 \\
\hline Vehicle operation & 3694 & 768 & 768 & $0.595 / 0.595$ & $7.383 / 7.383$ & $0.570 / 0.570$ & $0.022 / 0.022$ & $0.005 / 0.005$ & 46 \\
\hline Total & 6143 & 890 & 870 & $0.657 / 0.611$ & $7.528 / 7.398$ & $0.722 / 0.598$ & $0.350 / 0.024$ & $-0.095 / 0.007$ & 26 \\
\hline
\end{tabular}


TABLE 10 (Cont.)

\begin{tabular}{|c|c|c|c|c|c|c|c|c|c|}
\hline \multirow[b]{3}{*}{ Vehicle Type } & \multicolumn{3}{|c|}{ Energy Use (Btu/mi) } & & & & & & \\
\hline & \multirow[b]{2}{*}{$\begin{array}{c}\text { Total } \\
\text { Energy }\end{array}$} & \multirow[b]{2}{*}{$\begin{array}{c}\text { Fossil } \\
\text { Energy } \\
\end{array}$} & \multirow[b]{2}{*}{ Petroleum } & \multicolumn{6}{|c|}{ Emissions (all-location/in-basin for five criteria pollutants; $\mathrm{g} / \mathrm{mi}$ ) } \\
\hline & & & & VOCs & $\mathrm{CO}$ & $\mathrm{NO}_{\mathrm{x}}$ & $\mathrm{PM}_{10}$ & $\mathrm{SO}_{\mathrm{x}}$ & GHGs \\
\hline \multicolumn{10}{|c|}{ E85 Vehicles: Herbaceous Biomass to Ethanol } \\
\hline $\begin{array}{l}\text { Feedstock-related } \\
\text { Fuel-related } \\
\text { Vehicle operation } \\
\text { Total }\end{array}$ & $\begin{array}{r}100 \\
1687 \\
3696 \\
5483\end{array}$ & $\begin{array}{r}98 \\
175 \\
768 \\
1040\end{array}$ & $\begin{array}{r}27 \\
79 \\
768 \\
875\end{array}$ & $\begin{array}{l}0.007 / 0.000 \\
0.051 / 0.017 \\
0.595 / 0.595 \\
0.653 / 0.612\end{array}$ & $\begin{array}{l}0.031 / 0.000 \\
0.092 / 0.015 \\
7.383 / 7.383 \\
7.560 / 3.398\end{array}$ & $\begin{array}{l}0.076 / 0.000 \\
0.134 / 0.029 \\
0.570 / 0.570 \\
0.780 / 0.600\end{array}$ & $\begin{array}{l}0.002 / 0.000 \\
0.220 / 0.002 \\
0.022 / 0.022 \\
0.244 / 0.024\end{array}$ & $\begin{array}{r}0.007 / 0.000 \\
-0.026 / 0.002 \\
0.005 / 0.005 \\
-0.013 / 0.008\end{array}$ & $\begin{array}{r}24 \\
0 \\
46 \\
70\end{array}$ \\
\hline \multicolumn{10}{|c|}{ E100 Vehicles: Corn to Ethanol } \\
\hline $\begin{array}{l}\text { Feedstock-related } \\
\text { Fuel-related } \\
\text { Vehicle operation } \\
\text { Total }\end{array}$ & $\begin{array}{r}710 \\
2097 \\
3661 \\
6467\end{array}$ & $\begin{array}{r}689 \\
2041 \\
0 \\
2730\end{array}$ & $\begin{array}{r}338 \\
84 \\
0 \\
422\end{array}$ & $\begin{array}{l}0.042 / 0.000 \\
0.088 / 0.016 \\
0.548 / 0.548 \\
0.679 / 0.564\end{array}$ & $\begin{array}{l}0.162 / 0.000 \\
0.481 / 0.018 \\
6.949 / 6.949 \\
7.592 / 6.967\end{array}$ & $\begin{array}{l}0.462 / 0.000 \\
0.471 / 0.034 \\
0.540 / 0.540 \\
1.473 / 0.574\end{array}$ & $\begin{array}{l}0.015 / 0.000 \\
1.176 / 0.002 \\
0.021 / 0.021 \\
1.212 / 0.023\end{array}$ & $\begin{array}{l}0.050 / 0.000 \\
0.653 / 0.002 \\
0.002 / 0.002 \\
0.704 / 0.004\end{array}$ & $\begin{array}{r}164 \\
81 \\
-10 \\
234\end{array}$ \\
\hline \multicolumn{10}{|c|}{ E100 Vehicles: Woody Biomass to Ethanol } \\
\hline $\begin{array}{l}\text { Feedstock-related } \\
\text { Fuel-related } \\
\text { Vehicle operation } \\
\text { Total }\end{array}$ & $\begin{array}{r}38 \\
2779 \\
3661 \\
6748\end{array}$ & $\begin{array}{r}38 \\
-124 \\
0 \\
-86\end{array}$ & $\begin{array}{r}19 \\
84 \\
0 \\
103\end{array}$ & $\begin{array}{r}0.002 / 0.000 \\
0.056 / 0.016 \\
0.548 / 0.548 \\
0 . / 0.564\end{array}$ & $\begin{array}{l}0.009 / 0.000 \\
0.132 / 0.015 \\
6.949 / 6.949 \\
7.090 / 6.964\end{array}$ & $\begin{array}{l}0.024 / 0.000 \\
0.128 / 0.030 \\
0.540 / 0.540 \\
0.693 / 0.570\end{array}$ & $\begin{array}{l}0.001 / 0.000 \\
0.405 / 0.002 \\
0.021 / 0.021 \\
0.427 / 0.023\end{array}$ & $\begin{array}{r}0.001 / 0.000 \\
-0.153 / 0.000 \\
0.002 / 0.002 \\
-0.150 / 0.002\end{array}$ & $\begin{array}{r}8 \\
-51 \\
-10 \\
-54\end{array}$ \\
\hline \multicolumn{10}{|c|}{ E100 Vehicles: Herbaceous Biomass to Ethanol } \\
\hline $\begin{array}{l}\text { Feedstock-related } \\
\text { Fuel-related } \\
\text { Vehicle operation } \\
\text { Total }\end{array}$ & $\begin{array}{r}101 \\
1891 \\
3661 \\
5653\end{array}$ & $\begin{array}{r}99 \\
4 \\
0 \\
102\end{array}$ & $\begin{array}{r}23 \\
84 \\
0 \\
107\end{array}$ & $\begin{array}{l}0.005 / 0.000 \\
0.049 / 0.016 \\
0.548 / 0.548 \\
0.602 / 0.564\end{array}$ & $\begin{array}{l}0.015 / 0.000 \\
0.099 / 0.016 \\
6.949 / 6.949 \\
7.063 / 6.965\end{array}$ & $\begin{array}{l}0.088 / 0.001 \\
0.139 / 0.031 \\
0.540 / 0.540 \\
0.766 / 0.572\end{array}$ & $\begin{array}{l}0.002 / 0.000 \\
0.272 / 0.002 \\
0.021 / 0.021 \\
0.294 / 0.023\end{array}$ & $\begin{array}{r}0.005 / 0.000 \\
-0.055 / 0.001 \\
0.002 / 0.002 \\
-0.048 / 0.003\end{array}$ & $\begin{array}{r}27 \\
-15 \\
-10 \\
2\end{array}$ \\
\hline \multicolumn{10}{|c|}{ Electric Vehicles: U.S. Generation Mix } \\
\hline $\begin{array}{l}\text { Feedstock-related } \\
\text { Fuel-related } \\
\text { Vehicle operation } \\
\text { Total }\end{array}$ & $\begin{array}{r}120 \\
3471 \\
0 \\
3590\end{array}$ & $\begin{array}{r}107 \\
2697 \\
0 \\
2803\end{array}$ & $\begin{array}{r}24 \\
38 \\
0 \\
163\end{array}$ & $\begin{array}{l}0.012 / 0.000 \\
0.004 / 0.000 \\
0.000 / 0.000 \\
0.016 / 0.000\end{array}$ & $\begin{array}{l}0.034 / 0.001 \\
0.039 / 0.005 \\
0.000 / 0.000 \\
0.074 / 0.006\end{array}$ & $\begin{array}{r}0.057 / 0.001 \\
0.557 / 0.009 \\
0.0000 .000 \\
0.613 / 0.010\end{array}$ & $\begin{array}{l}0.007 / 0.000 \\
0.058 / 0.001 \\
0.021 / 0.021 \\
0.086 / 0.022\end{array}$ & $\begin{array}{l}0.037 / 0.000 \\
0.713 / 0.003 \\
0.000 / 0.000 \\
0.750 / 0.004\end{array}$ & $\begin{array}{r}31 \\
265 \\
0 \\
296\end{array}$ \\
\hline
\end{tabular}


TABLE 10 (Cont.)

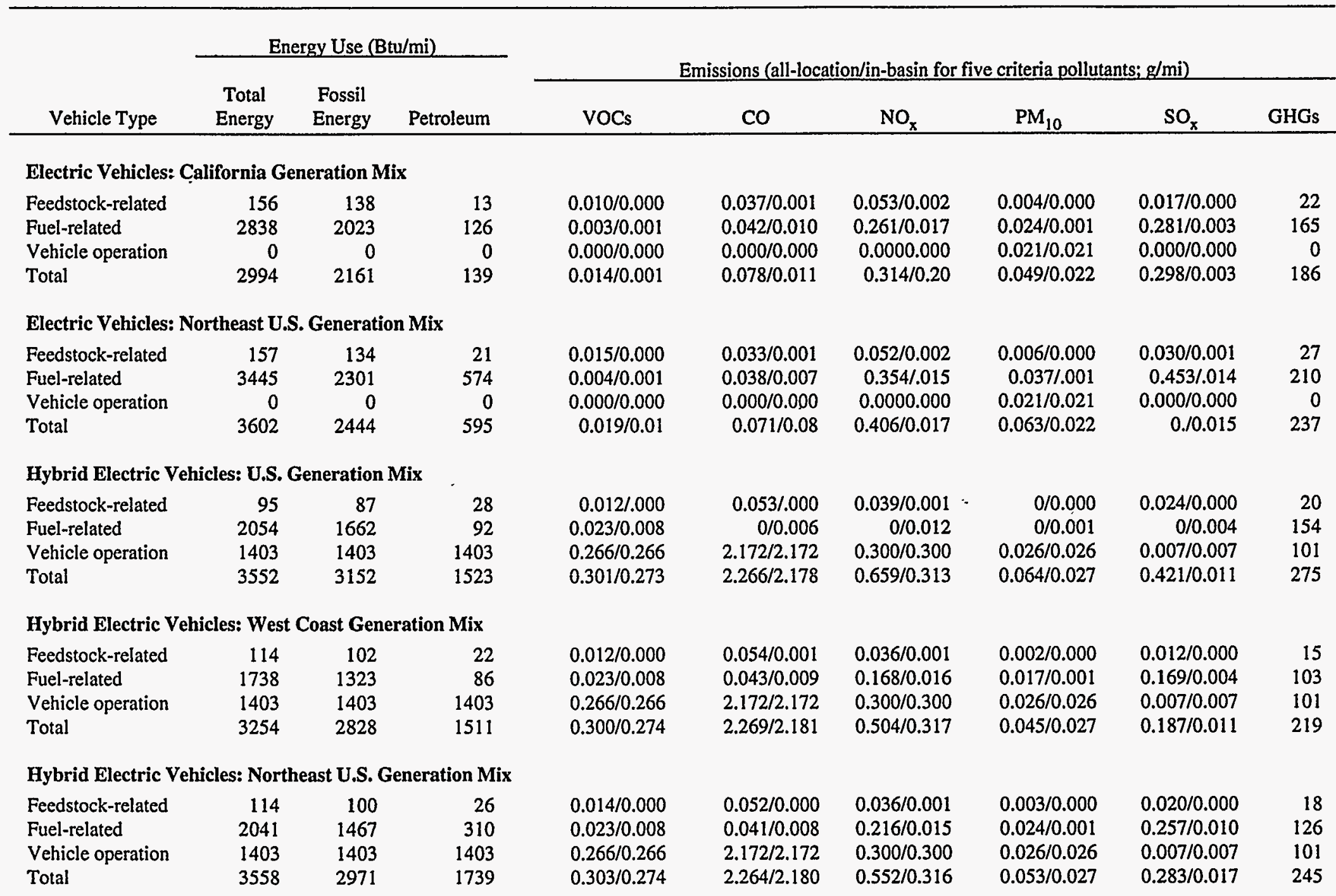


TABLE 10 (Cont.)

\begin{tabular}{|c|c|c|c|c|c|c|c|c|c|}
\hline \multirow[b]{3}{*}{ Vehicle Type } & \multicolumn{3}{|c|}{ Energy Use (Btu/mi) } & & & & & & \\
\hline & \multirow[b]{2}{*}{$\begin{array}{c}\text { Total } \\
\text { Energy }\end{array}$} & \multirow[b]{2}{*}{$\begin{array}{c}\text { Fossil } \\
\text { Energy }\end{array}$} & \multirow[b]{2}{*}{ Petroleum } & \multicolumn{6}{|c|}{ Emissions (all-location/in-basin for five criteria pollutants; $\mathrm{g} / \mathrm{mi}$ ) } \\
\hline & & & & VOCs & $\mathrm{CO}$ & $\mathrm{NO}_{x}$ & $\mathrm{PM}_{10}$ & $\mathrm{SO}_{\mathrm{x}}$ & GHGs \\
\hline \multicolumn{10}{|c|}{ Hydrogen Fuel-Cell Vehicles: NG to Hydrogen } \\
\hline Feedstock-related & 168 & 167 & 4 & $0.010 / 0.000$ & $0.040 / 0.001$ & $0.060 / 0.003$ & $0.001 / 0.000$ & $0.006 / 0.000$ & 16 \\
\hline Fuel-related & 1829 & 1828 & 101 & $0.091 / 0.015$ & $0.211 / 0.033$ & $0.510 / 0.075$ & $0.016 / 0.004$ & $0.005 / 0.001$ & 229 \\
\hline Vehicle operation & 1922 & 1922 & 0 & $0.000 / 0.000$ & $0.000 / 0.000$ & 0.0000 .000 & $0.021 / 0.021$ & $0.000 / 0.000$ & 0 \\
\hline Total & 3919 & 3917 & 105 & $0.101 / 0.016$ & $0.251 / 0.034$ & $0.570 / 0.078$ & $0.039 / 0.025$ & $0.011 / 0.011$ & 245 \\
\hline \multicolumn{10}{|c|}{ Methanol Fuel-Cell Vehicles: NG to Methanol } \\
\hline Feedstock-related & 218 & 217 & 5 & $0.013 / 0.001$ & $0.052 / 0.002$ & $0.078 / 0.004$ & $0.002 / 0.000$ & $0.008 / 0.000$ & 21 \\
\hline Fuel-related & 1420 & 1419 & 74 & $0.077 / 0.014$ & $0.141 / 0.016$ & $0.352 / 0.040$ & $0.009 / 0.002$ & $0.007 / 0.002$ & 58 \\
\hline Vehicle operation & 2496 & 2496 & 0 & $0.246 / 0.246$ & $0.869 / 0.869$ & $0.060 / 0.060$ & $0.021 / 0.021$ & $0.002 / 0.002$ & 179 \\
\hline Total & 4135 & 4132 & 79 & $0.336 / 0.261$ & $1.061 / 0.887$ & $0.490 / 0.104$ & $0.032 / 0.023$ & $0.017 / 0.004$ & 258 \\
\hline \multicolumn{10}{|c|}{ Methanol Fuel-Cell Vehicles: Landfill Gases to Methanol } \\
\hline Feedstock-related & 0 & 0 & 0 & $0.000 / 0.000$ & $0.000 / 0.000$ & $0.000 / 0.000$ & $0.000 / 0.000$ & $0.000 / .000$ & 0 \\
\hline Fuel-related & 287 & 287 & 0 & $-0.01 /-0.004$ & $-0.248 /-.125$ & $0.195 / 0.042$ & $-0.073 /-.042$ & $0.145 /-0.004$ & -418 \\
\hline Vehicle operation & 2496 & 0 & 0 & $0.246 / 0.246$ & $0.869 / 0.869$ & $0.060 / 0.060$ & $0.021 / 0.021$ & $0.002 / 0.002$ & 179 \\
\hline Total & 2782 & 287 & 0 & $0.237 / 0.242$ & $0.620 / 0.743$ & $0.255 / 0.102$ & $-0.052 /-.021$ & $0.147 /-0.003$ & -238 \\
\hline
\end{tabular}




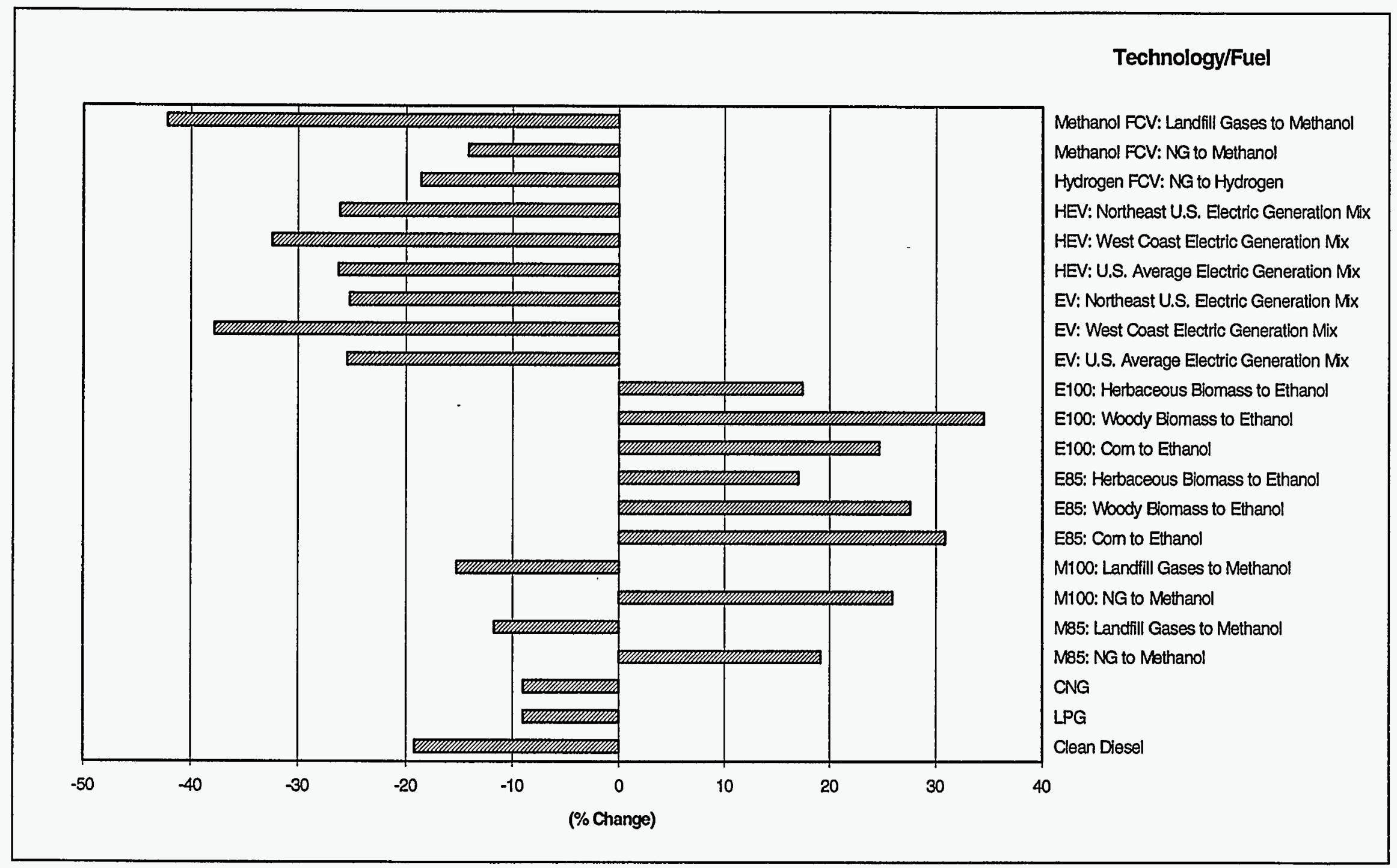

FIGURE 4 Change in Fuel-Cycle Total Energy Use 


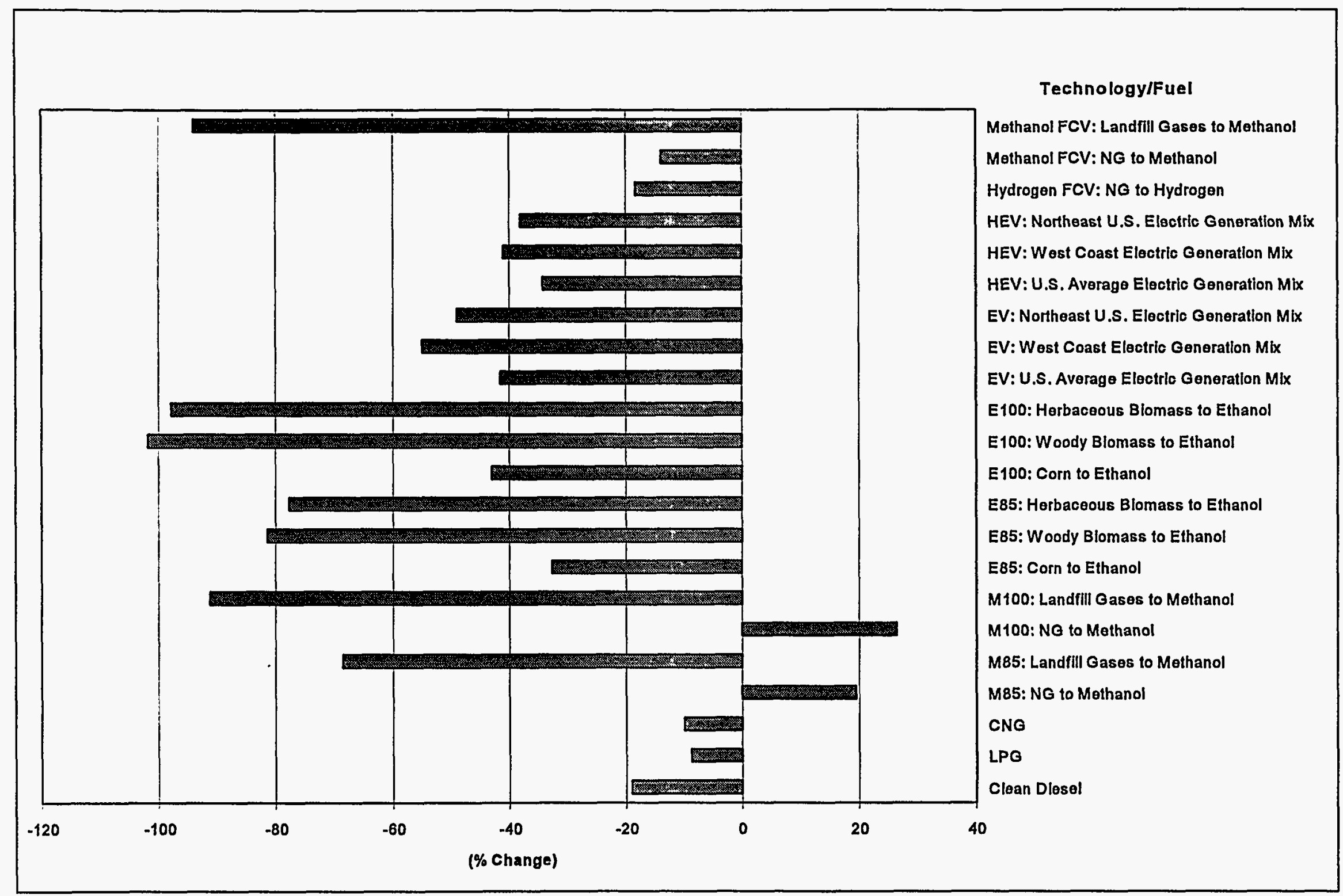

Note: The greater-than-100\% reduction for converting woody biomass to ethanol is a result of fossil fuel savings from the electricity credit earned at ethanol plants.

FIGURE 5 Change in Fuel-Cycle Fossil Fuel Use (relative to RFG) 
Technology/Fuel

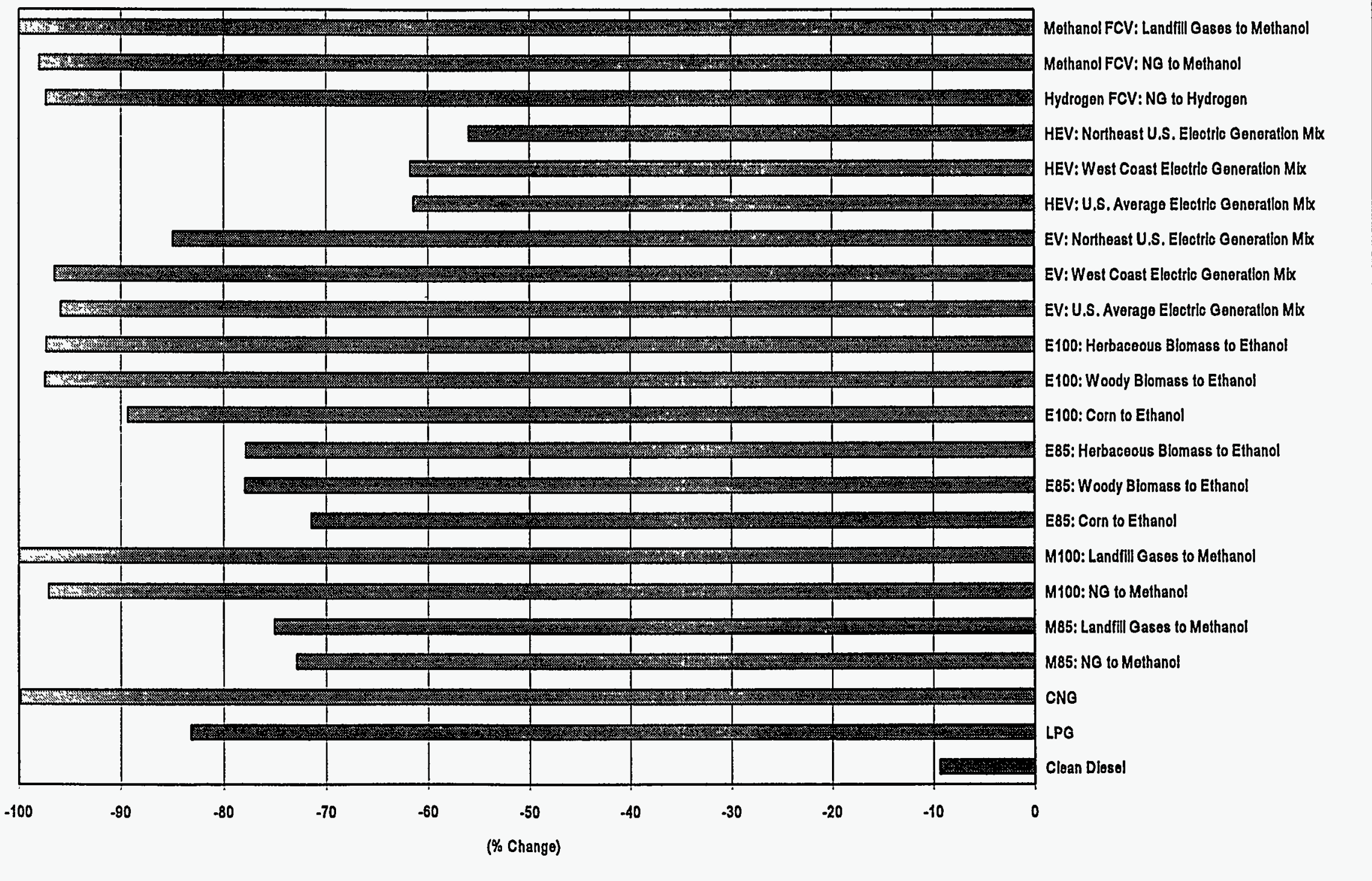

FIGURE 6 Change in Fuel-Cycle Petroleum Use (relative to RFG) 


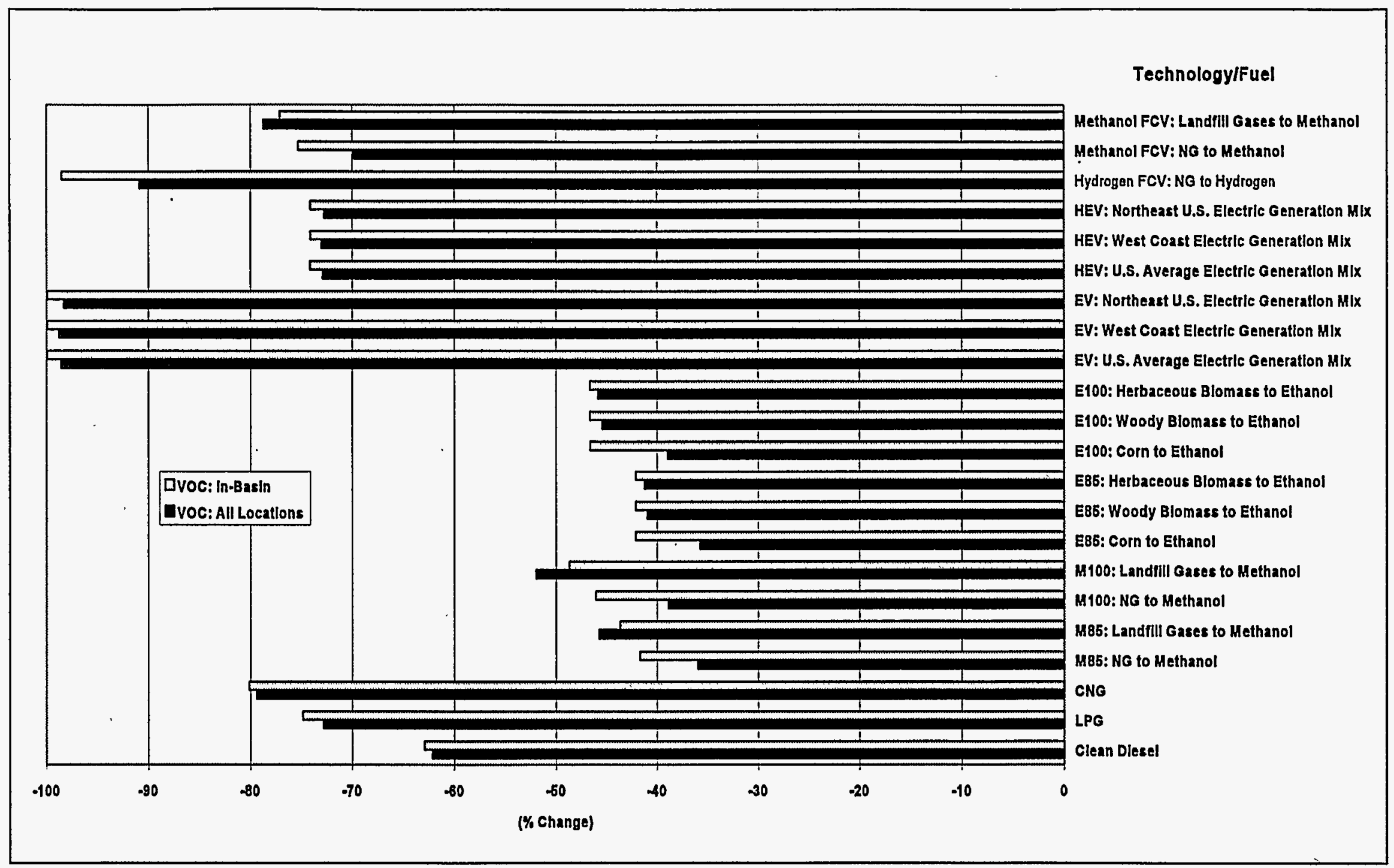

FIGURE 7 Change in Fuel-Cycle VOC Emissions (relative to RFG) 


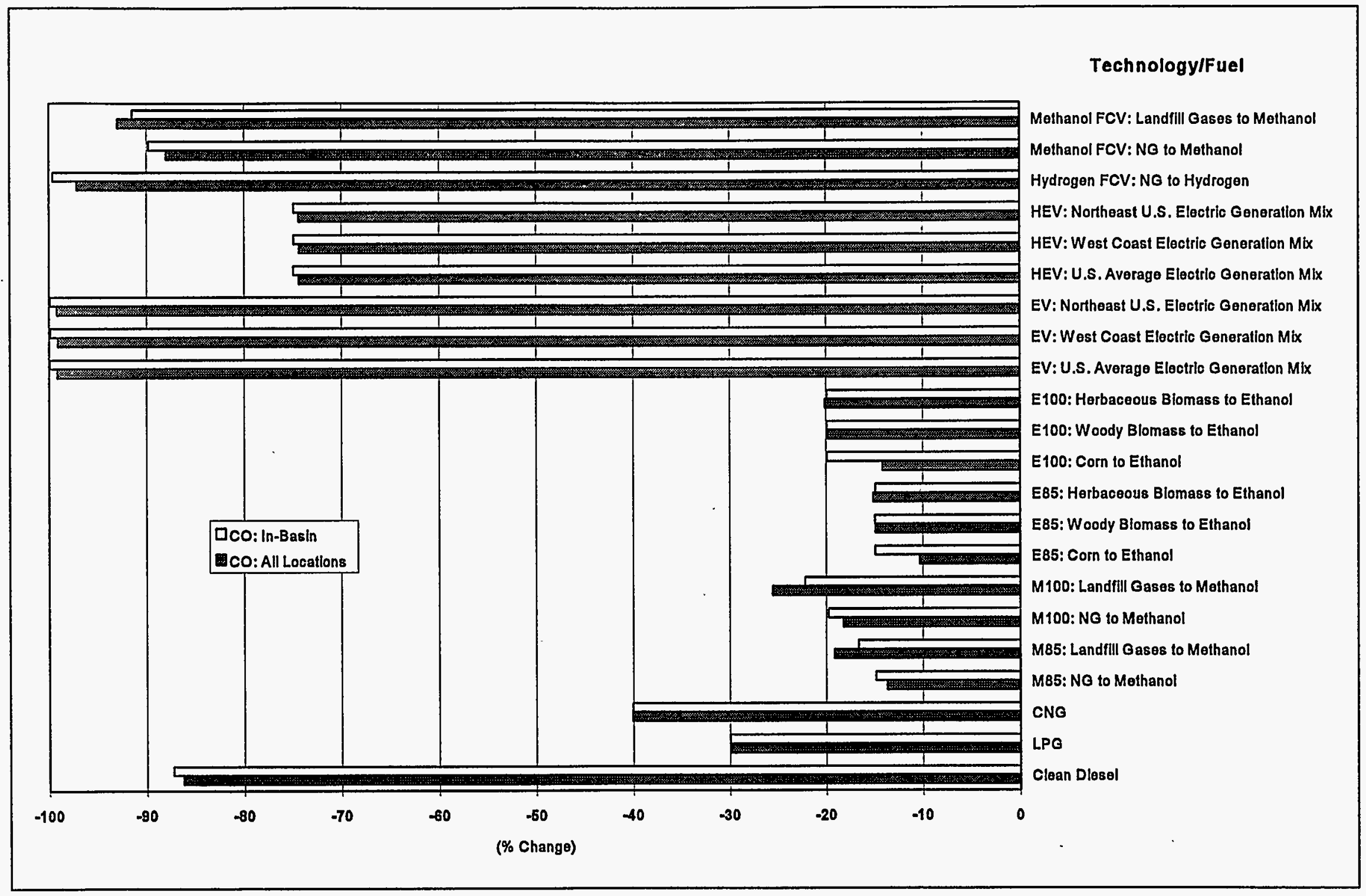

FIGURE 8 Change in Fuel-Cycle CO Emissions (relative to RFG) 


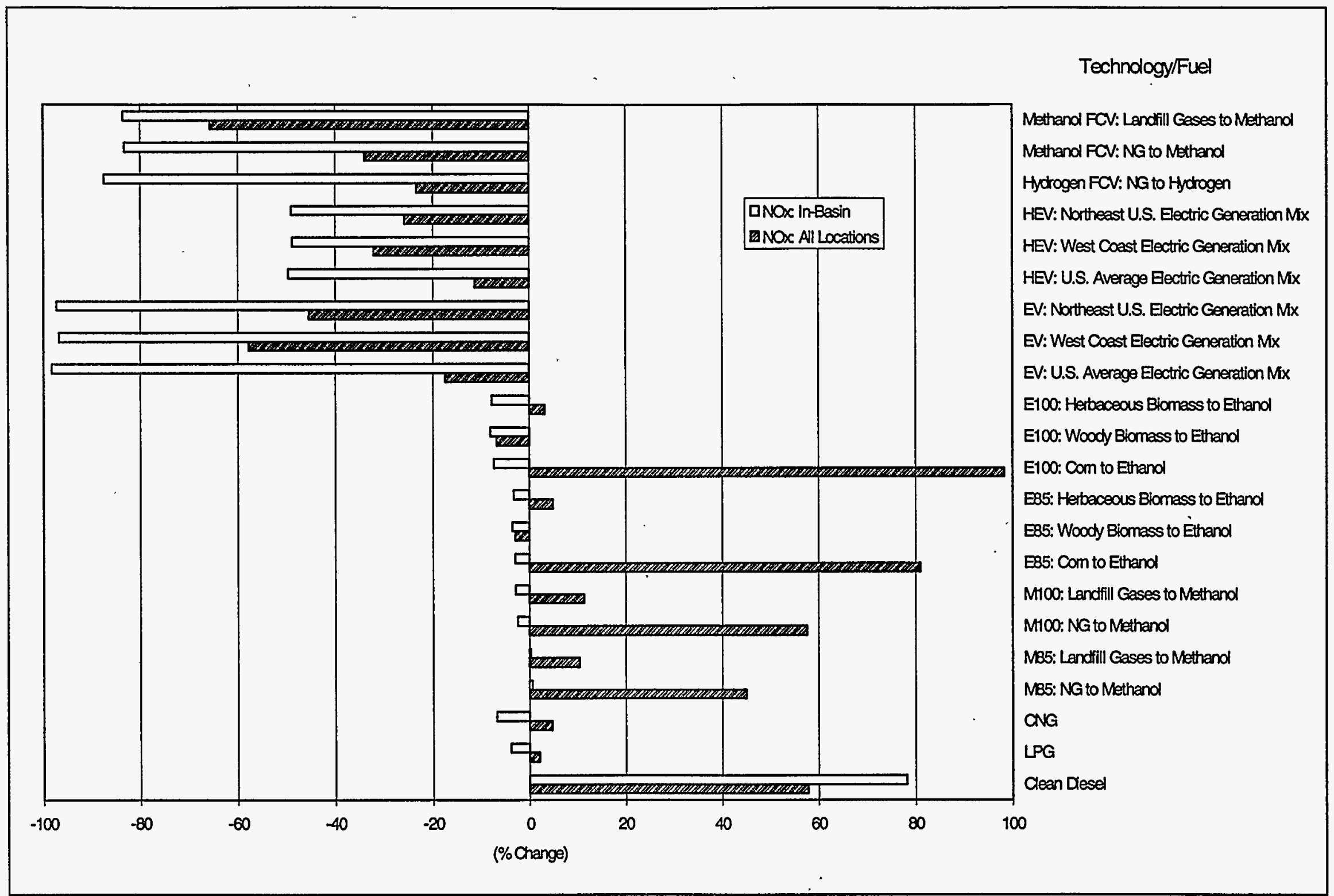

FIGURE 9 Change in Fuel-Cycle $\mathrm{NO}_{\mathbf{x}}$ Emissions (relative to RFG) 


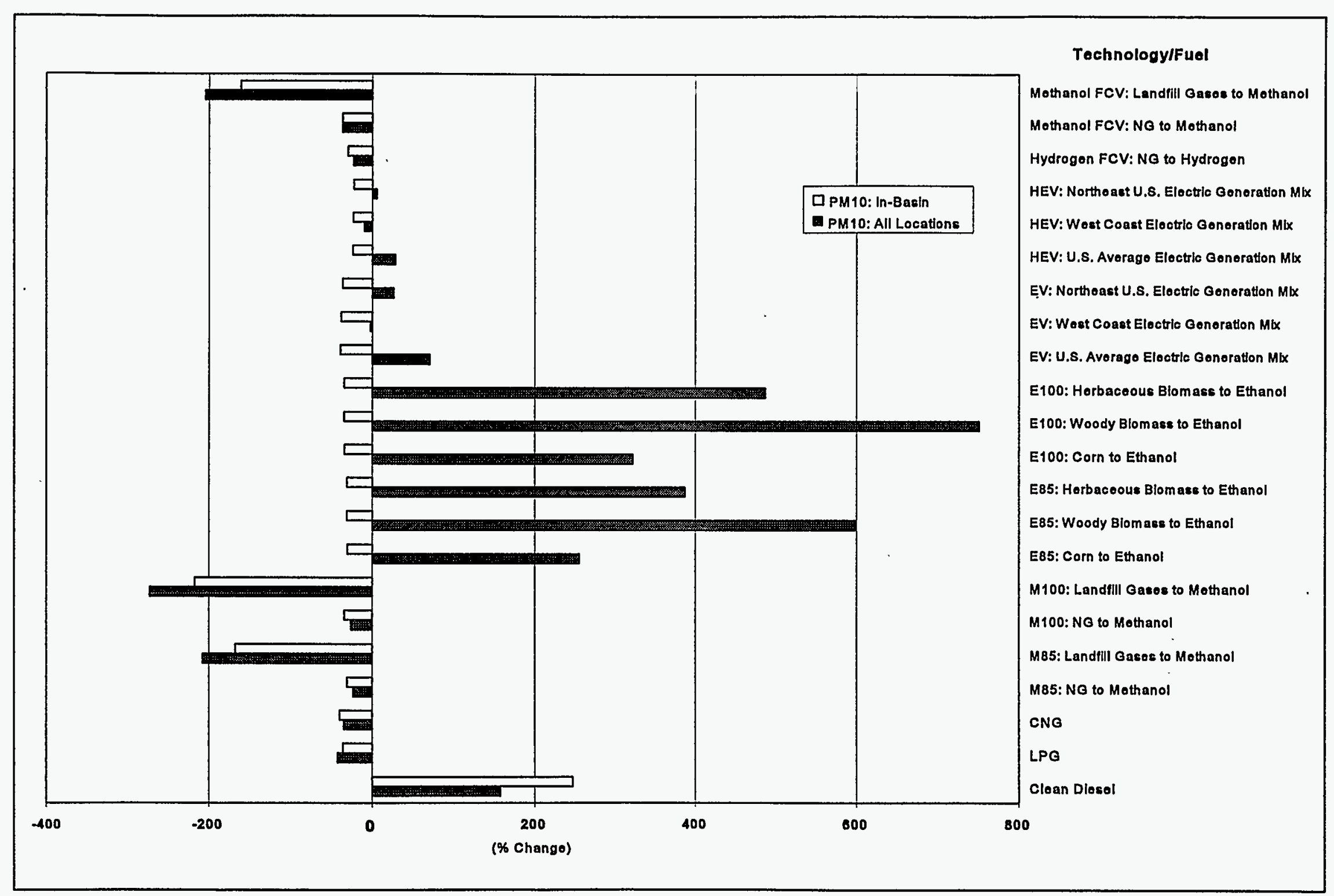

Note: The greater-than-100\% reductions for converting landfill gases to methanol are a result of eliminating the $\mathrm{PM}_{10}$ emissions that would otherwise be generated by burning landfill gases directly.

FIGURE 10 Change in Fuel-Cycle PM $_{10}$ Emissions (relative to RFG) 


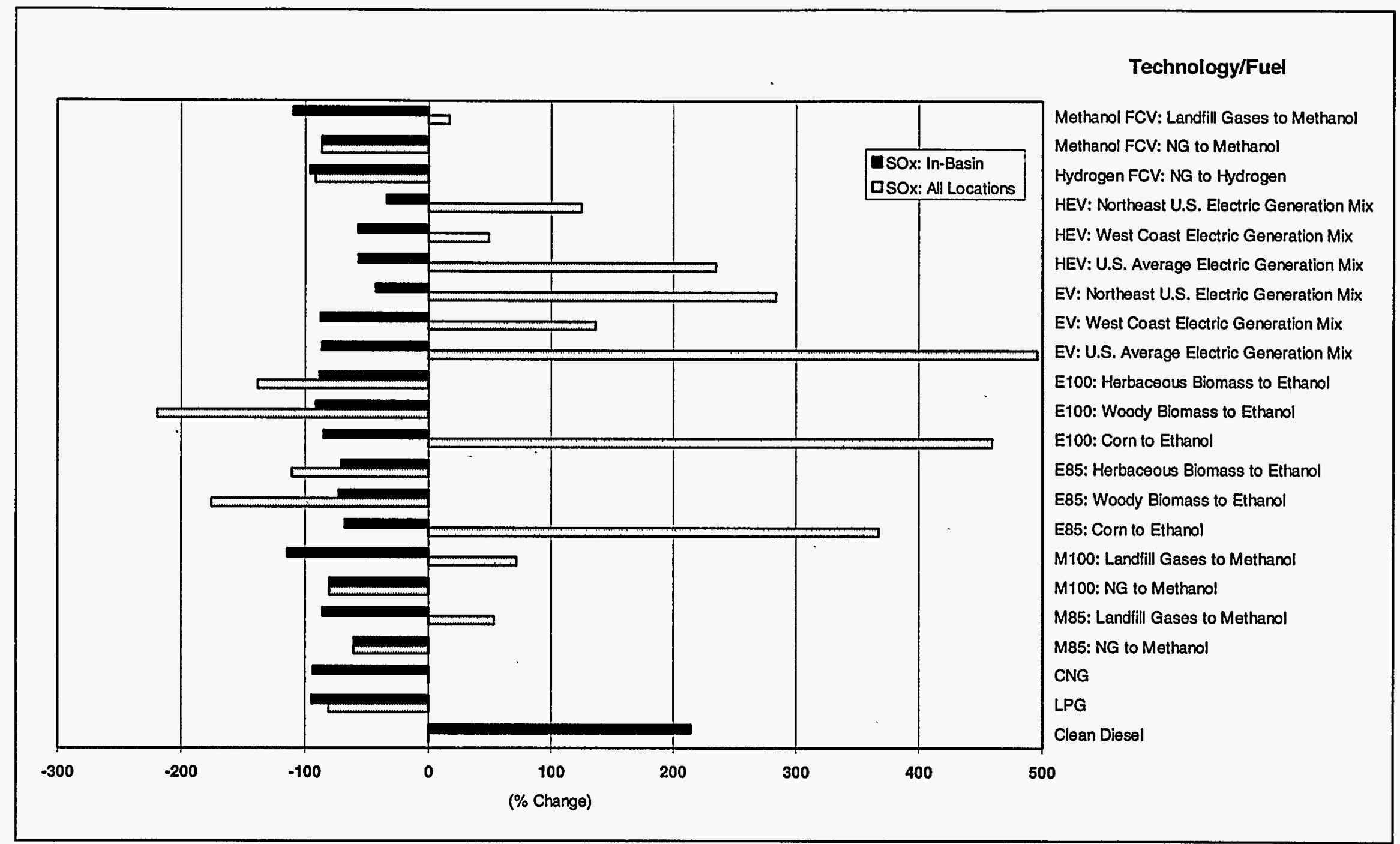

Note: The greater-than-100\% reductions for converting landfill gases to methanol are a result of eliminating the $\mathrm{SO}_{\mathrm{x}}$ emissions that would otherwise be generated by burning landfill gases directly. The greater-than-100\% reductions for converting biomass to ethanol are a result of the power plant $\mathrm{SO}_{\mathrm{x}}$ emissions eliminated by the electricity credit earned at ethanol plants.

FIGURE 11 Change in Fuel-Cycle $\mathrm{SO}_{\mathrm{x}}$ Emissions (relative to RFG) 


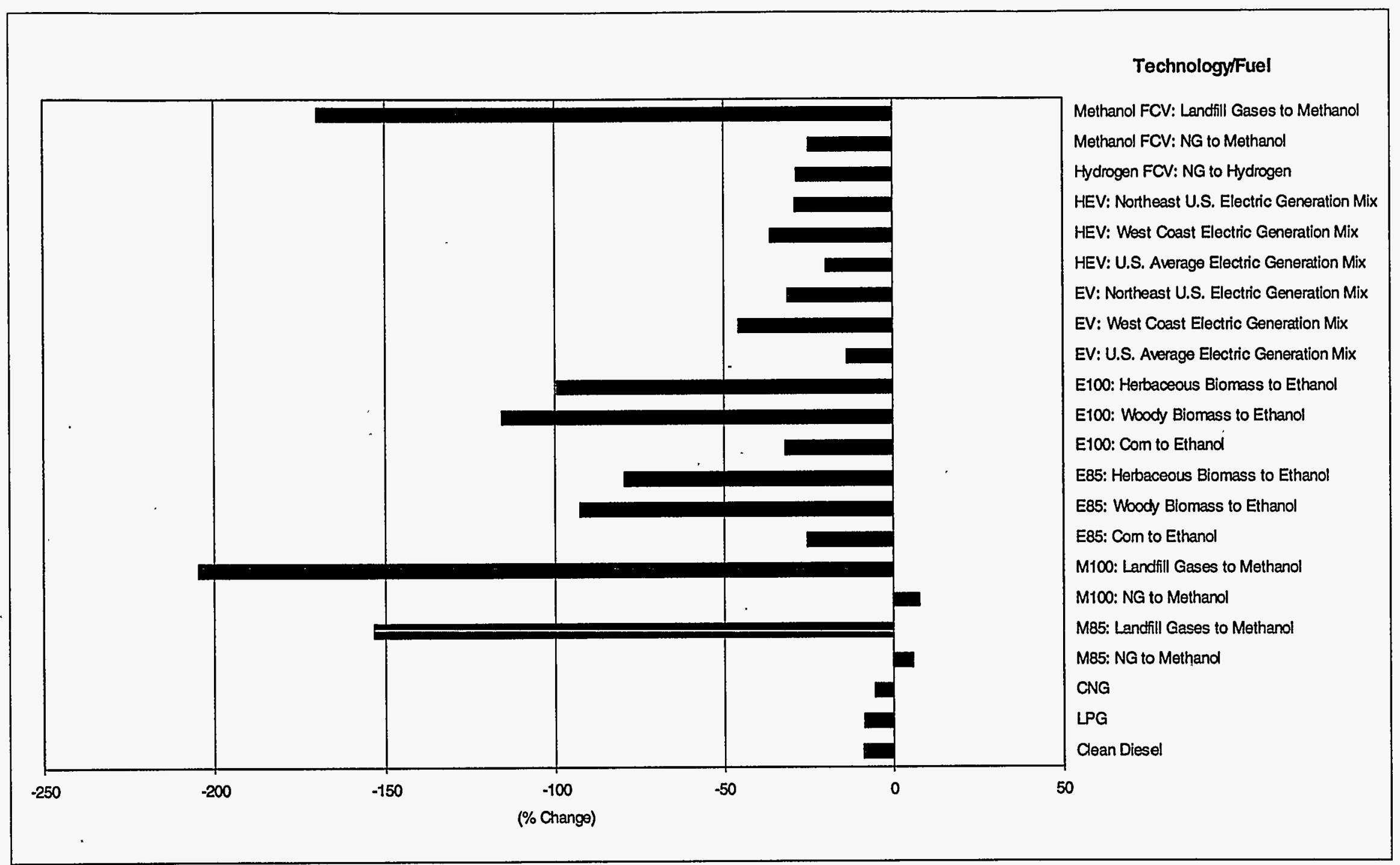

Note: The greater-than-100\% reductions for converting landfill gases to methanol are a result of eliminating the GHG emissions that would otherwise be generated by burning landfill gases directly, and those for biomass ethanol are caused by credits for the electricity produced at ethanol plants.

FIGURE 12 Change in Fuel-Cycle Greenhouse Gas Emissions (relative to RFG) 
Figure 6 shows petroleum displacement by fuel and vehicle technology. Use of each fuel and vehicle type results in reductions in petroleum use compared with the baseline GV. Except for clean diesel, these fuels or vehicle technologies achieve large reductions in petroleum use. So, using these fuels or vehicle technologies is an effective way to reduce petroleum consumption by lightduty vehicles.

Figure 7 presents changes in both all-location and in-basin VOC emissions. Use of each fuel and vehicle technology helps reduce fuel-cycle VOC emissions in all locations and in metropolitan areas. Use of FCVs, HEVs, EVs, CNG, LPG, and clean diesel results in significant VOC emission reductions. Use of EVs and hydrogen FCVs almost eliminates VOC emissions. Ethanol and methanol use achieves moderate VOC emission reductions.

Figure 8 shows that use of the subject fuels or vehicle technologies helps reduce both alllocation and in-basin fuel-cycle $\mathrm{CO}$ emissions. Hydrogen FCV and EV use almost eliminates $\mathrm{CO}$ emissions in all locations and in metropolitan areas. Use of methanol FCVs, HEVs, and clean diesel results in significant $\mathrm{CO}$ emission reductions. Use of ethanol, methanol, CNG, and LPG results in moderate $\mathrm{CO}$ emission reductions.

Figure 9 indicates that $\mathrm{NO}_{\mathrm{x}}$ emissions can decrease or increase, depending on the fuels or vehicle technologies used. Use of clean diesel causes increases in both all-location and in-basin $\mathrm{NO}_{\mathrm{x}}$ emissions. Use of herbaceous biomass-based and corn-based ethanol, methanol, CNG, and LPG causes increases in all-location $\mathrm{NO}_{\mathrm{x}}$ emissions, while use of these fuels helps reduce in-basin $\mathrm{NO}_{\mathrm{x}}$ emissions. $\mathrm{NO}_{\mathrm{x}}$ emission changes caused by using biomass-based ethanol, landfill gas-based methanol, CNG, and LPG are small. Use of FCVs, HEVs, and EVs helps reduce both all-location and in-basin $\mathrm{NO}_{\mathrm{x}}$ emissions; in-basin $\mathrm{NO}_{\mathrm{x}}$ emission reductions are higher than the all-location reductions.

Figure 10 shows a large variation in changes for fuel-cycle $\mathrm{PM}_{10}$ emissions. Use of clean diesel causes an increase of about $200 \%$ in all-location or in-basin $\mathrm{PM}_{10}$ emissions. Use of ethanol can increase all-location $\mathrm{PM}_{10}$ emissions by two to seven times, but it still results in reductions in in-basin $\mathrm{PM}_{10}$ emissions. The dramatic increases in all-location $\mathrm{PM}_{10}$ emissions by using ethanol result from the large amount of $\mathrm{PM}_{10}$ emissions generated during feedstock pretreatment and ethanol production at ethanol plants. Use of methanol, CNG, LPG, and hydrogen FCVs helps reduce both all-location and in-basin $\mathrm{PM}_{10}$ emissions. Use of HEVs and EVs results in reductions of inbasin $\mathrm{PM}_{10}$ emissions, but such use generally causes increases in all-location emissions. Use of landfill gas-based methanol results in reductions between $150 \%$ and $250 \%$; these reductions are caused by significant $\mathrm{PM}_{10}$ emissions that are generated from burning of landfill gases but are offset by methanol production.

Figure 11 shows that all-location $\mathrm{SO}_{\mathrm{x}}$ emissions are increased with the use of HEVs, EVs, and vehicles powered by corn-based ethanol and landfill gas-based methanol. However, use of these 
fuels or vehicle types still results in decreased in-basin $\mathrm{SO}_{\mathrm{x}}$ emissions. Use of FCVs, biomass-based ethanol, NG-based methanol, CNG, and LPG reduces both all-location and in-basin $\mathrm{SO}_{\mathrm{x}}$ emissions. Use of clean diesel causes increases in in-basin $\mathrm{SO}_{x}$ emissions but has little impact on all-location $\mathrm{SO}_{\mathrm{x}}$ emissions. $\mathrm{SO}_{\mathrm{x}}$ emission reductions caused by using biomass-based ethanol are a result of the electricity credit earned for biomass-ethanol plants. $\mathrm{An} \mathrm{SO}_{\mathrm{x}}$ emission credit (from the electricity credit) is calculated from the amount of electricity generated and the average $\mathrm{SO}_{\mathrm{x}}$ emissions of the U.S. electric generation mix. Because of the $\mathrm{SO}_{\mathrm{x}}$ credit, using biomass-based ethanol results in a decrease in all-location $\mathrm{SO}_{\mathrm{x}}$ emissions of greater than $100 \%$. Use of landfill gas-based methanol also results in a greater-than-100\% reduction in in-basin $\mathrm{SO}_{\mathrm{x}}$ emissions; this is a result of the emission credit for converting landfill gas to ethanol, which prevents the $\mathrm{SO}_{\mathrm{x}}$ emissions that are otherwise produced from burning landfill gases.

Figure 12 shows changes in GHG emissions as GWP-weighted emissions of $\mathrm{CO}_{2}, \mathrm{CH}_{4}$, and $\mathrm{N}_{2} \mathrm{O}$. Except for use of NG-based methanol, where GHG emissions are slightly increased, use of all fuels and vehicle technologies helps reduce $\mathrm{GHG}$ emissions. The largest reductions occur for methanol produced from landfill gases. In fact, use of landfill gas-based methanol results in 150$200 \%$ reductions in GHG emissions. These reductions are caused by the $\mathrm{CO}_{2}$ and $\mathrm{CH}_{4}$ emission credits earned by converting the landfill gas to methanol - preventing emissions that would otherwise be produced from burning landfill gases directly. Large GHG emission reductions are achieved by using FCVs, HEVs, EVs, and ethanol. Emission reductions by these fuels or vehicle types are a result of more energy-efficient vehicles and/or use of renewable feedstocks for fuel production. Use of CNG, LPG, and clean diesel results in small GHG emission reductions.

The results presented in this section rely heavily on the assumptions made in the GREET model regarding the energy efficiencies of fuel-cycle stages, emission controls for combustion technologies, vehicle fuel economy and emission performance, ratio of in-basin and out-of-basin facilities, and many other factors. Changes in these assumptions will lead to different results in fuelcycle emissions and energy use. However, the results presented here indicate general trends in relative emissions and energy uses for different fuels and vehicle types. 


\section{REFERENCES}

Acurex Environmental Corporation, 1995, Evaluation of Fuel-Cycle Emissions on a Reactivity Basis, draft 3.2, Mountain View, Calif., prepared for California Air Resources Board, El Monte, Calif., Nov. 5.

Bentley, J.M., et al., 1992, The Impact of Electric Vehicles on $\mathrm{CO}_{2}$ Emissions, Arthur D. Little, Inc., Cambridge, Mass., May 14.

Brogan, J., and S.R. Venkateswaran, 1992, "Diverse Choices for Electric and Hybrid Motor Vehicles: Implications for National Planners," presented at the Urban Electric Vehicle Conference, Stockholm, Sweden, May 25-27.

Creveling, H.F., 1992, "Research and Development of a Proton-Exchange Membrane (PEM) Fuel Cell System for Transportation Applications," Proceedings of the Annual Automotive Technology Development Contractors' Meeting, sponsored by U.S. Department of Energy, Office of Transportation Technologies, published by Society of Automotive Engineers, Warrendale, Penn., June, pp. 201-211.

Darrow, K.G., 1994a, Light-Duty Vehicle Fuel Cycle Emission Analysis, Energy International, Inc., Bellevue, Wash., prepared for Gas Research Institute, Chicago, Ill., April.

Darrow, K.G., 1994b, Comparison of Fuel-Cycle Emissions for Electric Vehicle and Ultra-Low Emissions Natural Gas Vehicle, Energy International, Inc., Bellevue, Wash., prepared for Southern California Gas Company, Los Angeles, Calif., May.

Delucchi, M.A., 1991, Emissions of Greenhouse Gases from the Use of Transportation Fuels and Electricity, Volume 1: Main Text, ANL/ESD/TM-22, Center for Transportation Research, Argonne National Laboratory, Argonne, Ill., Nov.

Delucchi, M.A., 1993, Emissions of Greenhouse Gases from the Use of Transportation Fuels and Electricity, Volume 2: Appendixes A-S, ANL/ESD/TM-22, Center for Transportation Research, Argonne National Laboratory, Argonne, Ill., Nov.

Delucchi, M.A., M.Q. Wang, and D.L. Greene, 1992, Motor Vehicle Fuel Economy, the Forgotten HC Control Strategy?, ORNL-6715, Oak Ridge National Laboratory, Oak Ridge, Tenn., June.

DOE: see U.S. Department of Energy. 
Ecotraffic, AB, 1992, Motor Fuels from Sources to Final Use, Final Report on an Energy and Emissions System Study, Stockholm, Sweden, March.

EIA: see Energy Information Administration.

Energy Information Administration, 1995, Supplement to the Annual Energy Outlook, U.S. Department of Energy, Energy Information Administration, Washington, D.C., Feb.

EPA: see U.S. Environmental Protection Agency.

General Motors Corporation, 1994, Research and Development of Proton-Exchange Membrane Fuel Cell System for Transportation Applications, Initial Conceptual Design Report, General Motors Corporation, Allison Gas Turbine Division, prepared for U.S. Department of Energy, Office of Transportation Technologies, Indianapolis, Ind., Feb.

Intergovernmental Panel on Climatic Change, 1995, IPCC Second Scientific Assessment of Climate Change: Summary for Policymakers, Draft, April 26.

IPCC: see Intergovernmental Panel on Climate Change.

Lynd, L.R., R.T. Elander, and C.E. Wyman, 1996, "Likely Features and Costs of Mature Biomass Ethanol Technology," Applied Biochemistry and Biotechnology (in press).

Marland, G., and A. F. Turhollow, 1991, " $\mathrm{CO}_{2}$ Emissions from the Production and Combustion of Fuel Ethanol from Corn," Energy, 16: 1307-1316.

Marr, W.W., 1995, User's Guide to EAGLES Version 1.1: An Electric- and Gasoline-Vehicle FuelEfficiency Software Package, ANL/ESD-27, Center for Transportation Research, Argonne National Laboratory, Argonne, Ill., Jan.

McLaughlin, S.B., 1993, "New Switchgrass Biofuels Research Program for the Southeast," Proceedings of the Annual Automotive Technology Development Contractors' Coordination Meeting 1992, published by the Society of Automotive Engineers, Warrendale, Penn., May.

National Renewable Energy Laboratory, 1992, Hydrogen Program Plan, FY 1993 - FY 1997, prepared for U.S. Department of Energy, Office of Conservation and Renewable Energy, Golden, Colo., June. 
National Renewable Energy Laboratory, Oak Ridge National Laboratory, and Pacific Northwest Laboratory, 1991, A Comparative Analysis of the Environmental Outputs of Future BiomassEthanol Production Cycles and Crude Oil/Reformulated Gasoline Production Cycles, Appendixes, prepared for U.S. Department of Energy, Office of Transportation Technologies and Office of Planning and Assessment, Golden, Colo., Dec.

National Renewable Energy Laboratory, Oak Ridge National Laboratory, and Pacific Northwest Laboratory, 1992, Fuel Cycle Evaluations of Biomass-Ethanol and Reformulated Gasoline, prepared for U.S.'Department of Energy, Office of Transportation Technologies and Office of Planning and Assessment, Golden, Colo., Oct.

NREL: see National Renewable Energy Laboratory.

NREL et al.: see National Renewable Energy Laboratory, Oak Ridge National Laboratory, and Pacific Northwest Laboratory.

Smith, J.R., 1993, "The Hydrogen Hybrid Option," presented at the Workshop in Advanced Components for Electric and Hybrid Electric Vehicles, Gaithersburg, Md., Oct. 27-28.

SCAQMD: see South Coast Air Quality Management District.

South Coast Air Quality Management District, 1994, SCAQMD Report on TeraMeth Industries' Landfill Gas Abatement Facility, Diamond Bar, Calif., Oct.

Sperling, D., and A.F. Burke, 1994, Hybrid Electric Vehicles: Always Second Best?, EPRI TR-104156, prepared for Electric Power Research Institute, Palo Alto, Calif., July.

U.S. Department of Energy, 1993, Utility Emissions Associated with Electric and Hybrid Vehicle Charging, U.S. Department of Energy, Assistant Secretary for Energy Efficiency and Renewable Energy, Office of Transportation Technologies, Electric and Hybrid Propulsion Division, Washington, D.C., April.

U.S. Environmental Protection Agency, 1991, Air Emissions from Municipal Solid Waste Landfills: Background Information for Proposed Standards and Guidelines, EPA-450/3-90-011a, Research Triangle Park, N.C.

U.S. Environmental Protection Agency, 1994, "Regulation of Fuels and Fuel Additives; Standards for Reformulated and Conventional Gasoline; Final Rule," Federal Register, 59: 7716-7878, Feb. 16. 
U.S. Environmental Protection Agency, 1995, Compilation of Air Pollutant Emission Factors, Volume 1: Stationary Point and Area Sources, AP-42, Fifth Edition, Research Triangle Park, N.C., Jan.

Wang, M.Q., and M.A. Delucchi, 1992, "Impacts of Electric Vehicles on Primary Energy Consumption and Petroleum Displacement," Energy, 17: 351-366.

Wang, M.Q., and D.J. Santini, 1993, "Magnitude and Value of Electric Vehicle Emissions Reductions for Six Driving Cycles in Four U.S. Cities with Varying Air Quality Problems," Transportation Research Record, 1416:33-42.

Wang, M.Q., D. Sperling, and J. Olmstead, 1993, "Emission Control Cost-Effectiveness of Alternative-Fuel Vehicles," SAE Technical Paper 931841, Society of Automotive Engineers 1993 Transactions: Journal of Fuels and Lubricants, 102:789-820.

Williams, E.J., A. Guenther, and F. C. Fehsenfeld, 1992, "An Inventory of Nitric Oxide Emissions from Soils in the United States," Journal of Geophysical Research, 97: 7511-7519. 
APPENDIX:

CHANGES IN ENERGY USE AND EMISSIONS BY ALTERNATTVE FUELS 
Appendix: Changes in Energy Use and Emissions by Alternative Fuels (\% relative to RFG)

\begin{tabular}{|c|c|c|c|c|c|c|c|c|c|c|c|}
\hline & $\begin{array}{l}\text { Methanol } \\
\text { FCV: } \\
\text { Landfill } \\
\text { Gases to } \\
\text { Methanol }\end{array}$ & $\begin{array}{l}\text { Methanol } \\
\text { FCV: NG } \\
\text { to } \\
\text { Methanol }\end{array}$ & $\begin{array}{l}\text { Hydrogen } \\
\text { FCV: NG } \\
\text { to } \\
\text { Hydrogen }\end{array}$ & $\begin{array}{l}\text { HEV: } \\
\text { Northeast } \\
\text { U.S. Electric } \\
\text { Generation } \\
\text { Mix }\end{array}$ & $\begin{array}{l}\text { HEV: West } \\
\text { Coast } \\
\text { Electric } \\
\text { Generation } \\
\text { Mix }\end{array}$ & $\begin{array}{l}\text { HEV: U.S. } \\
\text { Average } \\
\text { Electric } \\
\text { Generation } \\
\text { Mix }\end{array}$ & $\begin{array}{c}\text { EV: Northeast } \\
\text { U.S. Electric } \\
\text { Generation } \\
\text { Mix }\end{array}$ & $\begin{array}{l}\text { EV: West } \\
\text { Coast } \\
\text { Electric } \\
\text { Generation } \\
\text { Mix }\end{array}$ & $\begin{array}{l}\text { EV: U.S. } \\
\text { Average } \\
\text { Electric } \\
\text { Generation } \\
\text { Mix }\end{array}$ & $\begin{array}{c}\text { E100: } \\
\text { Herbaceous } \\
\text { Biomass to } \\
\text { Ethanol }\end{array}$ & $\begin{array}{c}\text { E100: } \\
\text { Woody } \\
\text { Biomass to } \\
\text { Ethanol }\end{array}$ \\
\hline Total energy & -42.2 & -14.1 & -18.6 & -26.1 & -32.4 & -26.2 & -25.2 & -37.8 & -25.4 & 17.4 & 34.5 \\
\hline Fossil fuels & -94.0 & -13.9 & -18.3 & -38.1 & -41.0 & -34.3 & -49.0 & -55.0 & -41.6 & .97 .9 & -101.8 \\
\hline Petrolcum & -100.0 & -98.0 & -97.3 & -56.0 & -61.7 & -61.4 & -84.9 & -96.5 & -95.9 & -97.3 & -97.4 \\
\hline VOC: all locations & -78.7 & -69.8 & -90.9 & -72.8 & -73.0 & -72.9 & -98.3 & -98.8 & -98.6 & -45.8 & -45.4 \\
\hline VOC: in-basin & -77.1 & -75.3 & -98.5 & -74.1 & -74.1 & -74.1 & -99.9 & -99.9 & -100.0 & -46.6 & -46.6 \\
\hline CO: all locations & -93.0 & -88.0 & -97.2 & -74.4 & -74.4 & -74.4 & -99.2 & -99.1 & -99.2 & -20.1 & -19.8 \\
\hline CO: in-basin & -91.5 & -89.8 & -99.6 & -74.9 & -74.9 & -75.0 & -99.9 & -99.9 & -99.9 & -19.9 & -19.9 \\
\hline $\mathrm{NO}_{\mathrm{x}}:$ all locations & -65.6 & -34.1 & -23.3 & -25.7 & -32.2 & -11.3 & -45.4 & -57.8 & -17.5 & 3.2 & -6.8 \\
\hline $\mathrm{NO}_{x}$ : in-basin & -83.5 & -83.2 & -87.4 & .49 .1 & -48.8 & -49.6 & -97.3 & .96 .8 & -98.3 & -7.8 & .8 .1 \\
\hline $\mathrm{PM}_{10}$ : all locations & -204.4 & -36.1 & -22.9 & 5.4 & -9.4 & 28.5 & 26.2 & -2.5 & 71.0 & 486.7 & 751.3 \\
\hline $\mathrm{PM}_{10}$ : in-basin & -160.9 & -35.8 & -29.4 & -22.2 & -23.1 & -23.6 & -36.1 & -37.7 & -38.6 & -33.9 & -34.2 \\
\hline SO $_{\mathrm{x}}$ : all locations & 17.0 & -86.5 & .91 .3 & 124.8 & 48.9 & 234.4 & 283.7 & 136.5 & 495.8 & -138.1 & -219.1 \\
\hline $\mathrm{SO}_{\mathrm{x}}$ : in-basin & -109.7 & -86.3 & -96.1 & -34.1 & -57.1 & -56.6 & -42.5 & -87.1 & -86.2 & -88.3 & -91.1 \\
\hline GHGs & -169.4 & -24.7 & -28.5 & -28.7 & -36.2 & -19.7 & -31.0 & -45.6 & -13.6 & -99.3 & -115.7 \\
\hline $\mathrm{CH}_{4}$ & -2215.4 & 446.3 & 383.8 & 259.7 & 218.5 & 453.3 & 540.1 & 457.5 & 927.2 & -39.0 & -40.1 \\
\hline $\mathrm{N}_{2} \mathrm{O}$ & 134.8 & -37.0 & -72.4 & 198.5 & 110.0 & 388.9 & 432.9 & 261.3 & 801.3 & 593.6 & . 33.0 \\
\hline $\mathrm{CO}_{2}$ & -161.6 & -27 & -30.2 & -32.2 & -38.9 & -25.9 & -38.2 & -51 & -25.9 & -106 & -117.4 \\
\hline
\end{tabular}


Appedix: Changes in Energy Use and Emissions by Alternative Fuels (\% relative to RFG) (Continued)

\begin{tabular}{|c|c|c|c|c|c|c|c|c|c|c|c|}
\hline & $\begin{array}{l}\text { E100: } \\
\text { Com to } \\
\text { Ethanol }\end{array}$ & $\begin{array}{c}\text { E85: } \\
\text { Herbaceous } \\
\text { Biomass to } \\
\text { Ethanol }\end{array}$ & $\begin{array}{c}\text { E85: } \\
\text { Woody } \\
\text { Biomass } \\
\text { to Ethanol }\end{array}$ & $\begin{array}{l}\text { E85: } \\
\text { Corn to } \\
\text { Ethanol }\end{array}$ & $\begin{array}{l}\text { M100: } \\
\text { Landfill } \\
\text { Gases to } \\
\text { Methanol }\end{array}$ & $\begin{array}{l}\text { M100: } \\
\text { NG to } \\
\text { Methanol }\end{array}$ & $\begin{array}{l}\text { M85: } \\
\text { Landfill } \\
\text { Gases to } \\
\text { Methanol }\end{array}$ & $\begin{array}{c}\text { M85: } \\
\text { NG to } \\
\text { Methanol }\end{array}$ & CNG & LPG & $\begin{array}{l}\text { Clean } \\
\text { Diesel }\end{array}$ \\
\hline \multicolumn{12}{|l|}{ • } \\
\hline Total energy & 24.7 & 17.0 & 27.6 & 30.9 & -15.2 & 25.9 & -11.7 & 19.1 & -9.0 & -9.0 & -19.2 \\
\hline Fossil fuels & -43.1 & -77.7 & -81.5 & -32.7 & -91.2 & 26.3 & -68.5 & 19.4 & -10.0 & -8.8 & -19.0 \\
\hline Petroleum & -89.3 & -77.9 & -77.9 & -71.5 & -100.0 & -97.1 & -75.1 & -72.9 & -99.8 & -83.2 & -9.4 \\
\hline VOC: all locations & -39.0 & -41.3 & -40.9 & -35.8 & -52.0 & -38.9 & -45.7 & -36.0 & -79.4 & -72.8 & -62.2 \\
\hline VOC: in-basin & -46.6 & -42.1 & -42.1 & -42.1 & -48.7 & -46.1 & -43.7 & -41.7 & -80.1 & -74.9 & -63.0 \\
\hline CO: all locations & -14.2 & -15.1 & -14.9 & -10.3 & -25.5 & -18.2 & -19.2 & -13.7 & -40.1 & -29.9 & -86.3 \\
\hline CO: in-basin & -19.9 & -14.9 & -14.9 & -14.9 & -22.2 & -19.8 & -16.7 & -14.8 & -40.0 & -30.0 & -87.3 \\
\hline $\mathrm{NO}_{\mathrm{x}}$ : all locations & 98.3 & 4.9 & -3.0 & 81.1 & 11.3 & 57.6 & 10.4 & 45.0 & 4.7 & 2.0 & 57.8 \\
\hline $\mathrm{NO}_{\mathrm{x}}$ : in-basin & -7.4 & -3.3 & -3.6 & -3.0 & -2.9 & -2.5 & 0.2 & 0.6 & -6.8 & -3.8 & 78.2 \\
\hline $\mathrm{PM}_{10}$ : all locations & 322.3 & 386.8 & 598.4 & 255.3 & -272.7 & -25.9 & -207.7 & -23.1 & -34.4 & -42.1 & 157.8 \\
\hline $\mathrm{PM}_{10}$ : in-basin & -33.5 & -30.5 & -30.8 & -30.2 & -217.1 & -33.7 & -167.6 & -30.4 & -39.7 & -35.5 & 247.5 \\
\hline SO: all locations & 459.6 & -110.5 & -175.2 & 367.5 & 71.6 & -80.3 & 53.3 & -60.3 & -0.1 & -80.6 & -0.2 \\
\hline SO $_{\mathrm{x}}$ : in-basin & -84.7 & -70.6 & -72.9 & -67.8 & -114.3 & -80.0 & -85.7 & -60.1 & -93.3 & -94.7 & 214.4 \\
\hline GHGs & -31.7 & -79.3 & -92.4 & -25.4 & -204.5 & 7.9 & -153.1 & 5.7 & -5.5 & -8.3 & -8.6 \\
\hline $\mathrm{CH}_{4}$ & 15.0 & -26.7 & -27.5 & 16.5 & -3157.0 & 746.8 & -2359.1 & 560.7 & 2377.8 & 557.9 & -84.8 \\
\hline $\mathrm{N}_{2} \mathrm{O}$ & 3577.8 & 474.7 & 26.3 & 2861.4 & 237.8 & -14.2 & 177.7 & -10.8 & 96.1 & -31.4 & -25.2 \\
\hline $\mathrm{CO}_{2}$ & -64.8 & -84.7 & -93.9 & -51.9 & -193.2 & 4.2 & -144.7 & 2.9 & -18.7 & -11.0 & -8.1 \\
\hline
\end{tabular}




\section{DISTRIBUTION FOR ANL/ESD-33}

Internal

ANL Publications and Record Services

R. Weeks

L. Welko (5)

M. Fitzpatrick

M. Wang (200)

\section{External}

U.S. Department of Energy, Office of Scientific and Technical Information (12)

Manager, U.S. Department of Energy, Chicago Field Office

ANL-E Libraries

ANL-W Library 